Barker, N. K. S., S. G. Cumming, and M. Darveau. 2014. Models to predict the distribution and abundance of breeding ducks in Canada. Avian Conservation and Ecology 9(2): 7. http://dx.doi.org/10.5751/ACE-00699-090207

Copyright (C) 2014 by the author(s). Published here under license by the Resilience Alliance.

Research Paper

\title{
Models to predict the distribution and abundance of breeding ducks in Canada
}

\author{
Nicole K. S. Barker ${ }^{1,2}$, Steven G. Cumming ${ }^{1}$ and Marcel Darveau ${ }^{2}$ \\ ${ }^{1}$ Département des sciences du bois et de la forêt, Université Laval, ${ }^{2}$ Ducks Unlimited Canada
}

\begin{abstract}
Detailed knowledge of waterfowl abundance and distribution across Canada is lacking, which limits our ability to effectively conserve and manage their populations. We used 15 years of data from an aerial transect survey to model the abundance of 17 species or species groups of ducks within southern and boreal Canada. We included 78 climatic, hydrological, and landscape variables in Boosted Regression Tree models, allowing flexible response curves and multiway interactions among variables. We assessed predictive performance of the models using four metrics and calculated uncertainty as the coefficient of variation of predictions across 20 replicate models. Maps of predicted relative abundance were generated from resulting models, and they largely match spatial patterns evident in the transect data. We observed two main distribution patterns: a concentrated prairie-parkland distribution and a more dispersed pan-Canadian distribution. These patterns were congruent with the relative importance of predictor variables and model evaluation statistics among the two groups of distributions. Most species had a hydrological variable as the most important predictor, although the specific hydrological variable differed somewhat among species. In some cases, important variables had clear ecological interpretations, but in some instances, e.g., topographic roughness, they may simply reflect chance correlations between species distributions and environmental variables identified by the model-building process. Given the performance of our models, we suggest that the resulting prediction maps can be used in future research and to guide conservation activities, particularly within the bounds of the survey area.
\end{abstract}

\section{Des modèles pour prédire la répartition et l'abondance des canards nichant au Canada}

RÉSUMÉ. Le manque de connaissances détaillées sur l'abondance et la répartition des espèces de sauvagine dans l'ensemble du Canada limite notre capacité à conserver et à gérer leurs populations de façon efficace. Au moyen de 15 années de données provenant d'inventaires aériens réalisés par transects, nous avons modélisé l'abondance de 17 espèces ou groupes d'espèces de canards dans les parties méridionale et boréale du Canada. Nous avons inclus 78 variables relatives au climat, à l'hydrologie et au paysage dans des modèles amplifiés d'arbres de régression, pour lesquels des courbes de réponse flexibles et les interactions multidimensionnelles entre les variables ont pu être examinées. Nous avons évalué la capacité de prédiction des modèles à l'aide de quatre paramètres et avons estimé l'incertitude en calculant le coefficient de variation des prédictions d'un jeu de 20 répétitions de modèles. Des cartes de l'abondance relative prédite ont été produites à partir des modèles et elles correspondent bien au profil spatial des données récoltées dans les transects. Nous avons observé deux tendances principales dans la répartition : l'une centrée sur les Prairies et les forêts-parcs, l'autre plus dispersée à la grandeur du Canada. Ces tendances coïncidaient avec l'importance relative des variables explicatives et les statistiques d'évaluation des modèles pour les deux groupes de répartition. Les variables qui expliquaient le mieux la répartition de la majorité des espèces avaient trait à l'hydrologie, bien que plus spécifiquement, elles différaient quelque peu d'une espèce à l'autre. Pour certaines variables importantes d'après les modèles, nous avons pu établir des liens clairs entre celles-ci et la répartition des espèces, tandis que pour d'autres, par exemple l'irrégularité du relief, nous pensons qu'elles pourraient simplement être le fruit de corrélations, attribuables au hasard, entre la répartition des espèces et les variables environnementales retenues lors du processus de consolidation des modèles. Considérant les performances de nos modèles, nous proposons que les cartes de répartition prédite soient utilisées dans le cadre de recherches futures et à des fins d'orientation des activités de conservation, surtout à l'intérieur des limites de notre aire d'étude.

Key Words: abundance; Boosted Regression Tree; Canada; distribution; ducks; habitat; North America; species distribution model; waterfowl

\section{INTRODUCTION}

Species distribution models (SDMs) provide quantitative descriptions of species' distributions based on associations between observational data and environmental predictors (Guisan and Zimmermann 2000, Elith and Leathwick 2009a). SDMs built with count data, called species abundance models (SAMs), quantify indices of abundance or density rather than occurrence (Elith and Leathwick 2009a). Given suitable predictors, SDMs and SAMs can identify key habitat factors for species of interest (Milsom et al. 2000, Morrison et al. 2006), providing insight on autecology and informing conservation decisions. Predictive maps generated from these models provide basic information on species distribution and abundance (Guisan and Zimmermann 2000, Austin 2002). These maps can be used 
to improve species range delineation (Loiselle et al. 2003), to test biogeographical hypotheses (Leathwick 1998, Anderson et al. 2002), to inform conservation strategies (Ferrier 2002, OrtegaHuerta and Peterson 2004, Moilanen et al. 2005, Elith and Leathwick 2009b), and to predict population responses to climate and land use change (Araújo et al. 2004, Thuiller 2004, Jetz et al. 2007). The focus of this paper is on SAMs for breeding waterfowl in boreal and southern Canada.

The urgency of conservation challenges in the Canadian boreal forest is increasingly recognized (Schindler and Lee 2010, Badiou et al. 2013, Berteaux 2013). To meet these challenges, we must quantify species abundances, distributions, and habitat relationships to target locations for conservation and identify the conflicts between wildlife habitat and intensive human activities (Slattery et al. 2011). The predictive maps generated through SDMs and SAMs may be particularly useful for these purposes in remote or unsurveyed areas, such as much of the boreal regions of northern Canada. A number of such studies are now under way, directed at boreal forest songbirds (Cumming et al. 2014), and waterfowl in eastern Canada (Lemelin et al. 2010, Börger and Nudds 2014) and western Canada (L. Armstrong, J. Devries, D. Howerter, B. Kazmerik, A. Richard, S. Slattery, and B. Tedford, unpublished report; Ducks Unlimited Canada, unpublished report). However, there has been no attempt to model the abundance of individual waterfowl species at national levels.

The lack of national waterfowl distribution models is surprising given the existence of an extensive and long-term aerial survey, the Waterfowl Breeding Population and Habitat Survey (WBPHS; Smith 1995). Each May since 1955, the U.S. Fish and Wildlife Service (USFWS) and Canadian Wildlife Service (CWS) survey much of the breeding distributions of many waterfowl species (Fig. 1). The survey has created a large data set on individual species' abundances; this information was collected using relatively consistent sampling methods and survey design. The survey was originally designed to provide annual estimates of total duck population to inform hunting regulation (Nichols et al. 1995), although a substantial body of secondary research exists.

Some secondary applications exploit the survey's time series to model population dynamics, exploring relationships between population size and wetland availability, adult survival, annual productivity, and climate change (Pospahala et al. 1974, Anderson 1975, Johnson and Shaffer 1987, Kaminski and Gluesing 1987, Raveling and Heitmeyer 1989, Podruzny et al. 2002, Drever et al. 2012). More recently, the data set has been used to test new methodological approaches (Jamieson and Brooks 2004, Gimenez et al. 2009, Ross et al. 2012, Lawrence et al. 2013). However, there have been only limited attempts to use these data in predicting species distribution and abundance over large areas. Species abundance patterns have been mapped for several species at low spatial resolution (Johnson and Grier 1988). Annual abundances were correlated with the number of available wetlands (Johnson and Grier 1988), but only for regions with annual pond counts. Spatial interpolation of survey data has been used to predict abundances of Scaup (Aythya affinis, Aythya marila) pairs across their range (Hobson et al. 2009). However, no SAMs and their derived predictive abundance maps have been published for any waterfowl species at national extent.
Fig. 1. Top: Survey strata and transects of the Waterfowl Breeding Population and Habitat Survey (WBPHS) in Canada. Bottom: Some major lakes, rivers, and ecoregions referred to herein. The orange colors depict the four ecoregions of the prairie-parkland. References to "prairies" denote the northwestern glaciated plains if confined to Canada, or the union of the two plains ecoregions when including the USA. We split the boreal region (Brandt 2009) along the OntarioManitoba border to facilitate discussion of regional variation in waterfowl abundances.
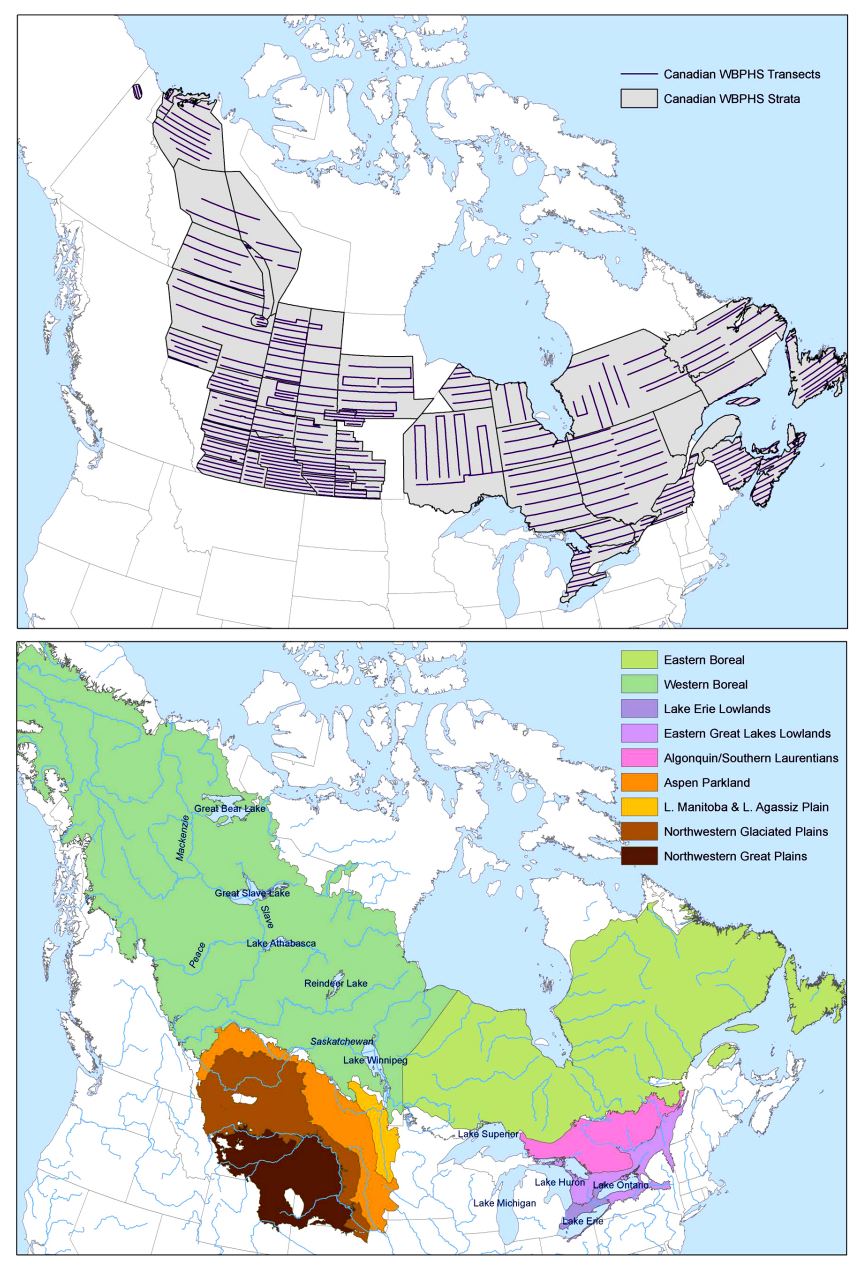

We used the WBPHS database to develop high spatial resolution, predictive SAMs for 17 waterfowl species or species groups. Our modeling methodology was Boosted Regression Trees (BRTs) with a library of 78 environmental predictor variables selected a priori for their biological or physical effects on waterfowl species. We used the models to develop predictive relative abundance maps for most of Canada, excluding tundra areas where certain hydrological covariates were not available. In this paper, we present an evaluation of the models in terms of their predictive power and bias. We summarize the importance of different classes of environmental covariates: climatic, bioclimatic, hydrological, and landscape, and informally examine whether their relative importances differ by feeding or nesting habit. 
Table 1. Species and species groups included in this study, along with the feeding and nesting guild assigned to each. Guild classifications are based on Bellrose (1980) and Johnsgard (2010).

\begin{tabular}{|c|c|c|c|c|}
\hline Abbreviation & Common Name & Scientific Name & $\begin{array}{l}\text { Feeding } \\
\text { Guild }\end{array}$ & $\begin{array}{l}\text { Nesting } \\
\text { Guild }\end{array}$ \\
\hline ABDU & American Black Duck & Anas rubripes & Dabbling & Ground \\
\hline AGWT & Green-winged Teal & Anas crecca & Dabbling & Ground \\
\hline AMWI & American Wigeon & Anas americana & Dabbling & Ground \\
\hline BWTE & Blue-winged Teal & Anas discors & Dabbling & Ground \\
\hline GADW & Gadwall & Anas strepera & Dabbling & Ground \\
\hline MALL & Mallard & Anas platyrhynchos & Dabbling & Ground \\
\hline NOPI & Northern Pintail & Anas acuta & Dabbling & Ground \\
\hline NSHO & Northern Shoveler & Anas clypeata & Dabbling & Ground \\
\hline BUFF & Bufflehead & Bucephala albeola & Diving & Cavity \\
\hline GGOL & Goldeneye species & $\begin{array}{l}\text { Bucephala clangula } \\
\text { Bucephala islandica }\end{array}$ & Diving & Cavity \\
\hline GMER & Merganser species & $\begin{array}{l}\text { Mergus merganser } \\
\text { Mergus serrator } \\
\text { Lophodytes cucullatus }\end{array}$ & Diving & Cavity \\
\hline GSCO & Scoter species & $\begin{array}{l}\text { Melanitta americana } \\
\text { Melanitta fusca } \\
\text { Melanitta perspicillata }\end{array}$ & Diving & Ground \\
\hline CANV & Canvasback & Aythya valisineria & Diving & Over-water \\
\hline REDH & Redhead & Aythya americana & Diving & Over-water \\
\hline RNDU & Ring-necked Duck & Aythya collaris & Diving & Over-water \\
\hline RUDU & Ruddy Duck & Oxyura jamaicensis & Diving & Over-water \\
\hline GSCA & Scaup species & $\begin{array}{l}\text { Aythya affinis } \\
\text { Aythya marila }\end{array}$ & Diving & Over-water \\
\hline
\end{tabular}

\section{METHODS}

\section{Waterfowl population data}

We obtained waterfowl count data from the WBPHS (Smith 1995). Observers count adults of common waterfowl species seen within $200 \mathrm{~m}$ of fixed-wing aircraft flight transects. Within transects, counts are spatially assigned to segments of about 28.8 $\mathrm{km}$ (by $0.4-\mathrm{km}$ width for a segment area of $11.2 \mathrm{~km}^{2}$ ). For details on survey methodology see Smith 1995, U.S. Fish and Wildlife Service 2012, and Zimmerman et al. 2012.

We modeled segment-level counts of total indicated pairs from the Canadian portion of the WBPHS survey area (2273 segments; Fig. 1). Total indicated pairs are an estimate of the number of pairs present based on the raw counts of actual pairs and lone males detected, taking into account species-specific life history (Dzubin 1969, Smith 1995, U.S. Fish and Wildlife Service 2012). We used 15 years of data from 1995 to 2010; data from 2007 were excluded because of a deviation in that year from the usual survey design (Silverman 2011). We used this temporal subset to capture a relatively static, recent, and representative sample of waterfowl counts.

We created 17 species abundance models, 13 for individual species and 4 for species that are grouped within the survey protocol (Table 1): Goldeneye (Bucephala clangula, Bucephala islandica), Merganser (Mergus merganser, Mergus serrator, Lophodytes cucullatus), Scoter (Melanitta americana, Melanitta fusca, Melanitta perspicillata), and Scaup. These four groups are referred to as species hereafter. To explore how characteristics of fitted models might vary with life history, species were assigned feeding and nesting guilds (Table 1) following Bellrose 1980 and
Johnsgard 2010. We classified the Merganser group as cavity nesting, despite the Red-breasted Merganser being a ground nester (Titman 1999), to reflect the more specialized nesting habit of the other two species in the group.

\section{Environmental data}

We selected environmental predictor variables based on previous studies of waterfowl habitat selection (Horn et al. 2005, Paszkowski and Tonn 2006, Suhonen et al. 2011) and songbird distribution (Cumming et al. 2014, Stralberg et al. 2014). Selection criteria included a priori hypotheses on likely ecological relationships (Mac Nally 2000, Barry and Elith 2006, Wenger and Olden 2012), constrained by availability and coverage. Where possible, we prioritized variables with more direct and likely causal relationships with waterfowl abundance, although proxy or indirect variables (Austin 2002) were used in many cases. We used a total of 78 climatic, bioclimatic, landscape, and hydrological predictor variables (Appendix 1).

Annual climatic variables and most bioclimatic indices were extracted from interpolated weather station data provided by Natural Resources Canada (McKenney et al. 2011). We calculated 30-year means of maximum and minimum monthly temperature, summarized to season, to capture potential temperature limits imposed on waterfowl abundance through vegetation, invertebrate phenology, and other seasonal influences (Appendix 1). We calculated 30 -year means of total monthly precipitation, summarized to season, to capture the influence of precipitation through wetland conditions. We calculated 30-year standard deviations of monthly maximum temperature, minimum temperature, and precipitation as proxies for the probabilities of extreme events (Cumming et al. 2014, Lynch et al. 2014) Thirty- 
year means of bioclimatic variables capture effects of seasonality in temperature and precipitation, the duration of the breeding season, and other factors (Appendix 1). Gross primary productivity was included as a proxy for food availability, both directly as plant food and indirectly through the provision of food for invertebrate prey.

We included variables for land cover to capture the influence of upland vegetation on waterfowl abundance and distribution, using the 250-m resolution Land Cover Map of Canada (Canada Centre for Remote Sensing 2008). The original 39 land cover classes were reclassified to 16 (Appendix 2). Proportional class areas were calculated per segment. Shannon's diversity index was calculated from these land cover proportions as an index of habitat heterogeneity. Topographic ruggedness (Integrated Remote Sensing Studio 2010) was included to represent the influence of landform or terrain.

To measure the type and abundance of surface waters, we used Ducks Unlimited Canada's Hybrid Wetland Layer (N. Jones, unpublished report) to calculate the proportional area of wetlands, including swamps, marshes, bogs, and fens, and open water, including shallow open water and deeper water systems, in each segment. Shoreline length and complexity, stream length, and the density and mean size of water bodies were measured from the National Hydrology Network product (Appendix 1; Natural Resources Canada 2007). These variables were included to represent influences of size, depth, and shape of wetlands as surrogates for availability of different foods for waterfowl.

All environmental variables were measured over a 1-km buffer around each segment, to account for imprecision in survey flight lines among years and to capture the influence of local environmental conditions. Spatial analysis relied on the integration of raster and vector data in PostGIS 2.0 (Obe and Hsu 2011).

\section{Statistical methods}

We built SAMs using BRTs, a machine learning technique that combines the advantages of decision-tree analyses with boosting and bagging algorithms to improve predictive performance (Friedman et al. 2000, Friedman 2002). BRTs have several advantages: they detect important relationships from large sets of predictor variables; they accommodate the complex, nonlinear relationships that often exist between species and habitat (Gaston 2003); they accommodate multiway interactions among predictor variables; they are insensitive to outliers and transformations of the predictor variables (Elith et al. 2008); and they show good predictive performance (Elith et al. 2006, 2008, Oppel et al. 2012).

We assumed that the annual counts of waterfowl pairs per segment were independent Poisson random variables conditional on the environmental predictors. We used BRT models with Poisson error and logarithmic link. The response variable was segmentlevel total indicated pairs. Because segments were surveyed for variable numbers of years, we summed total indicated pairs over all years sampled and included $\log$ (years sampled) as an offset. Under the Poisson assumptions, this correctly accounts for variation in sampling effort among segments (Sólymos et al. 2013, Cumming et al. 2014). The model-fitted values and predictions were interpreted as the expected annual abundance in a segment.
To fit models, perform cross-validation analyses, and derive predictions, we used the dismo (Hijmans et al. 2012) and gbm (Ridgeway 2013) packages, running under R 2.15.2 (R Core Team 2012).

Within BRTs, user-selected parameters and constraints customize the complexity of the trees to prevent the overfitting that is common in simpler tree methods such as classification and regression trees (Guisan and Zimmermann 2000, Elith et al. 2008). The tree complexity parameter controls the number of permitted interactions among predictor variables (Elith et al. 2008). Based on preliminary analysis of model performance, we set the tree complexity parameter to four as representing a reasonable trade-off between flexibility and overfitting. Learning rates necessary to obtain approximately 1000 trees using a 10 -fold cross-validation procedure detailed by Elith et al. 2008 varied among species, ranging from 0.015 for the Ruddy Duck (Oxyura jamaicensis) to 0.65 for the Mallard (Anas platyrhynchos).

We assessed the predictive performance of our models using repeated random subsampling cross-validation (Lu et al. 2011, section 10.6.1). We built 20 replicate BRT models for each species, using independent random samples of $70 \%$ of the segments $(n=$ 1591). Model predictive performance was assessed by comparing predictions with observations for the remaining segments $(\mathrm{n}=$ 682). For each replicate model, we calculated four evaluation statistics. The first two statistics were the estimated intercepts and slopes of linear regression models of predictions against observations. The intercept measures the magnitude and direction of bias, with values close to 0 indicating low or no bias. The slope yields information about the consistency in the bias as a function of the mean, with a value of 1 indicating a consistent bias if the intercept is a nonzero value. The third statistic is Spearman's rank correlation, which measures overall consistency of predictions and observations. Finally, the squared deviance explained, $\mathrm{D}^{2}$, is the Poisson equivalent to the Normal $\mathrm{R}^{2}$ and quantifies the goodness of fit. Spatial autocorrelation was assessed by comparing Moran's I calculated using residuals from BRT models with that calculated using residuals of a null model including only the mean. We calculated residual autocorrelation at two scales: the segment and the transect (see Appendix 3 for details). At each scale, we report statistics for both null model and BRT model residuals and their ratio. The ratio measures the degree to which the BRTs reduce spatial autocorrelation by conditioning on the covariates.

We mapped predicted pair abundance by applying BRT models to environmental variables, resampled to a consistent projection, i.e., geographic North American Datum 1983, on a 300-arcsecond grid. Cell areas over the prediction zone ranged from 27.9 to 68.1 $\mathrm{km}^{2}$. Predicted values were the expected pair abundance within a representative 11.2- $\mathrm{km}^{2}$ section of each grid cell, conditional on the values of environmental predictors within the cell. For mapping and statistical comparison, these values were scaled to densities of pairs per square kilometer. Maps of species' abundances show means over 20 model replicates. We mapped prediction uncertainty as the coefficient of variation in density over the 20 replicates. This measure is independent of the mean and provides information on variability in the predictions resulting from particular data subsets and subsequent contributions of different environmental predictor variables. 
We evaluated patterns of relative importance of different classes of predictor variables across feeding and nesting guilds. The relative importance of a predictor represents its influence within the model based on how often it is selected for splitting a tree, combined with how much it improves the model as a result of the split, averaged over all trees (Friedman 2001, Friedman and Meulman 2003, Elith et al. 2008). Relative importance was calculated for all predictor variables in a BRT model using formulas within the gbm package (Elith et al. 2008, Ridgeway 2013). For each predictor and each species, we calculated the mean \pm 1 SD relative importance over the 20 BRT replicates. One caution in examining these models in terms of variable importance is that complex, nonlinear responses are permitted within BRTs. Therefore, simply examining variable importance only captures one element of the results.

To understand patterns in variable importance across species, we identified the class (Appendix 1) of the most influential variable across all species, and for each feeding and nesting guild. We also calculated the cumulative relative importance for each variable class across all species and for each feeding and nesting guild.

\section{RESULTS}

\section{Model evaluation}

Overall, models performed well. Across all species, mean \pm SD was $0.78 \pm 0.09$ for Spearman's rank coefficient and $0.75 \pm 0.13$ for $\mathrm{D}^{2}$, indicating good correspondence between predictions and observations. Model calibration metrics indicated little bias in the predictions. A mean \pm SD slope of $0.94 \pm 0.03$ and an intercept of $0.17 \pm 0.08$ across all species suggest slightly positively biased predictions, with slightly greater overprediction at low abundances. There was some variability in evaluation metrics among species and guilds (Fig. 2), indicating that models were better for some species than others. The residuals of 13 out of 17 species exhibited significant $(\mathrm{p}<0.05)$ spatial autocorrelation at either the segment or transect scale (Appendix 3). Null ratios were much larger than 1 in all cases, indicating that the BRT models removed most of the spatial autocorrelation. The magnitude of Moran's $I$ was generally higher at the segment scale that at the transect scale.

Most species had the lowest prediction uncertainty in the prairieparkland region (Appendix 4), where the density of WBPHS transects is highest. Notable exceptions were the Canvasback (Aythya valisineria) and Redhead (Aythya americana), which showed localized areas of high uncertainty in western Ontario and eastern Manitoba (Appendix 4). The Ruddy Duck showed high uncertainty at the northern limits of the survey area and along the St. Lawrence water way (Appendix 4).

The mean coefficient of variation across all 17 species indicated that the highest uncertainty occurred in the Yukon, and along parts of the Pacific, northern, and Atlantic coasts (Fig. 3). Localized areas of high uncertainty also were scattered throughout the prediction area. These were mostly outside the area covered by the WBPHS (Fig. 1), especially in the tundra or western cordillera. Within the survey area, areas of localized high uncertainty were associated with large lakes or, as in northern Québec, with hydroelectric reservoirs.
Fig. 2. Evaluation metrics calculated from repeated subsample cross-validation, showing all 20 replicate Boosted Regression Tree (BRT) models for each species. Intensity of color represents overlapping of points from model replicates. Spearman and $\mathrm{D}^{2}$ measure concordance between predictions and observations, and the amount of variance explained by the model, respectively. The slope and intercept are model calibration metrics related to the presence and consistency of bias. Refer to Table 1 for species abbreviations.

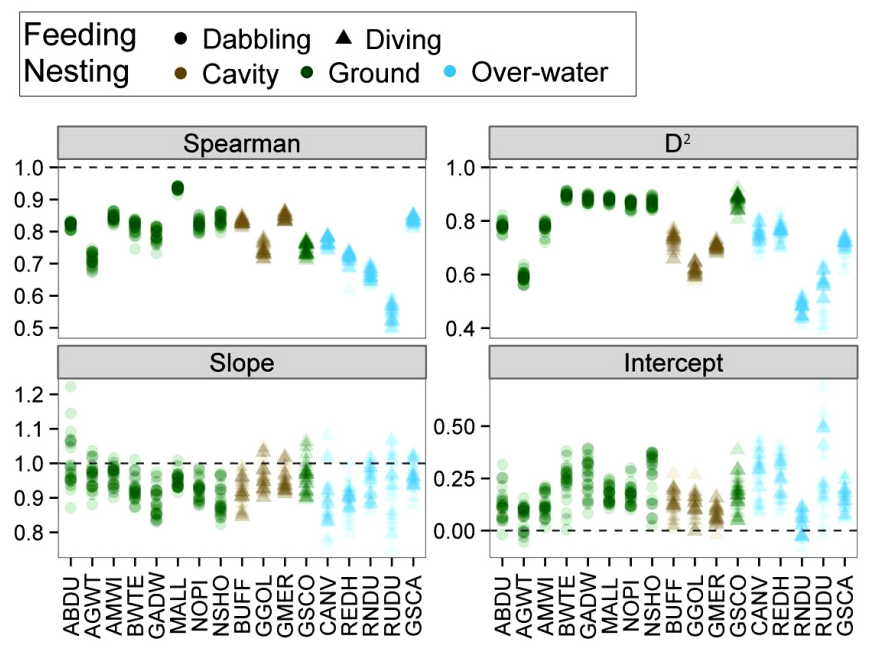

Fig. 3. Mean prediction uncertainty across 17 species models. Species-level uncertainty calculated as coefficient of variation of predicted abundance across 20 replicate Boosted Regression Tree (BRT) models. The blue outline shows the limits of the survey area (see Fig. 1).

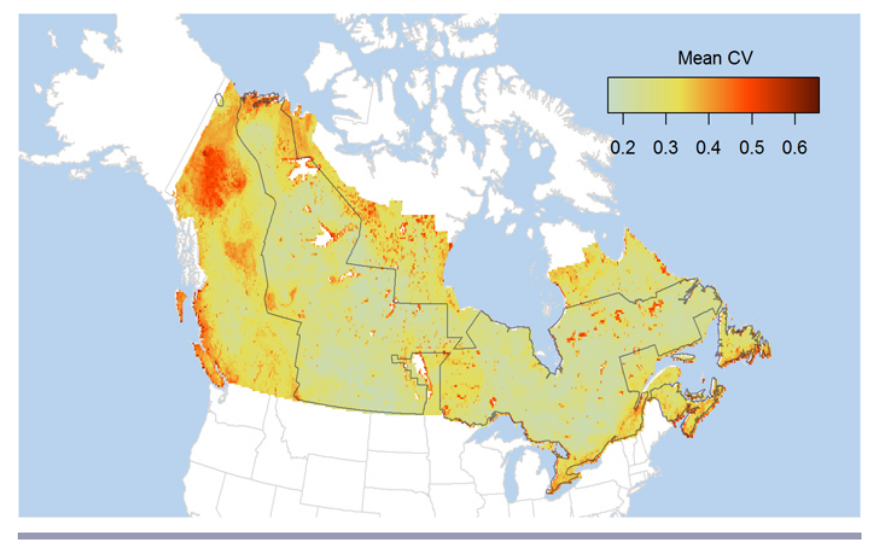

\section{Species abundance patterns}

The highest total waterfowl density was predicted to occur in the prairie-parkland region (Fig. 4), and in scattered areas throughout the western boreal, including the MacKenzie River Delta, the unsurveyed southwestern Yukon, the Peace-Athabasca Parklands, the Athabasca River Delta, and the Saskatchewan River Delta. Within the survey area, total predicted densities were 
lower in the eastern than in the western regions. The lowest total predicted densities occurred in the unsurveyed western cordillera, between the Pacific Ocean and the Rocky Mountains, and the Atlantic coastal areas.

Fig. 4. Summed relative abundances $\left(\right.$ per $\mathrm{km}^{2}$ ) of all 17 species or species groups. The prediction zone is limited by the area for which we had environmental data. The blue outline shows the limits of the survey area (see Fig. 1).

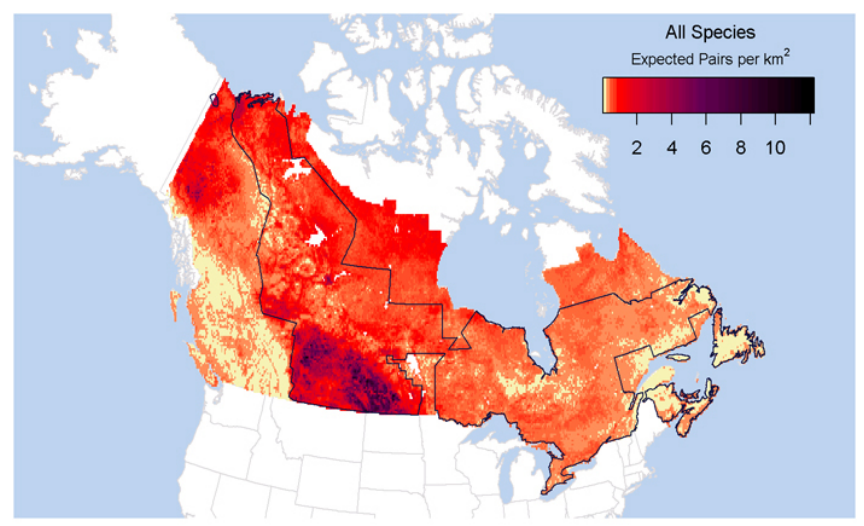

Within the WBPHS survey area, predictions of species' density from BRT analyses closely resembled spatial patterns in the raw observations (Appendix 4). Maximum raw densities exceeded maximum predicted densities for nine species (Green-winged Teal [Anas crecca], Blue-winged Teal [Anas discors], Goldeneye spp., Merganser spp., American Black Duck [Anas rubripes], American Wigeon [Anas americana], Canvasback, Redhead, and Scaup spp.), whereas the opposite was true for two species (Gadwall [Anas strepera] and Scoter spp.). Maximum densities were similar between observations and predictions for the remaining six species. The preponderance of underpredictions at high densities is consistent with mean model calibration slopes being less than 1.0 for all but one species (Fig. 2).

Ground-nesting dabbling species tended to have highest predicted densities in the prairie-parkland (Appendix 4). Exceptions include the American Black Duck, the Mallard, and the Green-winged Teal. The American Black Duck was predicted to occur across the entire eastern portion of our study area, including the boreal, Laurentians, and lowlands. It was predicted to occur at comparable densities on the west coast and in the southern interior of British Columbia. In addition to the prairie-parkland region, the Mallard was predicted to occur in most of the western boreal and the Laurentians and lowlands of Ontario. The Greenwinged Teal was predicted to occur at low densities throughout nearly the entire study area. Predicted densities of American Wigeon, Northern Pintail (Anas acuta), and Northern Shoveler (Anas clypeata) were highest in the prairie-parkland region, but substantial abundances were also predicted in parts of the western boreal, including the northern limits of the region.

Cavity-nesting diving ducks were predicted to occur at low densities over most of our study area, excluding the prairies (Appendix 4). The Bufflehead (Bucephala albeola) had the most restricted distribution, covering most of the western boreal and the aspen parkland, but was rare or absent in the eastern half of the study area. The Merganser group had the broadest predicted spatial distribution, occurring almost everywhere except the prairie region, with highest overall predicted abundances occurring in forested areas of Saskatchewan and the eastern boreal. The Goldeneye group showed a pattern similar to that of Mergansers, except for occurring at apparently lower abundances within the lowlands along the St. Lawrence River. The single ground-nesting diving species, the Scoter group, was predicted in highest densities along the northern limit of our study area, covering much of the northern boreal, including the unsurveyed Yukon (Appendix 4).

Overwater-nesting diving ducks tended to have high predicted densities in the prairie-parkland region, particularly in the aspen parkland (Appendix 4). Exceptions included the Ring-necked Duck (Aythya collaris), which according to the model, is very broadly distributed at low densities, and the Scaup group, which was predicted to occur over much of the western boreal and the northern portion of the eastern boreal in addition to the prairieparkland region.

\section{Habitat associations}

The most important single variable within models was most frequently hydrological. Hydrological variables were selected more frequently than expected given their representation within the predictor set (Fig. 5). The next most important class was landscape variables, followed by climatic variables. Bioclimatic variables were never the most influential variable. Overwaternesting ducks never had climatic variables as the top variable. None of the cavity nesters had landscape variables as the top variable.

Fig. 5. The number of species with each variable class as the most influential variable, expressed as a proportion of the number of species in the full species set or each feeding/nesting guild. Background shading represents the proportion of each variable class in the predictor dataset of 78 variables. Hydrological and landscape variables were most commonly the top variable, despite comprising a small proportion of the predictor dataset.

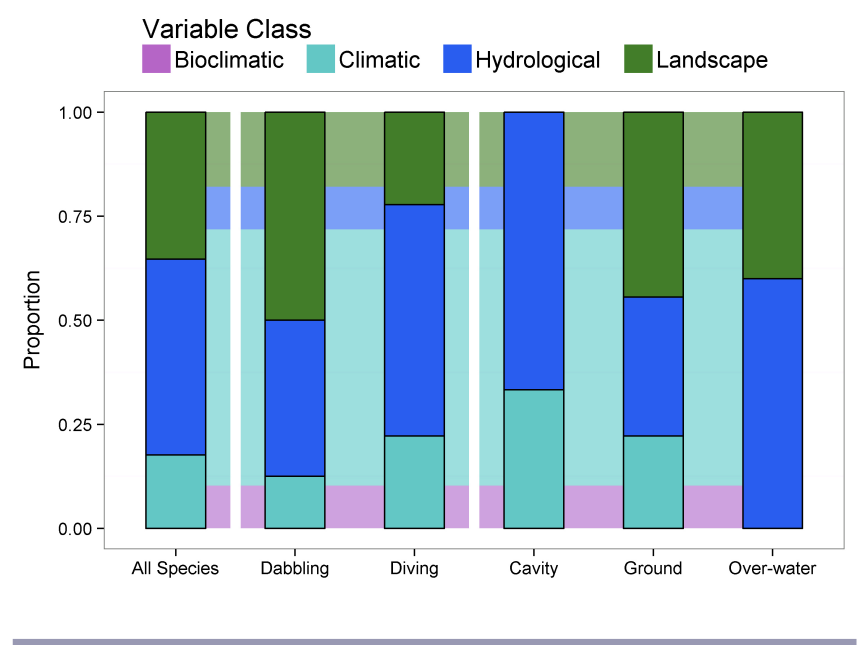


Within variable classes, some specific variables were frequently important across species. The proportion of open water was most commonly the top hydrological variable, being most important for five out of eight species (Appendix 4), followed by climate moisture index, which was most important for three out of eight species. Proportion of cropland was the top variable for four out of six species. The other top variables were each represented by only a single species (Appendix 4).

Across all species, the class total of variable relative influence was highest for climatic variables, followed by hydrological, landscape, and lastly bioclimatic variables (Fig. 6). This was also the case for all nesting and feeding guilds. For all species and among all guilds, hydrological variables had a disproportionately large share of influence given the number of variables in each class (Fig. 6). Species-specific tables of variable relative importances are presented in Appendix 4.

Fig. 6. The cumulative relative influence of each class, for the full species set, and for each feeding/nesting guild. Background shading represents the proportion of each variable class in the predictor dataset of 78 variables. Climatic variables had the highest total relative influence, while hydrological variables contributed a disproportionately high cumulative influence relative to their contribution to the predictor dataset ( 8 out of 78).

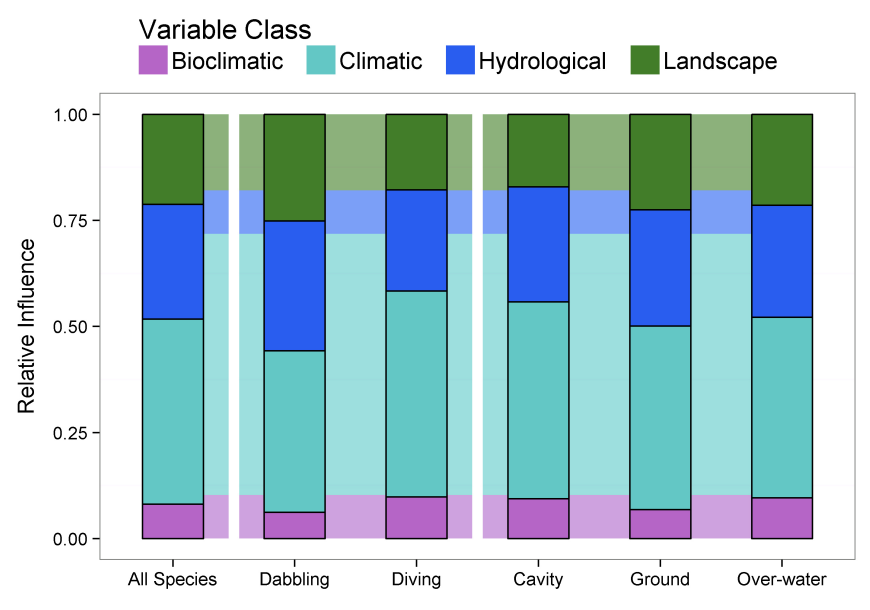

\section{DISCUSSION}

BRT models of waterfowl relative abundance performed well, according to a suite of standard evaluation metrics. Uncertainty maps show that predictions were most precise within the prairieparkland region, where WBPHS transect density is highest. On visual inspection, large-scale patterns in predicted species' abundances were congruent with spatial patterns in the raw data (Appendix 4). A map of total predicted waterfowl abundance identified many areas traditionally recognized for their importance to waterfowl, including the prairie-parkland region, the MacKenzie River Delta, the Peace-Athabasca Parklands, and the Saskatchewan River Delta. The differing magnitudes of residual spatial autocorrelation across scales are consistent with the main sources of unexplained spatial structure being processes acting at scales on the order of $10 \mathrm{~km}$, i.e., among adjacent segments. Possible examples would be population processes such as short-distance natal dispersal or unmeasured environmental factors varying at that scale. In either case, we do not expect parameter estimates or variable selection to be markedly biased.

Species' abundances followed two main patterns. In the first pattern, high abundances were predicted within a relatively small area, most often the prairie-parkland region. This pattern was most common for ground-nesting dabbling ducks. In the second pattern, comparatively low abundances were predicted evenly across much of Canada, with no well-defined core area. This pattern was most common among the cavity-nesting ducks but also applied to the Green-winged Teal and Ring-necked Duck. Model statistical performance varied consistently among these two patterns, with models for ground-nesting and dabbling species having higher predictive performance than those for other nesting and feeding guilds.

For many species, the most influential predictor variable appeared to correspond to spatial pattern rather than to a clear biological process. Species with most of their population contained within the prairie-parkland region tended to be associated with the amount of cropland, climate moisture index, and water body density. These three variables likely delineate the prairie-parkland region through its hydrological regime or soil composition (Environment Canada 2010), either directly or as reflected in the abundance of farmland in the region. Species with higher densities in the aspen parkland, such as the overwater-nesting diving ducks, showed more relationships with the amounts of open water and shoreline and with the abundance of cropland and croplandwoodland landcover classes. Wetlands in the aspen parkland tend to have less emergent vegetation than those in the prairies (Johnson et al. 2005), so the open-water variable may represent these parkland wetlands. Similarly, the aspen parkland has more wooded areas than the nearby prairie region, while also maintaining large amounts of farmland (Johnson et al. 2005, Wiken et al. 2011), so amounts of cropland and croplandwoodland would help to distinguish this region from the prairies to the south and closed forests to the north. For species not concentrated within the prairie-parkland region, climate means and bioclimatic indices were more important than landcover variables. Species with larger, more homogenous distributions, including the cavity nesters and Ring-necked Ducks, had relatively high associations with variability in seasonal temperatures. Species with geographic distributions not corresponding to the two main patterns, such as Scoters in the North and the American Black Duck in the East, showed unique combinations of variable importance: an overwhelming importance of climate for Scoters and an extremely strong influence of topography for the Black Duck. Our results for waterfowl contrast somewhat with those showing that climate and climate variability are most important in describing or determining songbird distributions (Cumming et al. 2014).

When the importance of environmental correlates is determined primarily by the continental-scale geographic distribution of species abundances, the variables selected as most important may not be causally related to the pattern of interest. For instance, the importance of cropland variables does not suggest that prairieparkland species prefer to nest within cropland. We are more likely 
to see noncausal relationships when using indirect environmental predictors. One could improve the biological correspondence of important variables by repeating the analyses at regional scales (e.g., N. Barker, unpublished report). For example, restricting the analysis of prairie-parkland species to segments within the prairie-parkland would likely reduce the apparent importance of amount of cropland and instead yield insight into drivers of finerscale patterns in abundance. In a regional analysis, it might be possible to use more direct environmental predictors rather than the proxies used here, because of increased data availability. These analyses might therefore yield more insight into biological relationships and habitat selection.

Waterfowl habitat selection has been summarized as "ducks like water" (Pimm 1994). Indeed, the most influential variable in 8 of our 17 species' models was a hydrological one, and at least 1 hydrological variable was among top 5 most important variables for 16 species. The single exception was the Scoters, for which the top water-related variable was ranked $23 \mathrm{rd}$. Our findings confirm that ducks do, in fact, like water. However, we have also shown that this glib summary is not the whole story. The type or distribution of water, or the way in which water is quantified, differs among species' models, depending on either life history traits or spatial distributions. For ground-nesting dabbling ducks, the top hydrological variables were usually water body density, climate moisture index, amount of shoreline, and amount of open water. For overwater-nesting ducks, both the amount of open water and the amount of shoreline were important. These variables likely help identify the prairie-parkland region and separate the prairies from the aspen parkland. For the broadly distributed cavity-nesting species and the Ring-necked Duck, the amount of open water was highly important, potentially because it best identified available wetlands outside of the prairieparkland region. The "amount of wetland" variable was in the top 20 variables for 9 species, but in the top 10 variables for only 2 species. Given the known dependence of many duck species on wetlands and marshes, particularly those with a hemimarsh condition of $50 \%$ plants and $50 \%$ open water (Murkin et al. 1982), it is surprising that this variable was relatively unimportant. We posit that this result stems from the difficulty of classifying wetlands from satellite imagery. A finer wetland classification system that separates wetlands into classes such as marsh, swamp, bogs, fens, river, and lake might shed more light on actual habitat selection and preference, although such a product has yet to be developed at the national extent. An even finer classification that incorporates detailed wetland attributes such as size, shoreline characteristics, bathymetry, phosphorus, food supply, and presence of fish would likely prove more effective, but no such data are available at national extents.

\section{Model limitations}

\section{Visibility correction}

The primary use of WBPHS data is to estimate annual continental waterfowl populations. Detection of waterfowl from aerial surveys is not perfect. The resulting counts are nearly always underestimates, although overestimates do occur, e.g., for Scaup (Austin et al. 2002). To account for incomplete detection in estimating continental population sizes, raw counts are adjusted by visibility correction factors (VCFs). VCFs are estimated from ground surveys on a subsample of survey segments (Smith 1995).
We did not incorporate these VCFs in our models for three reasons: (1) they were generated at the coarser crew area scale (Smith 1995), and this imprecision may lead to inaccurate visibility correction at the segment scale; (2) they were generated by different methods and frequencies for different regions (e.g., boreal vs. prairie-parkland; Smith 1995), casting doubt on the validity of comparing corrected abundances among regions; and (3) none are available for the eastern half of the survey area (Zimmerman et al. 2012), precluding the creation of Canada-wide models. We modeled the uncorrected observed counts. Under the assumption that detectability is constant across habitats, all observed counts are underestimated in the same proportion. Thus, our model predictions could be interpreted as relative abundances.

In fact, detectability does vary among habitats and species, as shown by the variation in VCFs among species and regions: $0.42-12.6$ in the boreal, $0.60-29.10$ in the prairie-parkland, and 0.92-10.30 in the tundra. Therefore, we expect results of our models to be biased in some degree, both in terms of predicted abundances and in the habitat associations identified. We have conducted some preliminary analyses comparing models with and without VCFs, and found that they yielded visually similar spatial patterns in predicted abundances and fairly similar identification of at least the top three influential habitat associations. Despite these apparent similarities, we encourage caution when comparing relative abundances between regions or among species, because VCFs are variable and our predicted maps are a combination of true abundances and unknown detection probabilities. We expect that our maps are most reliably used for single species within regions with relatively homogenous detectability. If desired, one could adjust our predictions post hoc using known VCFs. Our preliminary analyses suggested that the spatial variation in predictions echoed the variation in VCFs across crew areas. Therefore, one could simply multiply our predicted densities by VCFs where available, yielding a very rough approximation of VCF-corrected models. Our models and resulting predictions could certainly be improved were regionally specific VCFs, obtained at fine spatial scales using consistent methods, to become available.

\section{Late nesters}

For some species, surveys are conducted before pairs are settled on the breeding grounds (Austin et al. 2002). As a consequence, late-nesting species such as Scaup and Scoters may be observed outside their breeding ranges (Schummer et al. 2013). However, if migrating in groups, staging and migrating birds would be excluded from the total indicated pair count. We expect the numbers of out-of-range birds to be low relative to the numbers observed on the breeding grounds, even in late-nesting species. Therefore, we expect the influence of these observations on our models to be low. This is one advantage of having used segmentlevel counts, rather than presence, as the response variable.

\section{Variable interpretation}

There are limits to interpreting a BRT simply in terms of the most important variables. BRTs permit complex, nonlinear responses. Here, we specified a tree complexity of four, allowing several levels of interactions. With enough predictor variables, BRT models can likely match most observed spatial patterns. Therefore, even when the top variables are the same or similar across species, individual 
response curves and interactions can lead to substantial variation among fitted models and subsequent predictions of species' abundance. BRTs are therefore better suited for prediction than for biological understanding (Elith et al. 2008).

\section{Extrapolation}

Extrapolation, or out-of-sample prediction, occurs when we predict for times or locations not represented in the data (Wenger and Olden 2012). Coefficient-of-variation maps (Fig. 3 and Appendix 4) indicated more uncertainty outside the survey area than within, as expected. Within the survey area, we noticed localized areas of particularly high uncertainty near the coasts of very large water bodies, e.g., big lakes or oceans. This uncertainty may further be associated with extrapolation error. Models were built using data sampled near smaller water bodies, but were extrapolated to raster cells adjacent to extremely large water bodies.

We observed a few instances of clear overprediction outside the survey area, notably for the Scoters and the American Black Duck. The northern range of the Scoter group was best explained by climatic variables. These variables typically exhibit gradients, but only part of the range of these covariates was contained within the sampling space. As one consequence, predicted Scoter abundance was high in the far North of our study area, probably further north than they actually occur (Savard et al. 1998). Similarly, climatic and topographic variables explained spatial variation in American Black Duck numbers across the area sampled by the WBPHS. Conditions in Eastern Canada, where the Black Duck occurs, are also found in western coastal and southern interior British Columbia, where the species does not occur except as a few local introductions. Because these western areas are unsurveyed, our data set contained no information to constrain model creation. Therefore, the models predicted high abundances of the species because the habitat is theoretically suitable. One approach when faced with extrapolation errors would be clipping maps to regions of high confidence. We chose not to do this because these errors represent information, either pointing to potentially suitable habitat or to a need for methodological refinement.

Four factors may limit the extrapolation reliability of our models. First, while machine-learning techniques typically have high insample prediction reliability, they tend to have somewhat limited extrapolative ability because the models include complex nonlinear relationships (Wenger and Olden 2012). We attempted to restrict overfitting by using relatively simple trees, but this is not always sufficient. One solution is to use simpler models (Wenger and Olden 2012), such as generalized linear models, but these do not readily accommodate the number of predictor variables used here. An a priori reduced covariate set would be necessary, a step we specifically intended to avoid. As suggested by Cumming et al. (2014), it should be possible to use the most influential variables identified in this study as predictor variables in future generalized linear model analyses. Regional analyses may further facilitate the selection of a smaller set of predictors.

Second, model extrapolation is more accurate when predictions are restricted to the range of environmental conditions sampled and when the full relationship of species' abundance to predictors is captured (Thuiller et al. 2004, Randin et al. 2006, Elith and Leathwick 2009a). The figures within Appendix 1 suggest that unsurveyed portions within our study area present novel environmental conditions. This would account for the extrapolations of Scoters beyond the northern limit of published range maps. There is no easy solution to this problem. Ideally, new data or data from other sources would be collected or otherwise obtained for these regions (Audubon and Cornell Lab of Ornithology, eBird, http://ebird.org/content/ebird/).

Third, the set of environmental variables used in this analysis was limited by availability and extent, and included many indirect or proxy variables. This can degrade model prediction reliability (Mac Nally 2000, Randin et al. 2006). Prediction errors may occur if proxies are not causal or consistent across the study area (McIntire and Fajardo 2009).

Fourth, these models were based on environmental variables only, and did not account for historical or biological factors such as dispersal, evolution, or competition. If current patterns in waterfowl presence or abundance were influenced by such factors, then the resulting habitat model may predict theoretically suitable habitat rather than actual patterns in abundance or distribution. For example, the western limit of the American Black Ducks in central Canada may be because of biogeohistorical factors having nothing to do with current climate or topography. Further methodological research is necessary to explore the incorporation of such historical factors.

\section{Applications}

These models and the resulting maps suggest where, and for which species, existing range maps are in need of revision. For example, we predicted relatively high extralimital abundances of Ringnecked Duck. Having confirmed with raw survey data that our predictions accurately reflect observations of this species (Appendix 4), the range map of Ring-necked Duck could be updated. For other species, such as American Wigeon and Scoters, we predicted high extralimital abundances beyond the survey area. However, we would not recommend updating existing range maps for these species. Rather, in such cases, our predictions represent hypotheses derived from the existing data that should be tested against independent data.

Our models may also serve as guides for future modeling exercises or field studies. For instance, some future analyses may involve regional subsets of the data, to compare the variables identified as important in continental versus regional models. The prediction and associated uncertainty maps may guide where more research effort is needed, for instance in the southern Yukon where high abundances were predicted in association with high uncertainty. Future modeling focused on this area, particularly if accompanied by ground-truthing surveys, may identify important waterfowl areas for some species, or may simply show the current predictions to be an extrapolation error. In that case, definitive information would lead to reformulation of the models, possibly identifying more mechanistically informative variables. Extralimital predictions provide information for models of nonwaterfowl species as well. These unexpected occurrences can point to directions for future research in poorly surveyed areas of the breeding or wintering ranges.

Our goal was to produce predictive maps of waterfowl relative abundance, in large part to support the waterfowl conservation initiatives of Ducks Unlimited Canada. Although transect-level 
observations can yield an overall picture of waterfowl distributions and coarsely suggest some areas of high abundance, model prediction maps provide finer-scaled information over larger regions. The maps can also be used in future research to improve or compare modeling methods, to quantify aspects of waterfowl distribution ecology, and to evaluate and execute conservation planning strategies.

Responses to this article can be read online at: http://www.ace-eco.org/issues/responses.php/699

\section{Acknowledgments:}

The U.S. Fish and Wildlife Service and Canadian Wildlife Service collected and supplied waterfowl data, and we acknowledge their extensive support regarding the database. Dan McKenney and Pia Papadopol of Natural Resources Canada supplied several climatic data sets. We acknowledge the valuable contributions of M. Houle and P. Racine, who performed all PostGIS operations. Spatial analysis and assembly were supported by the Boreal Avian Modeling Project, the Canada Research Chairs program, and the Canada Foundation for Innovation. N. Barker was funded by an Industrial Innovation Scholarship from Natural Sciences and Engineering Research Council of Canada and the Fonds québécois de la recherche sur la nature et les technologies, a Fellowship Grant from the Ducks Unlimited Canada-Institute for Wetland and Waterfowl Research, and a Natural Sciences and Engineering Research Council of Canada Discovery Grant to S. Cumming. We thank S. Slattery, J. Nowak, C. Roy, E. Racine, S. Renard, D. Stralberg, S. Bauduin, E. McIntire, T. Nudds, K. Swiston, an anonymous reviewer, and a subject editor for discussion andlor comments. This study benefited from funding by Ducks Unlimited Canada and Ducks Unlimited Inc.

\section{LITERATURE CITED}

Anderson, D. R. 1975. Population ecology of the mallard $V$. Temporal and geographic estimates of survival, recovery, and harvest rates. U.S. Fish and Wildlife Service resource publication 125. U. S. Fish and Wildlife Service, Washington, DC, USA.

Anderson, R. P., A. T. Peterson, and M. Gómez-Laverde. 2002. Using niche-based GIS modeling to test geographic predictions of competitive exclusion and competitive release in South American pocket mice. Oikos 98:3-16. http://dx.doi.org/10.1034/ j.1600-0706.2002.t01-1-980116.x

Araújo, M. B., M. Cabeza, W. Thuiller, L. Hannah, and P. H. Williams. 2004. Would climate change drive species out of reserves? An assessment of existing reserve-selection methods. Global Change Biology 10:1618-1626. http://dx.doi.org/10.1111/ j.1365-2486.2004.00828.x

Austin, J. E., D. A. Granfors, M. A. Johnson, and S. C. Kohn. 2002. Scaup migration patterns in North Dakota relative to temperatures and water conditions. Journal of Wildlife Management 66:874-882. http://dx.doi.org/10.2307/3803152

Austin, M. P. 2002. Spatial prediction of species distribution: an interface between ecological theory and statistical modeling.
Ecological Modelling 157:101-118. http://dx.doi.org/10.1016/ S0304-3800(02)00205-3

Badiou, P., R. Baldwin, M. Carlson, M. Darveau, P. Drapeau, K. Gaston, J. Jacobs, J. Kerr, S. Levin, M. Manseau, G. Orians, S. Pimm, H. Possingham, P. Raven, F. Reid, D. Roberts, T. L. Root, N. T. Roulet, J. Schaefer, D. Schindler, J. Stritthold, N. Turner, and J. Wells. 2013. Conserving the world's last great forest is possible: here's how. Briefing note. International Boreal Conservation Science Panel. [online] URL: http://borealscience. org/wp-content/uploads/2013/07/conserving-last-great-forests1.pdf

Barry, S., and J. Elith. 2006. Error and uncertainty in habitat models. Journal of Applied Ecology 43:413-423. http://dx.doi. org/10.1111/j.1365-2664.2006.01136.x

Bellrose, F. C. 1980. Ducks geese \& swans of North America. Stackpole, Harrisburg, Pennsylvania, USA.

Berteaux, D. 2013. Québec's large-scale Plan Nord. Conservation Biology 27:242-243. http://dx.doi.org/10.1111/cobi.12018

Börger, L., and T. D. Nudds. 2014. Fire, humans and climate: modeling distribution dynamics of boreal forest waterbirds. Ecological Applications 24:121-141. http://dx.doi.org/10.1890/12-1683.1

Brandt, J. P. 2009. The extent of the North American boreal zone Environmental Reviews 17:101-161. http://dx.doi.org/10.1139/ A09-004

Canada Centre for Remote Sensing. 2008. Land cover map of Canada 2005. Natural Resources Canada, Ottawa, Ontario, Canada. [online] URL: ftp://ftp.ccrs.nrcan.gc.ca/ad/NLCCLandCover/ LandcoverCanada2005_250m/

Cumming, S. G., D. Stralberg, K. L. Lefevre, P. Sólymos, E. M. Bayne, S. Fang, T. Fontaine, D. Mazerolle, F. K. A. Schmiegelow, and S. J. Song. 2014. Climate and vegetation hierarchically structure patterns of songbird distribution in the Canadian boreal region. Ecography 37:137-151. http://dx.doi.org/10.1111/ j.1600-0587.2013.00299.x

Drever, M. C., R. G. Clark, C. Derksen, S. M. Slattery, P. Toose, and T. D. Nudds. 2012. Population vulnerability to climate change linked to timing of breeding in boreal ducks. Global Change Biology 18:480-492. http://dx.doi.org/10.1111/j.1365-2486.2011.02541.

\section{$\mathrm{x}$}

Dzubin, A. 1969. Assessing breeding populations of ducks by ground counts. Saskatoon Wetlands Seminar. Canadian Wildlife Service Report Series Number 6. Northern Prairie Wildlife Research Center Online. Northern Prairie Wildlife Research Center, Jamestown, North Dakota, USA. [online] URL: http:// www.npwrc.usgs.gov/resource/birds/duckcoun/index.htm

Elith, J., C. H. Graham, R. P. Anderson, M. Dudík, S. Ferrier, A. Guisan, R. J. Hijmans, F. Huettmann, J. R. Leathwick, A. Lehmann, J. Li, L. G. Lohmann, B. A. Loiselle, G. Manion, C. Moritz, M. Nakamura, Y. Nakazawa, J. McC. M. Overton, A. T. Peterson, S. J. Phillips, K. Richardson, R. Scachetti-Pereira, R. E. Schapire, J. Soberón, S. Williams, M. S. Wisz, and N. E. Zimmermann. 2006. Novel methods improve prediction of species' distributions from occurrence data. Ecography 29:129-151. http://dx.doi.org/10.1111/j.2006.0906-7590.04596.x

Elith, J., and J. Leathwick. 2009b. The contribution of species distribution modeling to conservation prioritization. Pages 70-93 
in Spatial conservation prioritization: quantitative methods and computational tools. Oxford University Press, Oxford, UK.

Elith, J., and J. R. Leathwick. 2009a. Species distribution models: ecological explanation and prediction across space and time. Annual Review of Ecology, Evolution, and Systematics 40:677-697. http://dx.doi.org/10.1146/annurev.ecolsys.110308.120159

Elith, J., J. R. Leathwick, and T. Hastie. 2008. A working guide to boosted regression trees. Journal of Animal Ecology 77:802-813. http://dx.doi.org/10.1111/j.1365-2656.2008.01390.x

Environment Canada. 2010. Ecozone and ecoregion descriptions. Environment Canada, Ottawa, Ontario, Canada. [online] URL: http://ecozones.ca/english/zone/index.html

Ferrier, S. 2002. Mapping spatial pattern in biodiversity for regional conservation planning: where to from here? Systematic Biology 51:331-363. http://dx.doi.org/10.1080/10635150252899806

Friedman, J. H. 2001. Greedy function approximation: a gradient boosting machine. Annals of Statistics 29:1189-1232. http://dx. doi.org/10.1214/aos/1013203451

Friedman, J. H. 2002. Stochastic gradient boosting. Computational Statistics \& Data Analysis 38:367-378. http://dx. doi.org/10.1016/S0167-9473(01)00065-2

Friedman, J., T. Hastie, and R. Tibshirani. 2000. Additive logistic regression: a statistical view of boosting (with discussion and a rejoinder by the authors). Annals of Statistics 28:337-407. http:// dx.doi.org/10.1214/aos/1016218223

Friedman, J. H., and J. J. Meulman. 2003. Multiple additive regression trees with application in epidemiology. Statistics in Medicine 22:1365-1381. http://dx.doi.org/10.1002/sim.1501

Gaston, K. J. 2003. The structure and dynamics of geographic ranges. Oxford University Press, Oxford, UK.

Gimenez, O., S. J. Bonner, R. King, R. A. Parker, S. P. Brooks, L. E. Jamieson, V. Grosbois, B. J. T. Morgan, and L. Thomas. 2009. WinBUGS for population ecologists: Bayesian modeling using Markov chain Monte Carlo methods. Pages 883-915 in D. L. Thomson, E. G. Cooch, and M. J. Conroy, editors. Modeling demographic processes in marked populations. Volume 3. Springer US, New York, New York, USA. http://dx.doi.org/10.1007/978-0-387-78151-8_41

Guisan, A., and N. E. Zimmermann. 2000. Predictive habitat distribution models in ecology. Ecological modeling 135:147-186. http://dx.doi.org/10.1016/S0304-3800(00)00354-9

Hijmans, R. J., S. Phillips, J. Leathwick, and J. Elith. 2012. dismo: species distribution modeling. $\mathrm{R}$ package version $0.7-17$. R Foundation for Statistical Computing, Vienna, Austria. [online] URL: http://CRAN.R-project.org/package=dismo

Hobson, K. A., M. B. Wunder, S. L. Van Wilgenburg, R. G. Clark, and L. I. Wassenaar. 2009. A method for investigating population declines of migratory birds using stable isotopes: origins of harvested lesser scaup in North America. PLoS ONE 4:e7915. http://dx.doi.org/10.1371/journal.pone.0007915

Horn, D. J., M. L. Phillips, R. R. Koford, W. R. Clark, M. A. Sovada, and R. J. Greenwood. 2005. Landscape composition, patch size, and distance to edges: interactions affecting duck reproductive success. Ecological Applications 15:1367-1376. http://dx.doi.org/10.1890/03-5254

Integrated Remote Sensing Studio. 2010. Canadian boreal ruggedness. Data Basin. Conservation Biology Institute, Corvallis, Oregon, USA. [online] URL: http://databasin.org/ datasets/14d70746535e4be99aaf66595cc0b677

Jamieson, L. E., and S. P. Brooks. 2004. Density dependence in North American ducks. Animal Biodiversity and Conservation 27:113-128.

Jetz, W., D. S. Wilcove, and A. P. Dobson. 2007. Projected impacts of climate and land-use change on the global diversity of birds. PLoS Biology 5:e157. http://dx.doi.org/10.1371/journal.pbio.0050157

Johnsgard, P. 2010. Waterfowl of North America. Revised edition. University of Nebraska-Lincoln Libraries, Lincoln, Nebraska, USA.

Johnson, D. H., and J. W. Grier. 1988. Determinants of breeding distributions of ducks. Wildlife Monographs 100:3-37.

Johnson, D. H., and T. L. Shaffer. 1987. Are mallards declining in North America? Wildlife Society Bulletin 15:340-345.

Johnson, W. C., B. V. Millett, T. Gilmanov, R. A. Voldseth, G. R. Guntenspergen, and D. E. Naugle. 2005. Vulnerability of northern prairie wetlands to climate change. BioScience 55:863-872. http://dx.doi.org/10.1641/0006-3568(2005)055[0863: VONPWT]2.0.CO;2

Kaminski, R. M., and E. A. Gluesing. 1987. Density- and habitatrelated recruitment in mallards. Journal of Wildlife Management 51:141-148. http://dx.doi.org/10.2307/3801645

Lawrence, J. D., R. B. Gramacy, L. Thomas, and S. T. Buckland. 2013. The importance of prior choice in model selection: a density dependence example. Methods in Ecology and Evolution 4:25-33. http://dx.doi.org/10.1111/j.2041-210X.2012.00255.x

Leathwick, J. R. 1998. Are New Zealand's Nothofagus species in equilibrium with their environment? Journal of Vegetation Science 9:719-732. http://dx.doi.org/10.2307/3237290

Lemelin, L.-V., M. Darveau, L. Imbeau, and D. Bordage. 2010. Wetland use and selection by breeding waterbirds in the boreal forest of Quebec, Canada. Wetlands 30:321-332. http://dx.doi. org/10.1007/s13157-010-0024-Z

Loiselle, B. A., C. A. Howell, C. H. Graham, J. M. Goerck, T. Brooks, K. G. Smith, and P. H. Williams. 2003. Avoiding pitfalls of using species distribution models in conservation planning. Conservation Biology 17:1591-1600. http://dx.doi.org/10.1111/ j.1523-1739.2003.00233.X

Lu, H. H.-S., B. Schölkopf, and H. Zhao, editors. 2011. Handbook of statistical bioinformatics. Springer, New York, New York, USA. http://dx.doi.org/10.1007/978-3-642-16345-6

Lynch, H. J., M. Rhainds, J. M. Calabrese, S. Cantrell, C. Cosner, and W. F. Fagan. 2014. How climate extremes - not meansdefine a species' geographic range boundary via a demographic tipping point. Ecological Monographs 84:131-149. http://dx.doi. org/10.1890/12-2235.1 
Mac Nally, R. 2000. Regression and model-building in conservation biology, biogeography and ecology: the distinction between - and reconciliation of - 'predictive' and 'explanatory' models. Biodiversity \& Conservation 9:655-671. http://dx.doi. org/10.1023/A:1008985925162

McIntire, E. J. B., and A. Fajardo. 2009. Beyond description: the active and effective way to infer processes from spatial patterns. Ecology 90:46-56. http://dx.doi.org/10.1890/07-2096.1

McKenney, D. W., M. F. Hutchinson, P. Papadopol, K. Lawrence, J. Pedlar, K. Campbell, E. Milewska, R. F. Hopkinson, D. Price, and T. Owen. 2011. Customized spatial climate models for North America. Bulletin of the American Meteorological Society 92:1611-1622. http://dx.doi.org/10.1175/2011BAMS3132.1

Milsom, T. P., S. D. Langton, W. K. Parkin, S. Peel, J. D. Bishop, J. D. Hart, and N. P. Moore. 2000. Habitat models of bird species' distribution: an aid to the management of coastal grazing marshes. Journal of Applied Ecology 37:706-727. http://dx.doi. org/10.1046/j.1365-2664.2000.00529.X

Moilanen, A., A. M. A. Franco, R. I. Early, R. Fox, B. Wintle, and C. D. Thomas. 2005. Prioritizing multiple-use landscapes for conservation: methods for large multi-species planning problems. Proceedings of the Royal Society B: Biological Sciences 272:1885-1891. http://dx.doi.org/10.1098/rspb.2005.3164

Morrison, M. L., B. Marcot, and W. Mannan. 2006. Wildlifehabitat relationships: concepts and applications. Island Press, Washington, D.C., USA.

Murkin, H. R., R. M. Kaminski, and R. D. Titman. 1982. Responses by dabbling ducks and aquatic invertebrates to an experimentally manipulated cattail marsh. Canadian Journal of Zoology 60:2324-2332. http://dx.doi.org/10.1139/z82-299

Natural Resources Canada. 2007. National hydro network, Canada. Natural Resources Canada, Earth Sciences Sector, Centre for Topographic Information, Sherbrooke, Quebec, Canada.

Nichols, J. D., F. A. Johnson, and B. K. Williams. 1995. Managing North American waterfowl in the face of uncertainty. Annual Review of Ecology and Systematics 26:177-199. http://dx.doi. org/10.1146/annurev.es.26.110195.001141

Obe, R., and L. Hsu. 2011. PostGIS in action. Manning, Greenwich, Connecticut, USA.

Oppel, S., A. Meirinho, I. Ramírez, B. Gardner, A. F. O’Connell, P. I. Miller, and M. Louzao. 2012. Comparison of five modeling techniques to predict the spatial distribution and abundance of seabirds. Biological Conservation 156:94-104. http://dx.doi. org/10.1016/j.biocon.2011.11.013

Ortega-Huerta, M. A., and A. T. Peterson. 2004. modeling spatial patterns of biodiversity for conservation prioritization in Northeastern Mexico. Diversity and Distributions 10:39-54. http://dx. doi.org/10.1111/j.1472-4642.2004.00051.x

Paszkowski, C. A., and W. M. Tonn. 2006. Foraging guilds of aquatic birds on productive boreal lakes: environmental relations and concordance patterns. Hydrobiologia 567:19-30. http://dx. doi.org/10.1007/s10750-006-0053-z
Pimm, S. L. 1994. The importance of watching birds from airplanes. Trends in Ecology \& Evolution 9:41-43. http://dx.doi. org/10.1016/0169-5347(94)90264-X

Podruzny, K. M., J. H. Devries, L. M. Armstrong, and J. J. Rotella. 2002. Long-term response of northern pintails to changes in wetlands and agriculture in the Canadian Prairie Pothole Region. Journal of Wildlife Management 66:993-1010. http://dx.doi. org/10.2307/3802932

Pospahala, R. S., D. R. Anderson, and C. J. Henny. 1974. Population ecology of the Mallard II: breeding habitat conditions, size of the breeding populations, and production indices. U.S. Fish and Wildlife Service Resource Publication. U.S. Fish and Wildlife Service, Washington, D.C., USA.

R Core Team. 2012. R: a language and environment for statistical computing. R Foundation for Statistical Computing, Vienna, Austria. [online] URL: http://www.R-project.org/

Randin, C. F., T. Dirnböck, S. Dullinger, N. E. Zimmermann, M. Zappa, and A. Guisan. 2006. Are niche-based species distribution models transferable in space? Journal of Biogeography 33:1689-1703. http://dx.doi.org/10.1111/j.1365-2699.2006.01466. $\mathrm{x}$

Raveling, D. G., and M. E. Heitmeyer. 1989. Relationships of population size and recruitment of pintails to habitat conditions and harvest. Journal of Wildlife Management 53:1088-1103. http://dx.doi.org/10.2307/3809615

Ridgeway, G. 2013. gbm: generalized boosted regression models. $\mathrm{R}$ package version 2.1. R Foundation for Statistical Computing, Vienna, Austria. [online] URL: http://CRAN.R-project.org/ package $=\mathrm{gbm}$

Ross, B. E., M. B. Hooten, and D. N. Koons. 2012. An accessible method for implementing hierarchical models with spatiotemporal abundance data. PLoS ONE 7:e49395. http://dx.doi. org/10.1371/journal.pone.0049395

Savard, J.-P. L., D. Bordage, and A. Reed. 1998. Surf Scoter (Melanitta perspicillata). The birds of North America online. Cornell Lab of Ornithology, Ithaca, New York, USA. [online] URL: http://dx.doi.org/10.2173/bna.363

Schindler, D. W., and P. G. Lee. 2010. Comprehensive conservation planning to protect biodiversity and ecosystem services in Canadian boreal regions under a warming climate and increasing exploitation. Biological Conservation 143:1571-1586. http://dx.doi.org/10.1016/j.biocon.2010.04.003

Schummer, M. L., A. D. Afton, S. S. Badzinski, S. A. Petrie, G. Olsen, K. Jacobs, M. Mitchell, and S. Jenkins. 2013. Using satellite telemetry to evaluate the effectiveness of the waterfowl breeding population and habitat survey for counting lesser and greater scaup in North America. Oral presentation. Ecology and Conservation of North American Waterfowl, Memphis, Tennessee, USA. [online] URL: http://www.northamericanducksymposium.org/ docs/New\%20Approaches\%20and\%20Methods.pdf

Silverman, E. D. 2011. Waterfowl breeding population and habitat survey-traditional survey. Division of Migratory Bird Management, U.S. Fish and Wildlife Service, Laurel, Maryland, 
USA. [online] URL: https://migbirdapps.fws.gov/mbdc/databases/ mas/aboutmas.htm

Slattery, S. M., J. L. Morissette, G. G. Mack, and E. W. Butterworth. 2011. Waterfowl conservation planning: science needs and approaches. Pages 23-40 in J. V. Wells, editor. Boreal birds of North America: a hemispheric view of their conservation links and significance. Studies in Avian Biology No. 41. Cooper Ornithological Society, University of California Press, Oakland, California, USA.

Smith, G. W. 1995. A critical review of the aerial and ground surveys of breeding waterfowl in North America. Biological science report. U.S. National Biological Service, Washington, D.C., USA.

Sólymos, P., S. M. Matsuoka, E. M. Bayne, S. R. Lele, P. Fontaine, S. G. Cumming, D. Stralberg, F. K. A. Schmiegelow, and S. J. Song. 2013. Calibrating indices of avian density from nonstandardized survey data: making the most of a messy situation. Methods in Ecology and Evolution 4:1047-1058. http://dx.doi. org/10.1111/2041-210X.12106

Stralberg, D., S. M. Matsuoka, A. Hamann, E. M. Bayne, P. Sólymos, F. Schmiegelow, X. Wang, S. G. Cumming, and S. J. Song. 2014. Projecting boreal bird responses to climate change: the signal exceeds the noise. Ecological Applications, in press. http://dx.doi.org/10.1890/13-2289.1

Suhonen, S., P. Nummi, and H. Poysa. 2011. Long term stability of boreal lake habitats and use by breeding ducks. Boreal Environment Research 16:71-80.
Thuiller, W. 2004. Patterns and uncertainties of species' range shifts under climate change. Global Change Biology 10:2020-2027. http://dx.doi.org/10.1111/j.1365-2486.2004.00859.x

Thuiller, W., L. Brotons, M. B. Araújo, and S. Lavorel. 2004. Effects of restricting environmental range of data to project current and future species distributions. Ecography 27:165-172. http://dx.doi.org/10.1111/j.0906-7590.2004.03673.x

Titman, R. D. 1999. Red-breasted Merganser (Mergus serrator). The birds of North America online. Cornell Lab of Ornithology, Ithaca, New York, USA. http://dx.doi.org/10.2173/bna.443

U.S. Fish and Wildlife Service. 2012. Waterfowl population status, 2012. Report. U.S. Department of the Interior, Washington, D. C., USA.

Wenger, S. J., and J. D. Olden. 2012. Assessing transferability of ecological models: an underappreciated aspect of statistical validation. Methods in Ecology and Evolution 3:260-267. http:// dx.doi.org/10.1111/j.2041-210X.2011.00170.x

Wiken, E., F. Jiménez Nava, and G. Griffith. 2011. North American terrestrial ecoregions - level III. Commission for Environmental Cooperation, Montreal, Quebec, Canada.

Zimmerman, G. S., J. R. Sauer, W. A. Link, and M. Otto. 2012. Composite analysis of black duck breeding population surveys in eastern North America. Journal of Wildlife Management 76:1165-1176. http://dx.doi.org/10.1002/jwmg.351
Editor-in-Chief: Keith A.Hobson Subject Editor: Scott Wilson
Sponsored by the Society of Canadian Ornithologists and Bird Studies Canada Parrainée par la Société des ornithologistes $d u$ Canada et Études d'oiseaux Canada 
Appendix 1. Environmental variables used in Boosted Regression Trees of waterfowl abundance. The table describes each variable while the figures depict the range of each variable within the WBPHS segments (model input) and within the entire study area (study area).

\begin{tabular}{|c|c|c|c|c|}
\hline Variable & $\begin{array}{l}\text { Time } \\
\text { Period }\end{array}$ & Resolution & Source & Calculation \\
\hline \multicolumn{5}{|l|}{ Climatic } \\
\hline $\begin{array}{l}\text { mumaxt } x \text { : } 30 \text {-year mean maximum } \\
\text { temperature in season } x^{a} \text { ( }=4 \text { seasons) }\end{array}$ & $\begin{array}{l}1981- \\
2010\end{array}$ & $10 \mathrm{~km}$ & NRCANb & $\begin{array}{l}\text { Mean calculated for each cell } \\
\text { across } 30 \text { years of monthly grids. } \\
\text { Weighted mean calculated for } \\
\text { each unitc. Seasonal mean } \\
\text { calculated. }\end{array}$ \\
\hline $\begin{array}{l}\text { mumint } x \text { : } 30 \text {-year mean minimum } \\
\text { temperature in season } x^{a}(n=4 \text { seasons) }\end{array}$ & $"$ & $"$ & $"$ & " \\
\hline $\begin{array}{l}\text { mupcpx: } 30 \text {-year mean precipitation in } \\
\text { season } x^{a}(n=4 \text { seasons })\end{array}$ & $"$ & $"$ & $"$ & $"$ \\
\hline $\begin{array}{l}\text { sdmaxtx: } 30 \text {-year standard deviation of } \\
\text { maximum temperature in month } x(n=12 \\
\text { months) }\end{array}$ & $"$ & $"$ & $"$ & $\begin{array}{l}\text { Standard deviation calculated for } \\
\text { each cell across } 30 \text { years of } \\
\text { monthly grids. Weighted mean } \\
\text { calculated for each unit. }\end{array}$ \\
\hline $\begin{array}{l}\text { sdmintx:30-year standard deviation of } \\
\text { minimum temperature in month } x(n=12 \\
\text { months) }\end{array}$ & $"$ & $"$ & $"$ & 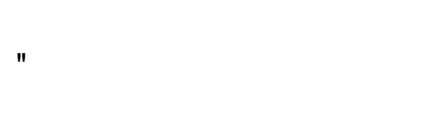 \\
\hline $\begin{array}{l}\text { sdpcpx:30-year standard deviation of } \\
\text { precipitation in month } x(n=12 \text { months })\end{array}$ & $"$ & $"$ & $"$ & $"$ \\
\hline $\begin{array}{l}\text { Bioclimatic } \\
\text { tmpseas: } 30 \text {-year mean temperature } \\
\text { seasonality; monthly mean variance } \\
\text { around the annual mean }(n=1) \\
\text { pcnseas: } 30 \text {-vear mean precipitation }\end{array}$ & $"$ & $"$ & $"$ & $\begin{array}{l}\text { Mean calculated for each cell } \\
\text { across } 30 \text { annual grids. Weighted } \\
\text { mean calculated for each unit. }\end{array}$ \\
\hline $\begin{array}{l}\text { seasonality; monthly mean variance } \\
\text { around the annual mean }(n=1) \\
\text { temprange: } 30 \text {-year mean temperature }\end{array}$ & $"$ & $"$ & $"$ & $"$ \\
\hline $\begin{array}{l}\text { annual range; difference between the } \\
\text { maximum of the warmest month and the } \\
\text { minimum of the coldest month }(n=1)\end{array}$ & $"$ & $"$ & $"$ & $"$ \\
\hline $\begin{array}{l}\text { wetmonth:30-year mean of precipitation } \\
\text { in wettest month }(n=1)\end{array}$ & $"$ & $"$ & $"$ & $"$ \\
\hline $\begin{array}{l}\text { drymonth: } 30 \text {-year mean of } \\
\text { precipitation in driest month }(n=1)\end{array}$ & $"$ & $"$ & $"$ & $"$ \\
\hline $\begin{array}{l}\text { mugrow: } 30 \text {-year mean of growing } \\
\text { season length; number of days above } \\
5^{\circ} \mathrm{C}(\mathrm{n}=1)\end{array}$ & $"$ & $"$ & $"$ & $"$ \\
\hline $\begin{array}{l}\text { sdgrow: } 30 \text {-year standard deviation of } \\
\text { growing season length }(n=1)\end{array}$ & $"$ & $"$ & $"$ & $"$ \\
\hline $\begin{array}{l}\text { gpp: 7-year average gross primary } \\
\text { productivity, in } \mathrm{gC} / \mathrm{m}^{2} / \mathrm{yr} \text { ( }(\mathrm{n}=1)\end{array}$ & $\begin{array}{l}2000- \\
2006\end{array}$ & $1 \mathrm{~km}$ & $\begin{array}{l}\text { Numerical } \\
\text { Terradynamic } \\
\text { Simulation } \\
\text { Group }\end{array}$ & $\begin{array}{l}\text { Weighted mean calculated for } \\
\text { each unit. }\end{array}$ \\
\hline
\end{tabular}




\begin{tabular}{|c|c|c|c|c|}
\hline Variable & $\begin{array}{l}\text { Time } \\
\text { Period }\end{array}$ & Resolution & Source & Calculation \\
\hline \multicolumn{5}{|l|}{ Landscape } \\
\hline $\begin{array}{l}\text { Icc.C.i: Proportion of area covered by } \\
\text { land cover class } i, \text { described in Table A2 } \\
\text { ( } n=12 \text { cover classes). }\end{array}$ & $\begin{array}{l}\text { Static } \\
(2005)\end{array}$ & $250 \mathrm{~m}$ & $\begin{array}{l}\text { Centre for } \\
\text { Remote } \\
\text { Sensingg }\end{array}$ & $\begin{array}{l}\qquad \mathrm{Ci} / \mathrm{Ct} \\
\mathrm{Ci}=\text { Count of cells of land } \mathrm{c} \text { class } \mathrm{i} \\
\text { within unit }\end{array}$ \\
\hline sdi: Shannon Diversity Index for land & & & & $\mathrm{Ct}=$ Total cell count in unit \\
\hline cover classes $(n=1)$ & " & " & " & $\begin{array}{l}\left.\quad \sum_{i=1}(P i * \ln (P i))\right) \\
\mathrm{m}=\text { number of land cover types } \\
\mathrm{Pi}=\text { proportion of area covered by } \\
\text { land cover type }\end{array}$ \\
\hline topo: Index of topographic ruggedness; & Static & $1 \mathrm{~km}$ & Integrated & Weighted mean calculated for \\
\hline calculated as coefficient of variation & (2000 and & & Remote & each unit. \\
\hline from a DEM $(n=1)$ & $\begin{array}{l}\text { 1993- } \\
1996)\end{array}$ & & $\begin{array}{l}\text { Sensing } \\
\text { Studioi }\end{array}$ & \\
\hline \multicolumn{5}{|l|}{ Hydrological } \\
\hline $\begin{array}{l}\text { cmi: } 30 \text {-year average climate moisture } \\
\text { index; } \mathrm{cm} \text { precipitation }-\mathrm{cm} \text { potential } \\
\text { evaporation per yeard }(\mathrm{n}=1)\end{array}$ & $\begin{array}{l}1961- \\
1990\end{array}$ & $10 \mathrm{~km}$ & NRCAN & $\begin{array}{l}\text { Weighted mean calculated for } \\
\text { each unit. }\end{array}$ \\
\hline $\begin{array}{l}\text { hwlwetland/hwlwater: Proportion of } \\
\text { area covered by open water or wetlandsi } \\
\text { ( } n=2 \text { classes) }\end{array}$ & $\begin{array}{l}\text { Static } \\
\text { (2000 and } \\
2009)\end{array}$ & $25 \mathrm{~m}$ & $\begin{array}{l}\text { Ducks } \\
\text { Unlimited } \\
\text { Canada }\end{array}$ & $\begin{array}{l}\text { Count of water or wetland cells } \\
\text { within each unit, expressed as a } \\
\text { proportion of total number of cells } \\
\text { within unit. }\end{array}$ \\
\hline $\begin{array}{l}\text { streamlength: Total length of streams } \\
\text { in } \mathrm{m} \text { stream } / \mathrm{km}^{2} \text { area }(n=1)\end{array}$ & $\begin{array}{c}\text { Static } \\
\text { (created } \\
\text { from data } \\
\text { from } \\
1994- \\
2010)\end{array}$ & $\begin{array}{l}1: 10,000- \\
1: 50,000\end{array}$ & $\begin{array}{l}\text { National } \\
\text { Hydrology } \\
\text { Networkj }\end{array}$ & $\begin{array}{l}\text { Length of all streams, divided by } \\
\text { unit area (to standardize). }\end{array}$ \\
\hline $\begin{array}{l}\text { wbdens: Density of water bodies in unit } \\
\text { neighbourhood }(n=1)\end{array}$ & $"$ & $"$ & $"$ & $\begin{array}{l}\text { Number of water bodies } \\
\text { intersected by unit, divided by unit } \\
\text { area (to standardize). }\end{array}$ \\
\hline $\begin{array}{l}\text { muareawbods: Mean size of water } \\
\text { bodies in unit neighbourhood }(n=1)\end{array}$ & $"$ & $"$ & $"$ & $\begin{array}{l}\text { Mean area of water bodies } \\
\text { intersected by unit, divided by unit } \\
\text { area (to standardize). }\end{array}$ \\
\hline $\begin{array}{l}\text { shorelength: Length of shoreline in } \mathrm{km} \\
\text { shoreline } / \mathrm{km}^{2} \text { area }(n=1)\end{array}$ & $"$ & $"$ & $"$ & $\begin{array}{l}\text { Total shoreline (perimeter of water } \\
\text { bodies) contained within unit, } \\
\text { divided by unit area (to } \\
\text { standardize). }\end{array}$ \\
\hline $\begin{array}{l}\text { shorecx: Shoreline complexity (area- } \\
\text { weighted shape index for water bodies } \\
\text { in unit neighbourhood) }(n=1)\end{array}$ & $"$ & $"$ & $"$ & $\begin{array}{l}\text { Ratio of water body perimeter to } \\
\text { area measured against a circle } \\
\text { standard. Mean across water } \\
\text { bodies weighted by area of water } \\
\text { body within unit. }\end{array}$ \\
\hline
\end{tabular}


a Seasons as follows: Winter: Dec, Jan, Feb; Spring: Mar, Apr, May; Summer: Jun, Jul, Aug; Autumn: Sept, Oct, Nov.

b McKenney, D. W., M. F. Hutchinson, P. Papadopol, K. Lawrence, J. Pedlar, K. Campbell, E. Milewska, R. F. Hopkinson, D.

Price, and T. Owen. 2011. Customized spatial climate models for North America. Bulletin of the American Meteorological Society 92:1611-1622.

${ }^{c}$ unit $=$ segment buffer or grid cell (see Methods: Environmental data).

d Calculated from modified Penman-Monteith potential evapotranspiration. Hogg, E. H. 1994. Climate and the southern limit of the western Canadian boreal forest. Canadian Journal of Forest Research 24:1835-1845.

e from the MOD17A3 product. Zhao, M., F. A. Heinsch, R. R. Nemani, and S. W. Running. 2005. Improvements of the MODIS terrestrial gross and net primary production global data set. Remote Sensing of Environment 95:164-176.

(http://www.ntsg.umt.edu/project/mod17)

f NTSG at the University of Montana. (http://www.ntsg.umt.edu/)

9 Latifovic 2008. Landcover Map of Canada 2005. (http://www.nrcan.gc.ca/earth-sciences/geography-boundary/remote-

sensing/optical/2208)

h Integrated Remote Sensing Studio (http://databasin.org/datasets/14d70746535e4be99aaf66595cc0b677)

i Jones, N. 2010. Hybrid Wetland Layer (Version 2.1) User Guide. Ducks Unlimited Canada.

j National Hydrology Network. 2007. Government of Canada. Available on Geobase.

(http://www.geobase.ca/geobase/en/data/nhn/description.html) 


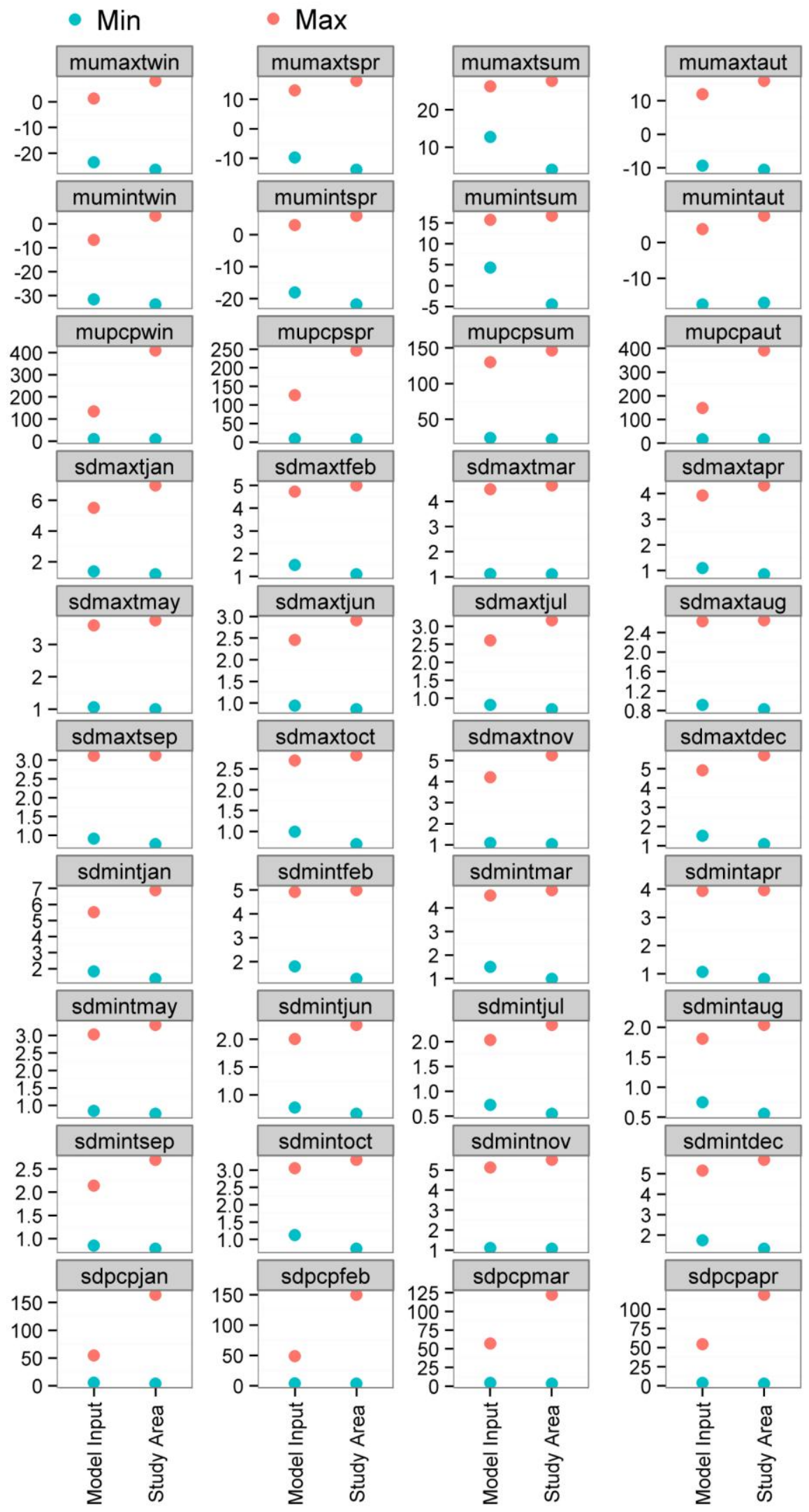




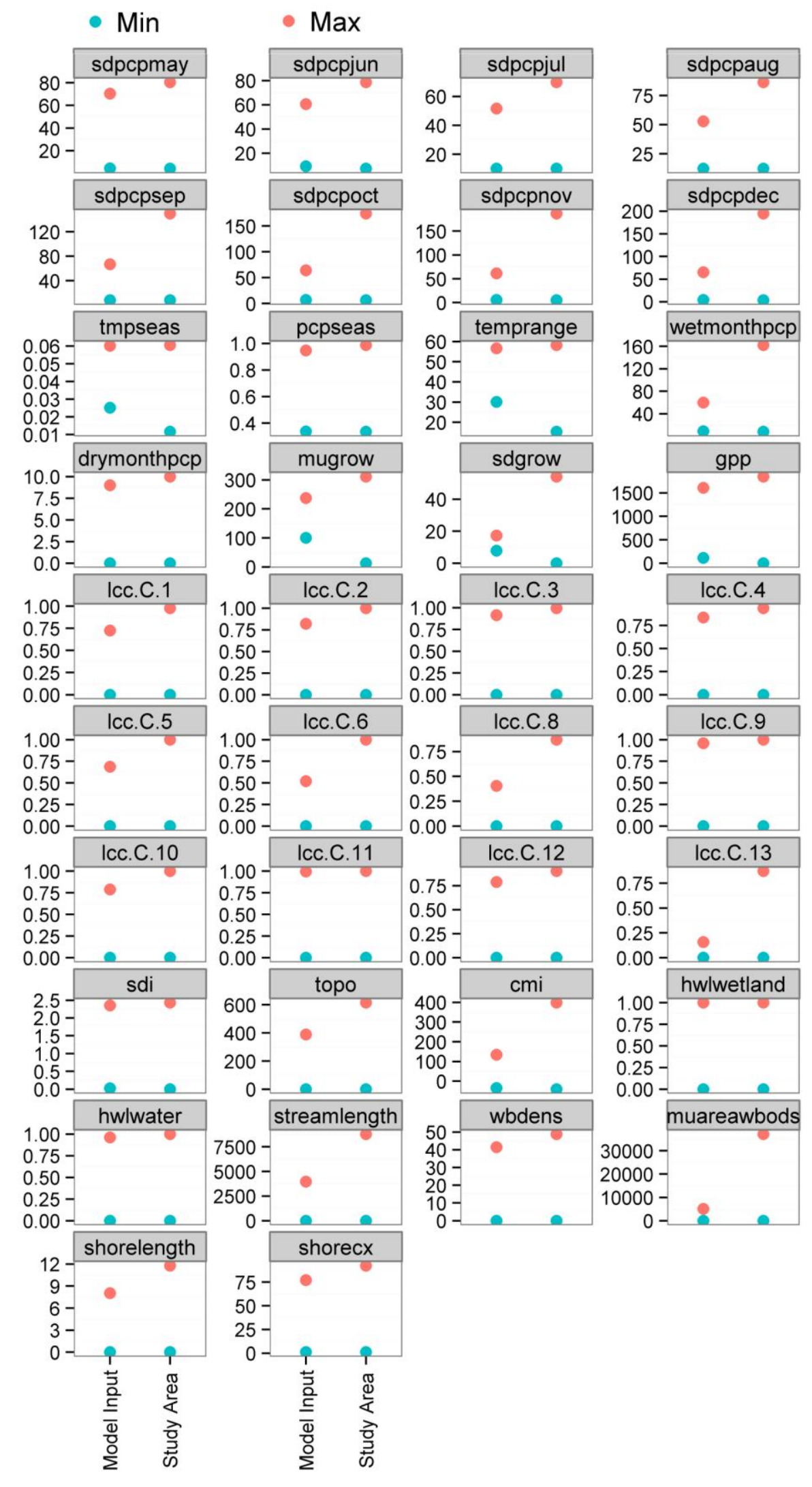


Appendix 2. Reclassification of Land Cover of Canada (2005)'s original 39 land cover classes to 16. Note that the following classes were excluded from the analyses to exclude duplication with other covariates or because of low values within the study area, although they were included in the calculation of SDI: burn (7), water (14), wetland/bog (15), and snow/ice (16).

\begin{tabular}{|c|c|c|}
\hline Reclass Name & Reclass Number & Original Class Name \\
\hline High density evergreen & 1 & $\begin{array}{l}\text { Temperate or subpolar needle-leaved evergreen closed tree } \\
\text { canopy }\end{array}$ \\
\hline \multirow{2}{*}{ Medium density evergreen } & \multirow{2}{*}{2} & $\begin{array}{l}\text { Temperate or subpolar needle-leaved evergreen medium } \\
\text { density, moss-shrub understory }\end{array}$ \\
\hline & & $\begin{array}{l}\text { Temperate or subpolar needle-leaved evergreen medium } \\
\text { density, lichen-shrub understory }\end{array}$ \\
\hline \multirow{4}{*}{ Low density evergreen } & \multirow{4}{*}{3} & $\begin{array}{l}\text { Temperate or subpolar needle-leaved evergreen low density, } \\
\text { shrub-moss understory }\end{array}$ \\
\hline & & $\begin{array}{l}\text { Temperate or subpolar needle-leaved evergreen low density, } \\
\text { lichen (rock) understory }\end{array}$ \\
\hline & & $\begin{array}{l}\text { Temperate or subpolar needle-leaved evergreen low density, } \\
\text { poorly drained }\end{array}$ \\
\hline & & Sparse needle-leaved evergreen, herb-shrub cover \\
\hline \multirow{3}{*}{ Deciduous } & \multirow{3}{*}{4} & Cold deciduous closed tree canopy \\
\hline & & Cold deciduous broad-leaved, low to medium density \\
\hline & & $\begin{array}{l}\text { Cold deciduous broad-leaved, medium density, young } \\
\text { regenerating }\end{array}$ \\
\hline \multirow[t]{2}{*}{ Mixed, deciduous-dominated } & \multirow[t]{2}{*}{5} & $\begin{array}{l}\text { Mixed cold deciduous - needle-leaved evergreen closed tree } \\
\text { canopy }\end{array}$ \\
\hline & & Low regenerating young mixed cover \\
\hline \multirow{4}{*}{ Mixed, evergreen-dominated } & \multirow{4}{*}{6} & $\begin{array}{l}\text { Mixed needle-leaved evergreen - cold deciduous closed tree } \\
\text { canopy }\end{array}$ \\
\hline & & $\begin{array}{l}\text { Mixed needle-leaved evergreen - cold deciduous closed young } \\
\text { tree canopy }\end{array}$ \\
\hline & & $\begin{array}{l}\text { Mixed needle-leaved evergreen - cold deciduous, low to } \\
\text { medium density }\end{array}$ \\
\hline & & needle-leaved evergreen, low to medium density \\
\hline \multirow{2}{*}{ Burn } & \multirow{2}{*}{7} & Recent burns \\
\hline & & Old burns \\
\hline \multirow[t]{2}{*}{ Shrubland } & \multirow[b]{2}{*}{8} & High-low shrub dominated \\
\hline & & Herb-shrub-bare cover \\
\hline
\end{tabular}




\begin{tabular}{|c|c|c|}
\hline Reclass Name & Reclass Number & Original Class Name \\
\hline \multirow{7}{*}{ Barren } & \multirow{7}{*}{10} & Polar grassland, herb-shrub \\
\hline & & Shrub-herb-lichen-bare \\
\hline & & Lichen-shrub-herb-bare soil \\
\hline & & Low vegetation cover \\
\hline & & Lichen barren \\
\hline & & Lichen-sedge-moss-low \\
\hline & & Rock outcrops \\
\hline \multirow{3}{*}{ Cropland } & \multirow{3}{*}{11} & High biomass cropland \\
\hline & & Medium biomass cropland \\
\hline & & Low biomass cropland \\
\hline Cropland-woodland & 12 & Cropland-woodland \\
\hline Urban & 13 & Urban and Built-up \\
\hline \multirow{2}{*}{ Water } & \multirow{2}{*}{14} & Water bodies \\
\hline & & Mixes of water and land \\
\hline \multirow{3}{*}{ Wetland/bog } & \multirow{3}{*}{15} & Herb-shrub poorly drained \\
\hline & & Wetlands \\
\hline & & Lichen-spruce bog \\
\hline Snow/lce & 16 & Snow or ice \\
\hline
\end{tabular}


Appendix 3. Assessment of spatial autocorrelation in BRT model residuals.

For each species, we tested for spatial autocorrelation by calculating Moran's I statistics on Pearson residuals. For BRT models, we calculated the residuals using the mean of 20 segment-level predictions, and corrected for the bootstrap variance. We also calculated Pearson residuals for a null model including only the mean effect. The "Null Ratio", which measures the reduction in spatial autocorrelation resulting from conditioning on model covariates, is calculated as the Moran's I statistic for the null model divided by that for the BRT models. In both cases, Moran's I was calculated over two distance bands, corresponding to the range of distances between adjacent segments $(20-50 \mathrm{~km})$ and between adjacent transects (30-120 $\mathrm{km})$.

\begin{tabular}{|c|c|c|c|c|}
\hline Species & Scale & Moran I Statistic & $p$-Value & Null Ratio \\
\hline ABDU & segment & 0.043 & 0.005 & 12.233 \\
\hline ABDU & transect & 0.022 & 0.001 & 22.634 \\
\hline AGWT & segment & 0.022 & 0.091 & 23.072 \\
\hline AGWT & transect & -0.009 & 0.887 & 43.500 \\
\hline AMWI & segment & 0.046 & 0.003 & 16.038 \\
\hline AMWI & transect & 0.018 & 0.003 & 35.358 \\
\hline BUFF & segment & 0.029 & 0.040 & 19.101 \\
\hline BUFF & transect & 0.006 & 0.154 & 65.070 \\
\hline BWTE & segment & 0.055 & 0.001 & 13.793 \\
\hline BWTE & transect & 0.037 & $<0.001$ & 18.998 \\
\hline CANV & segment & 0.046 & 0.003 & 11.356 \\
\hline CANV & transect & 0.015 & 0.010 & 26.021 \\
\hline GADW & segment & 0.096 & $<0.001$ & 7.299 \\
\hline GADW & transect & 0.042 & $<0.001$ & 15.183 \\
\hline GGOL & segment & -0.018 & 0.853 & 20.608 \\
\hline GGOL & transect & $<0.001$ & 0.468 & 2816.706 \\
\hline GMER & segment & -0.018 & 0.845 & 28.130 \\
\hline GMER & transect & -0.002 & 0.610 & 177.650 \\
\hline GSCA & segment & 0.039 & 0.011 & 13.840 \\
\hline GSCA & transect & 0.019 & 0.002 & 23.881 \\
\hline GSCO & segment & 0.016 & 0.171 & 54.310 \\
\hline GSCO & transect & 0.034 & $<0.001$ & 25.290 \\
\hline MALL & segment & 0.066 & $<0.001$ & 11.906 \\
\hline MALL & transect & 0.026 & $<0.001$ & 27.338 \\
\hline NOPI & segment & 0.104 & $<0.001$ & 7.041 \\
\hline NOPI & transect & 0.028 & $<0.001$ & 21.967 \\
\hline $\mathrm{NSHO}$ & segment & 0.061 & $<0.001$ & 11.688 \\
\hline $\mathrm{NSHO}$ & transect & 0.018 & 0.003 & 35.621 \\
\hline REDH & segment & 0.072 & $<0.001$ & 6.867 \\
\hline REDH & transect & 0.035 & $<0.001$ & 11.513 \\
\hline RNDU & segment & 0.024 & 0.074 & 15.842 \\
\hline RNDU & transect & 0.003 & 0.284 & 72.741 \\
\hline RUDU & segment & 0.039 & 0.010 & 5.979 \\
\hline RUDU & transect & 0.016 & 0.008 & 10.793 \\
\hline
\end{tabular}


Appendix 4. Individual species results.

For each species, we present three maps: 1) observed segment-level density from the WBPHS dataset; 2) mean predicted relative density per $\mathrm{km}^{2}$ with NatureServe range map (BirdLife International and NatureServe 2012; blue outline); and 3) coefficient of variation $(\mathrm{CV})$ of predicted abundance with an outline of the survey area as reference. We also present a table of the relative importance of environmental predictors. This relative importance table includes the mean and SD across 20 replicates for each variable, in descending order of importance (a percentage of 100), up to a cumulative sum of $80 \%$. For each species, we discuss our predicted distribution and influential predictor variables in relation to published range maps and habitat associations.

American Black Duck - ground nesting dabbling

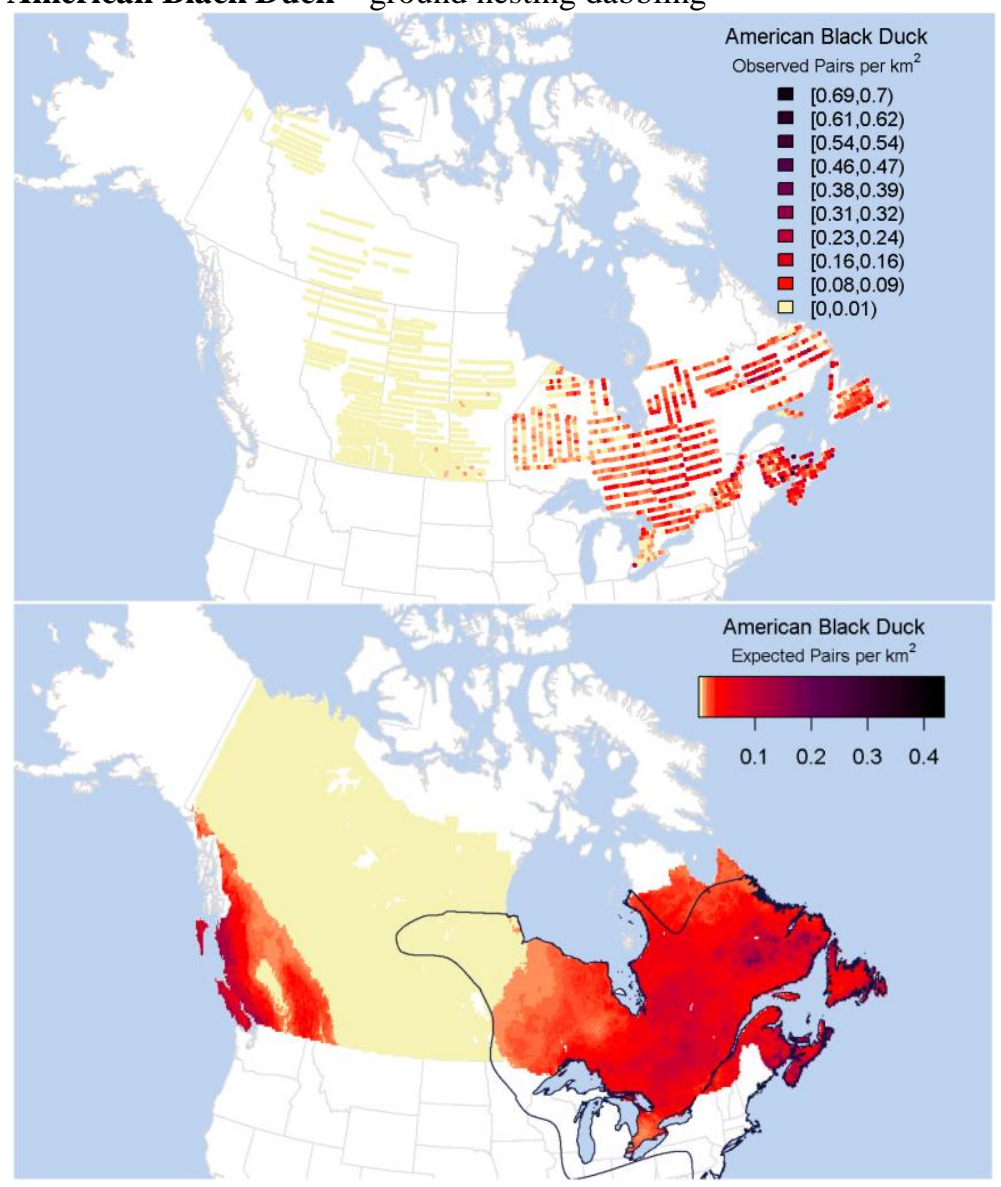




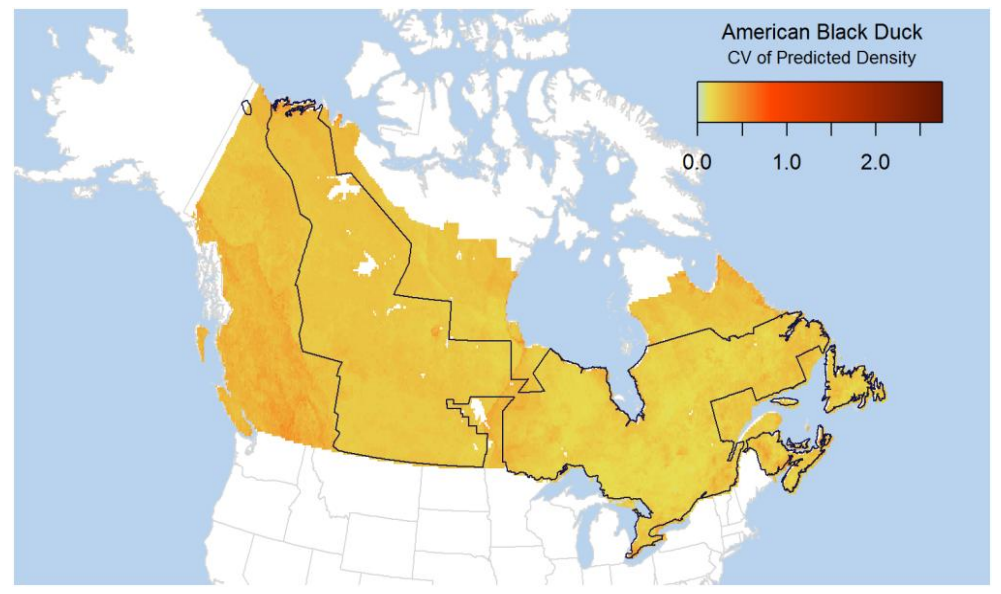

Our models predicted a relatively homogenous distribution of Black Ducks across eastern Canada, including the Boreal, Laurentians, and Great Lakes Lowlands, which is consistent with Longcore et al. (2000) and Johnsgard (2010). Our models also predicted relatively high densities on the west coast of Canada. We interpret these predictions as artefacts of extrapolation error from a model that does not incorporate biogeohistory of the Black Duck. This region of predicted high abundances outside of the Black Duck's range represents theoretically suitable habitat in an uninhabited area. The existence of a small, introduced population of American Black Ducks in southwest British Columbia on the mainland and Vancouver Island (Campbell et al. 1990, Longcore et al. 2000) suggests that this area represents suitable Black Duck habitat. See Model Limitations, in the Discussion for a thorough discussion of model limitations related to extrapolation.

$\begin{array}{lccc}\text { Variable } & \text { Mean \% } & \text { SD } & \text { Cumulative \% } \\ \text { Topographic Ruggedness } & 13.77 & 3.88 & 13.77 \\ \text { Mean Climate Moisture Index } & 7.24 & 2.37 & 21.01 \\ \text { Standard Deviation of Maximum Temperature in November } & 5.85 & 1.67 & 26.86 \\ \text { Mean Autumn Precipitation } & 5.67 & 1.93 & 32.53 \\ \text { \% Wetland (HWL) } & 3.14 & 0.95 & 35.68 \\ \text { Standard Deviation of Minimum Temperature in April } & 3.06 & 1.48 & 38.74 \\ \text { Standard Deviation of Maximum Temperature in February } & 2.77 & 1.16 & 41.51 \\ \text { Standard Deviation of Maximum Temperature in December } & 2.75 & 0.99 & 44.25 \\ \text { Standard Deviation of Minimum Temperature in February } & 2.38 & 0.99 & 46.63 \\ \text { Mean Waterbody Area (neighbourhood metric) } & 2.29 & 1.20 & 48.93 \\ \text { Standard Deviation of Precipitation in October } & 2.09 & 0.63 & 51.02 \\ \text { Mean Summer Precipitation } & 1.94 & 0.28 & 52.97 \\ \text { Standard Deviation of Maximum Temperature in August } & 1.93 & 1.14 & 54.90 \\ \text { Standard Deviation of Maximum Temperature in September } & 1.89 & 0.56 & 56.80 \\ \text { Standard Deviation of Maximum Temperature in March } & 1.70 & 0.44 & 58.49 \\ \text { Standard Deviation of Maximum Temperature in October } & 1.59 & 0.63 & 60.09 \\ \text { Mean Summer Maximum Temperature } & 1.58 & 0.71 & 61.67 \\ \text { Amount of Shoreline (km/km²) } & 1.56 & 0.49 & 63.22 \\ \text { Standard Deviation of Maximum Temperature in January } & 1.25 & 0.39 & 64.47 \\ \text { Standard Deviation of Precipitation in May } & 1.22 & 0.64 & 65.69 \\ \text { Standard Deviation of Maximum Temperature in June } & 1.10 & 0.70 & 66.79 \\ \text { Standard Deviation of Precipitation in December } & 1.09 & 0.28 & 67.88\end{array}$




$\begin{array}{llll}\text { Mean Summer Minimum Temperature } & 1.06 & 0.66 & 68.94 \\ \text { Mean Gross Primary Productivity } & 1.03 & 0.35 & 69.97 \\ \text { Standard Deviation of Maximum Temperature in April } & 1.02 & 0.47 & 70.99 \\ \text { Standard Deviation of Precipitation in April } & 0.96 & 0.23 & 71.95 \\ \text { Precipitation Seasonality } & 0.91 & 0.41 & 72.86 \\ \text { Standard Deviation of Minimum Temperature in October } & 0.90 & 0.38 & 73.76 \\ \text { Shannon's Diversity Index of Land Cover Types } & 0.84 & 0.37 & 74.60 \\ \text { Amount of Streams (km/km²) } & 0.78 & 0.27 & 75.38 \\ \text { Standard Deviation of Precipitation in August } & 0.78 & 0.53 & 76.16 \\ \text { Standard Deviation of Minimum Temperature in November } & 0.75 & 0.53 & 76.91 \\ \text { \% Cropland-woodland } & 0.75 & 0.60 & 77.66 \\ \text { \% Shrubland } & 0.74 & 0.24 & 78.40 \\ \text { Standard Deviation of Minimum Temperature in March } & 0.74 & 0.24 & 79.13 \\ \text { Mean Shoreline Complexity (neighbourhood metric) } & 0.73 & 0.19 & 79.86 \\ \text { Standard Deviation of Precipitation in March } & 0.72 & 0.24 & 80.58\end{array}$

Black Duck abundance was associated with topographic ruggedness, CMI, variability in maximum November temperature, mean autumn precipitation, and amount of wetland. The top four of these variables may capture the species' eastern-restricted distribution, while the amount of wetland represents the species' association with water. Black Ducks are reported to nest in most wetland types, including coastal marshes, beaver ponds, and boreal bogs (Longcore et al. 2000, Johnsgard 2010). Given this wide range in habitat suitability, along with the eastern-restricted range, most of the most important variables likely capture the spatial correlation rather than a mechanistic association with any given habitat type or limiting factor. 
Green-winged Teal - ground nesting dabbling

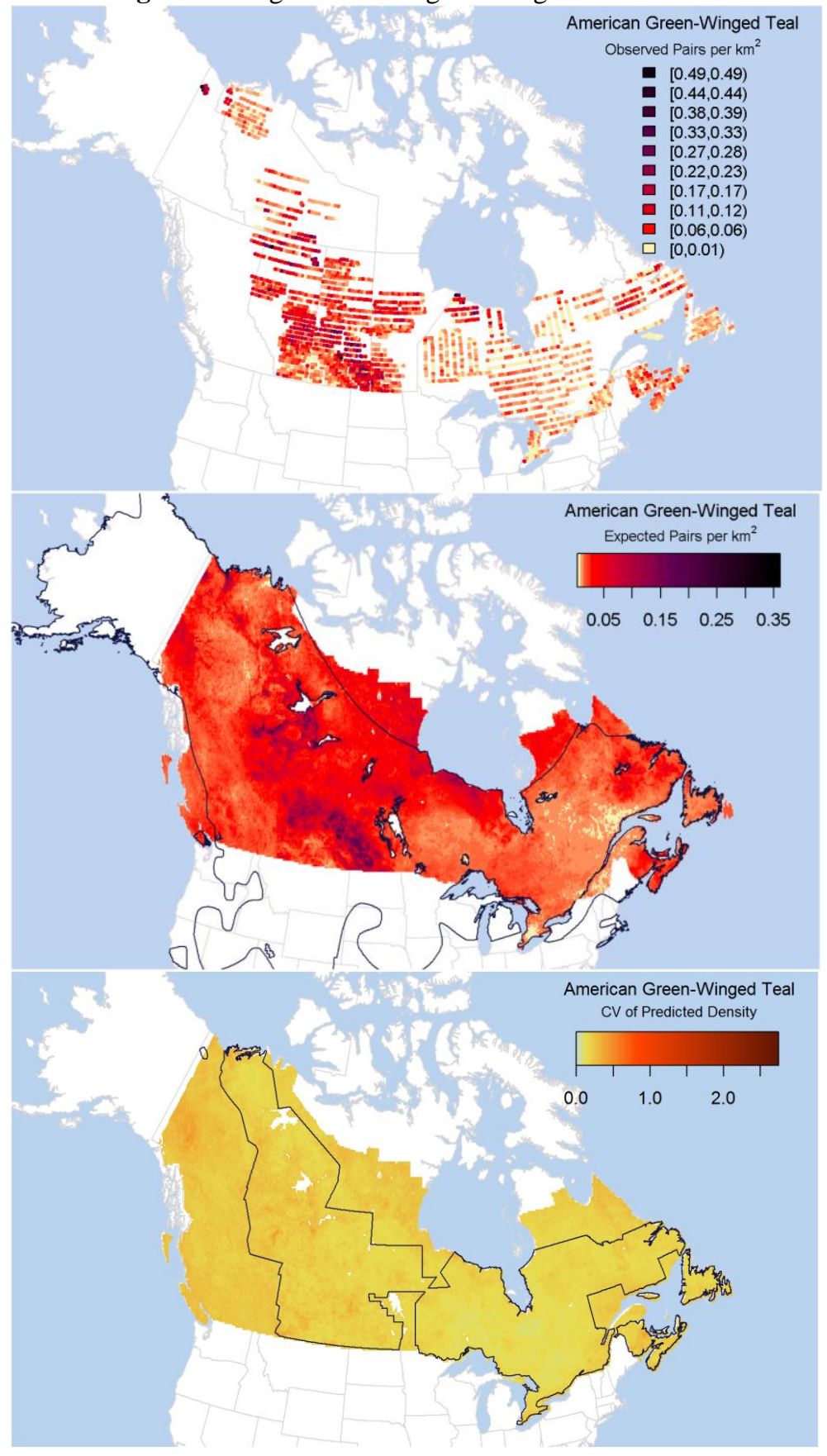

Our models predicted the highest densities of Green-winged Teal in the aspen parkland, the Peace-Athabasca Delta, and the Slave River Lowlands, consistent with Johnsgard (2010). Lower densities were observed in the prairies, which is consistent with a reported avoidance of eutrophic, agricultural lakes in favour of wooded ponds of the aspen parkland (Moisan et al. 1967). Our observed distribution extended well north of published ranges 
(Johnsgard 2010, BirdLife International and NatureServe 2012), but these areas were partly extrapolations beyond the survey area (see Model Limitations, in Discussion).

\begin{tabular}{|c|c|c|c|}
\hline Variable & Mean \% & SD & Cumulative \% \\
\hline Mean Climate Moisture Index & 7.82 & 1.26 & 7.82 \\
\hline Density of Waterbodies (neighbourhood metric) & 6.67 & 1.16 & 14.49 \\
\hline Precipitation Seasonality & 3.31 & 0.63 & 17.79 \\
\hline Mean Gross Primary Productivity & 3.17 & 0.65 & 20.96 \\
\hline Standard Deviation of Maximum Temperature in March & 2.75 & 0.87 & 23.71 \\
\hline Amount of Streams $\left(\mathrm{km} / \mathrm{km}^{2}\right)$ & 2.68 & 0.77 & 26.39 \\
\hline Standard Deviation of Maximum Temperature in October & 2.66 & 0.61 & 29.05 \\
\hline Amount of Shoreline $\left(\mathrm{km} / \mathrm{km}^{2}\right)$ & 2.57 & 0.78 & 31.61 \\
\hline \% Cropland-woodland & 2.53 & 0.67 & 34.14 \\
\hline Topographic Ruggedness & 2.50 & 0.57 & 36.64 \\
\hline$\%$ Deciduous Forest & 2.44 & 0.70 & 39.09 \\
\hline Standard Deviation of Minimum Temperature in November & 2.41 & 0.61 & 41.49 \\
\hline Standard Deviation of Maximum Temperature in December & 2.36 & 0.72 & 43.86 \\
\hline Standard Deviation of Maximum Temperature in September & 2.13 & 0.64 & 45.99 \\
\hline Standard Deviation of Precipitation in August & 1.78 & 0.53 & 47.77 \\
\hline Mean Spring Maximum Temperature & 1.78 & 0.59 & 49.55 \\
\hline Standard Deviation of Growing Season Length & 1.78 & 0.38 & 51.32 \\
\hline Standard Deviation of Minimum Temperature in June & 1.73 & 0.48 & 53.05 \\
\hline$\%$ Wetland (HWL) & 1.69 & 0.33 & 54.74 \\
\hline Standard Deviation of Precipitation in October & 1.55 & 0.53 & 56.29 \\
\hline Mean Shoreline Complexity (neighbourhood metric) & 1.36 & 0.24 & 57.65 \\
\hline Standard Deviation of Minimum Temperature in January & 1.34 & 0.48 & 58.99 \\
\hline Mean Autumn Maximum Temperature & 1.33 & 0.49 & 60.32 \\
\hline Standard Deviation of Precipitation in December & 1.33 & 0.46 & 61.65 \\
\hline Mean Spring Precipitation & 1.31 & 0.47 & 62.97 \\
\hline \% Open Water (HWL) & 1.29 & 0.30 & 64.26 \\
\hline Mean Summer Precipitation & 1.25 & 0.40 & 65.51 \\
\hline Mean Autumn Minimum Temperature & 1.25 & 0.41 & 66.76 \\
\hline Standard Deviation of Maximum Temperature in February & 1.23 & 0.54 & 67.99 \\
\hline Standard Deviation of Minimum Temperature in March & 1.17 & 0.40 & 69.16 \\
\hline Mean Summer Maximum Temperature & 1.13 & 0.35 & 70.29 \\
\hline Standard Deviation of Maximum Temperature in January & 1.12 & 0.30 & 71.41 \\
\hline Standard Deviation of Maximum Temperature in August & 1.08 & 0.38 & 72.49 \\
\hline Standard Deviation of Minimum Temperature in December & 1.07 & 0.30 & 73.56 \\
\hline$\%$ Shrubland & 1.05 & 0.37 & 74.61 \\
\hline Annual Range in Temperature & 0.99 & 0.25 & 75.60 \\
\hline Standard Deviation of Precipitation in September & 0.98 & 0.23 & 76.58 \\
\hline$\%$ Cropland & 0.90 & 0.28 & 77.48 \\
\hline Mean Waterbody Area (neighbourhood metric) & 0.89 & 0.30 & 78.38 \\
\hline Standard Deviation of Maximum Temperature in April & 0.87 & 0.28 & 79.25 \\
\hline \% Mixed Forest - Deciduous-dominated & 0.87 & 0.26 & 80.11 \\
\hline
\end{tabular}

Green-winged Teal abundance was most closely associated with climate moisture index (CMI) and segmentlevel water body density. The next two most important covariates were precipitation seasonality and gross 
primary productivity (GPP). CMI may play a role in isolating the aspen parkland, where highest densities occurred, from the drier prairies to the south and the more western boreal to the North. The relationship with water body density is consistent with (Johnson and Grier 1988), and may also represent selection for smaller water bodies, as reported by Toft et al. (1982), Décarie et al. (1995), Rempel et al. (1997), and Kindopp (2002). This association with water body density may also represent a spatial rather than biological relationship, since this variable appeared higher in the aspen parkland than the surrounding areas, when assessed visually. The sixth most important variable was stream length, which is consistent with Lemelin et al. (2010)'s finding that the species prefers moving water to lakes or ponds. Even the top variables showed low relative importance, which agrees with previous findings that this species shows few and weak habitat associations (Kindopp 2002). At the individual wetland scale used by Kindopp (2002), this result may indicate flexibility in habitat selection (Johnson 1995, Nummi and Pöysä 1997). At large scales such as in our study, it also likely represents the extremely broad distribution with homogenous abundance across much of the species' range (Johnsgard 2010). Most of the broadly-distributed species we studied exhibited the same pattern, where top predictor variables had lower relative importance, or explanatory power, than the top variables for narrowly-distributed species. 
American Wigeon - ground nesting dabbling

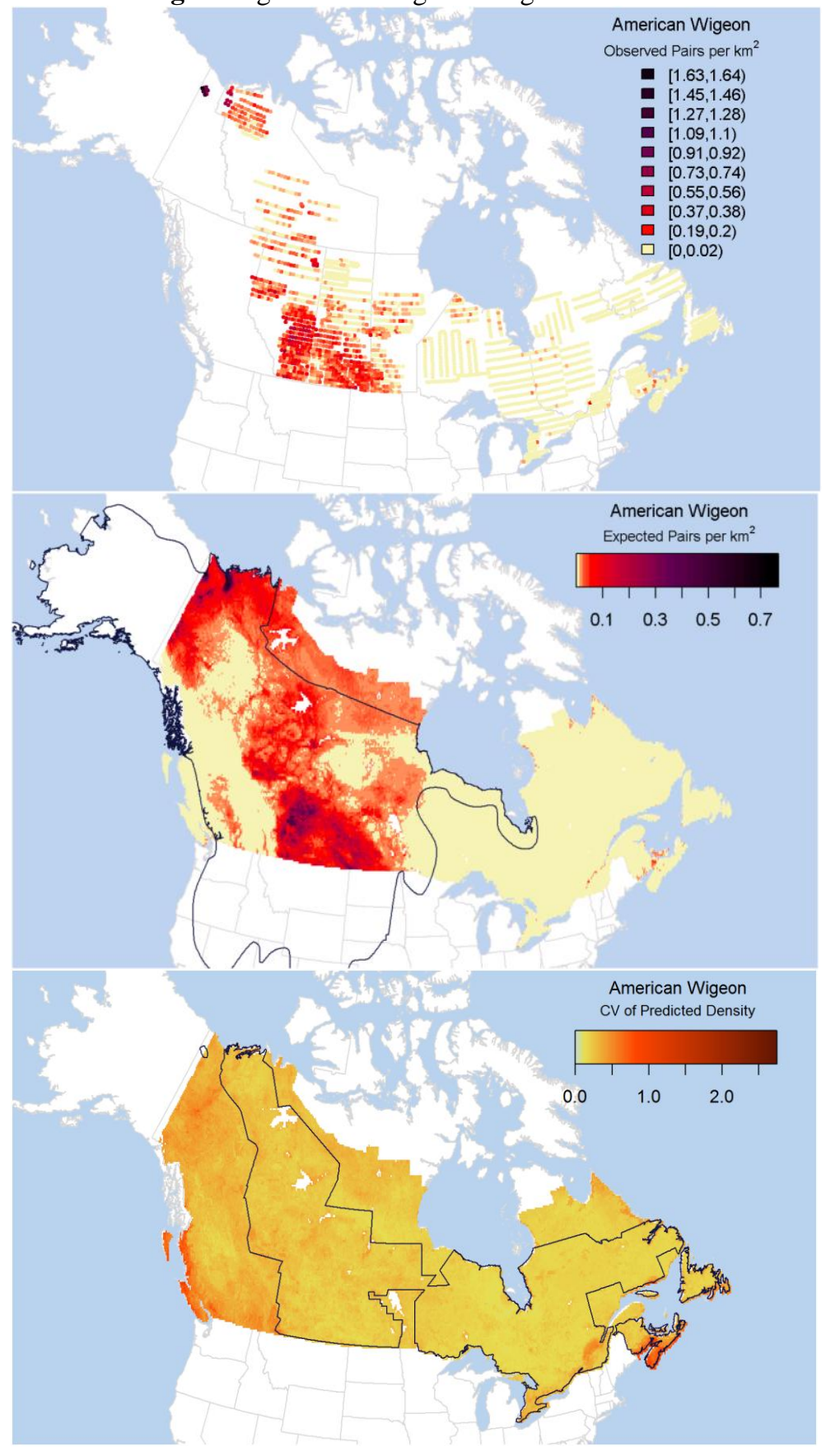

Our models predicted high abundances of American Wigeon in the prairie-parkland and throughout the western boreal forest, with the highest densities in the prairie-parkland region and the MacKenzie Delta. While this is generally consistent with published range maps (Johnsgard 2010, BirdLife International and NatureServe 2012), our predictions extended beyond the recognized northern limits, though these areas were partly extrapolations. 
Our maps also predict limited abundances in Eastern Canada, while the NatureServe range excludes most of this region. These eastern predictions are consistent with observations from the WBPHS and from the Breeding Bird Atlases of Ontario and Québec (Bird Studies Canada et al. 2009, Regroupement QuébecOiseaux et al. 2014).

$\begin{array}{lccc}\text { Variable } & \text { Mean \% } & \text { SD } & \text { Cumulative \% } \\ \text { Standard Deviation of Minimum Temperature in October } & 12.36 & 4.02 & 12.36 \\ \text { Standard Deviation of Maximum Temperature in September } & 10.76 & 1.99 & 23.12 \\ \text { Amount of Shoreline }\left(\mathrm{km}^{\prime} / \mathrm{km}^{2}\right) & 6.92 & 1.52 & 30.04 \\ \text { Mean Climate Moisture Index } & 4.40 & 0.73 & 34.44 \\ \text { Mean Autumn Precipitation } & 4.22 & 1.82 & 38.66 \\ \text { Standard Deviation of Growing Season Length } & 3.77 & 0.93 & 42.42 \\ \text { \% Open Water (HWL) } & 3.44 & 1.07 & 45.86 \\ \text { Density of Waterbodies (neighbourhood metric) } & 3.10 & 0.80 & 48.96 \\ \text { Precipitation Seasonality } & 3.04 & 0.96 & 52.00 \\ \text { \% Cropland } & 2.92 & 0.76 & 54.91 \\ \text { Topographic Ruggedness } & 2.38 & 0.67 & 57.30 \\ \text { Standard Deviation of Maximum Temperature in January } & 2.10 & 0.63 & 59.40 \\ \text { Standard Deviation of Precipitation in April } & 1.96 & 1.00 & 61.36 \\ \text { Standard Deviation of Minimum Temperature in April } & 1.93 & 1.06 & 63.29 \\ \text { Standard Deviation of Maximum Temperature in October } & 1.40 & 0.93 & 64.68 \\ \text { Standard Deviation of Maximum Temperature in February } & 1.37 & 1.01 & 66.05 \\ \text { Mean Winter Precipitation } & 1.28 & 0.47 & 67.33 \\ \text { Standard Deviation of Minimum Temperature in February } & 1.19 & 0.69 & 68.52 \\ \text { \% Shrubland } & 1.19 & 0.64 & 69.71 \\ \text { Standard Deviation of Minimum Temperature in September } & 1.11 & 0.58 & 70.82 \\ \text { Standard Deviation of Maximum Temperature in November } & 1.09 & 0.42 & 71.91 \\ \text { Standard Deviation of Maximum Temperature in May } & 1.09 & 0.62 & 73.00 \\ \text { Mean Gross Primary Productivity } & 1.05 & 0.29 & 74.05 \\ \text { Standard Deviation of Precipitation in October } & 0.99 & 0.41 & 75.05 \\ \text { Mean Summer Maximum Temperature } & 0.95 & 0.35 & 75.99 \\ \text { Standard Deviation of Maximum Temperature in December } & 0.91 & 0.31 & 76.91 \\ \text { Shannon's Diversity Index of Land Cover Types } & 0.88 & 0.22 & 77.79 \\ \text { \% Cropland-woodland } & 0.86 & 0.21 & 78.64 \\ \text { Standard Deviation of Maximum Temperature in August } & 0.84 & 0.16 & 79.49 \\ \text { Standard Deviation of Maximum Temperature in March } & 0.76 & 0.39 & 80.25\end{array}$

American Wigeon abundance was most closely associated with variability in minimum October temperature and maximum September temperature, as well as amount of shoreline and CMI. The bioclimatic variables likely capture the large-scale spatial pattern of abundance. The seventh and eighth most important variables were amount of open water and water body density. In association with the amount of shoreline, these variables capture the relationship of American Wigeon to water. In particular, the amount of open water may relate to the American Wigeon's use of more open water for feeding, compared to other Anas species (Johnsgard 2010). 
Blue-winged Teal - ground nesting dabbling

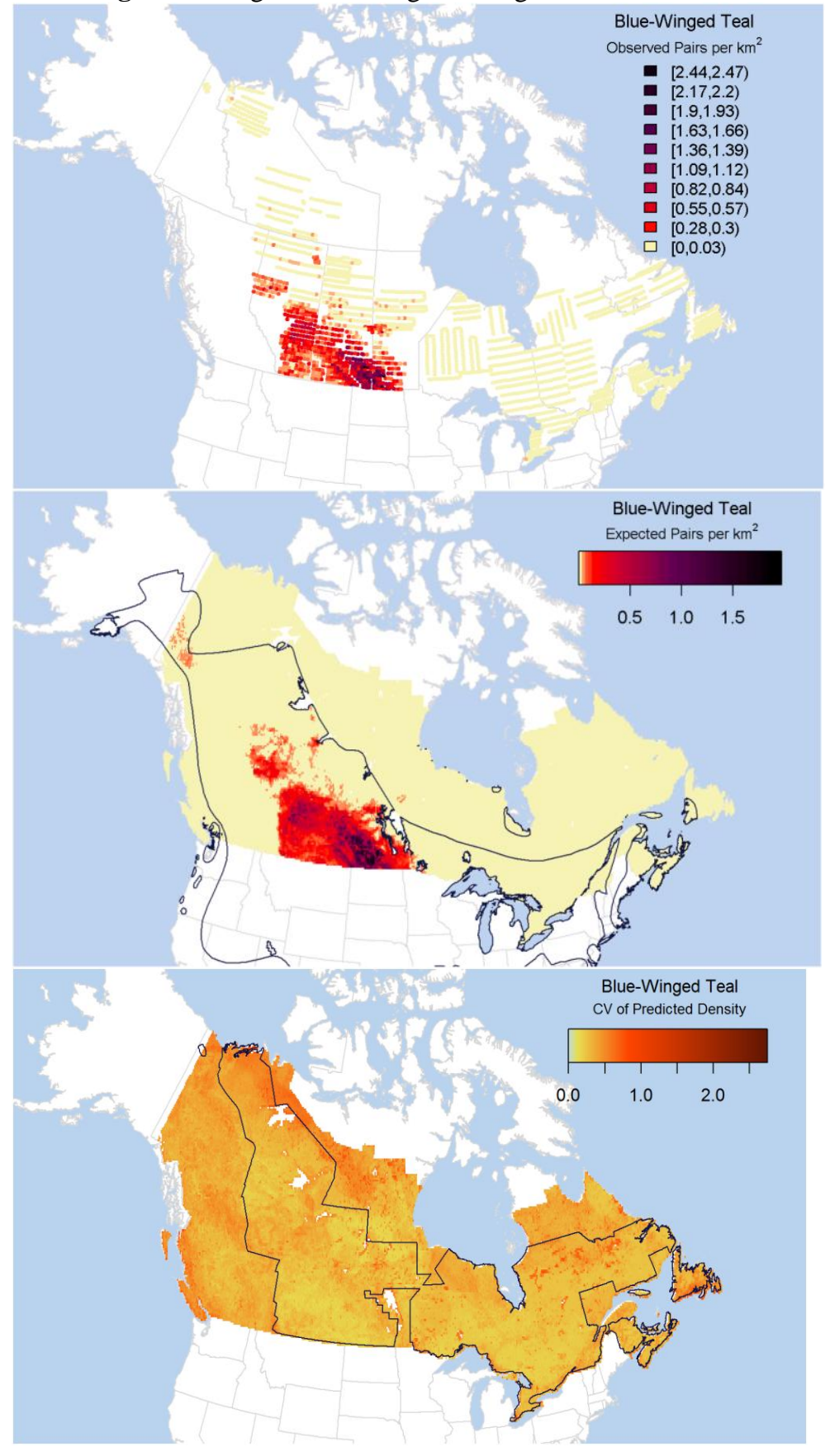

Our models predicted high densities of Blue-winged Teal concentrated in the prairie-parkland region and lower densities elsewhere. This pattern is generally consistent with Johnson and Grier (1988). NatureServe (BirdLife International and NatureServe 2012) and Johnsgard (2010) suggest a larger range than depicted in our map, but Johnsgard highlights that the species is not a common breeder outside of the prairies. Our map therefore 
highlights the difference in abundances within and outside of the core breeding area. The map of raw observations suggest that Blue-winged Teals inhabit southern Ontario, which is consistent with the Breeding Bird Atlas of Ontario (Bird Studies Canada et al. 2009) and the NatureServe range map. Our model, however, predicted very low abundances (effectively absence) of Blue-winged Teals within southern Ontario. There may be insufficient data within the survey to allow the model to accurately predict Blue-Winged Teals in this location.

$\begin{array}{lccc}\text { Variable } & \text { Mean \% } & \text { SD } & \text { Cumulative \% } \\ \text { \% Cropland } & 24.92 & 2.53 & 24.92 \\ \text { Density of Waterbodies (neighbourhood metric) } & 10.34 & 2.94 & 35.26 \\ \text { Amount of Shoreline }\left(\mathrm{km}^{\prime} \mathrm{km}^{2}\right) & 8.08 & 2.21 & 43.34 \\ \text { Standard Deviation of Minimum Temperature in June } & 6.22 & 1.92 & 49.57 \\ \text { Mean Climate Moisture Index } & 6.06 & 1.75 & 55.63 \\ \text { Standard Deviation of Precipitation in August } & 3.12 & 1.29 & 58.75 \\ \text { Standard Deviation of Maximum Temperature in August } & 3.12 & 1.48 & 61.87 \\ \text { Precipitation Seasonality } & 2.94 & 0.56 & 64.81 \\ \text { Standard Deviation of Maximum Temperature in April } & 2.12 & 1.29 & 66.93 \\ \text { \% Open Water (HWL) } & 1.97 & 0.60 & 68.90 \\ \text { Topographic Ruggedness } & 1.82 & 0.38 & 70.72 \\ \text { Amount of Streams (km/km²) } & 1.39 & 0.36 & 72.11 \\ \text { Standard Deviation of Precipitation in December } & 1.36 & 0.74 & 73.47 \\ \text { Standard Deviation of Maximum Temperature in June } & 1.25 & 0.88 & 74.72 \\ \text { \% Deciduous Forest } & 1.23 & 0.27 & 75.95 \\ \text { Standard Deviation of Precipitation in November } & 1.22 & 1.13 & 77.18 \\ \text { \% Cropland-woodland } & 1.18 & 0.31 & 78.36 \\ \text { Standard Deviation of Minimum Temperature in May } & 1.14 & 0.74 & 79.49 \\ \text { Standard Deviation of Precipitation in October } & 1.13 & 0.72 & 80.63\end{array}$

Abundance of Blue-winged Teal was most closely associated with amount of cropland, followed by water body density, amount of shoreline, and the standard deviation of minimum June temperature. The most important variable contrasts with Rohwer et al. (2002)'s suggestion that Blue-winged Teals prefer grassland over cropland. However, we suspect that at the scale of our study, cropland was associated with grassland habitat and pothole type wetlands. Therefore, the amount of cropland likely acted as a proxy, capturing the high abundance of Bluewinged Teal within the prairie-parkland and low abundance elsewhere. The association with water body density and amount of shoreline may relate to the species' dependence on small, shallow, and productive wetlands Rohwer et al. (2002), though it could also represent a spatial association of the species with the aspen parklands of Saskatchewan and Manitoba where the species was most abundant. 
Gadwall - ground nesting dabbling

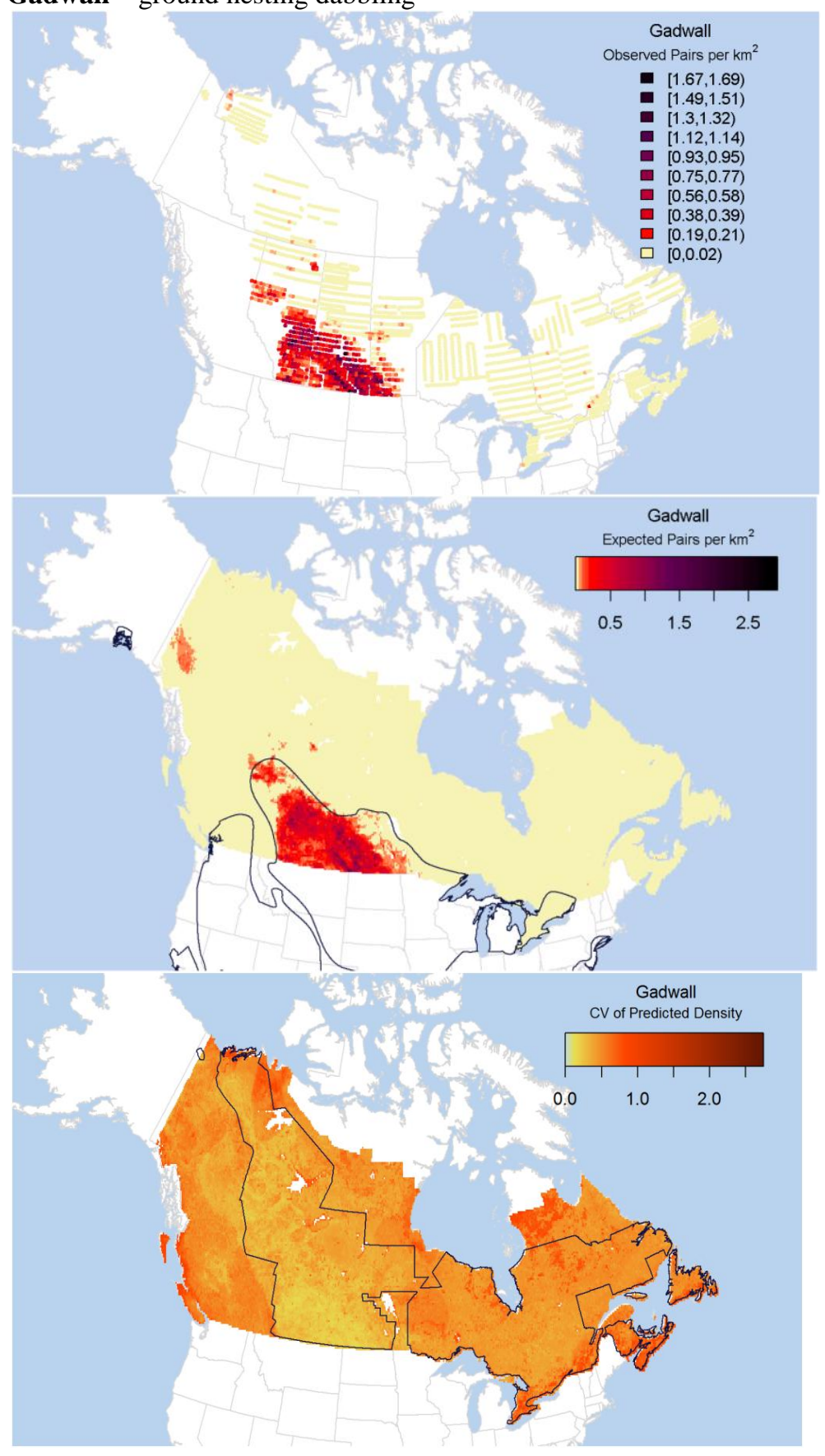

Our models predicted apparently high densities of Gadwall concentrated in the prairie-parkland region, and lower densities elsewhere, which is consistent with published range maps (Johnson and Grier 1988, Johnsgard 2010, BirdLife International and NatureServe 2012). 


$\begin{array}{lccc}\text { Variable } & \text { Mean \% } & \text { SD } & \text { Cumulative \% } \\ \text { \% Cropland } & 29.77 & 2.64 & 29.77 \\ \text { \% Open Water (HWL) } & 11.22 & 1.42 & 40.99 \\ \text { Mean Climate Moisture Index } & 9.04 & 2.90 & 50.03 \\ \text { Amount of Shoreline (km/km²) } & 6.09 & 1.83 & 56.12 \\ \text { Precipitation Seasonality } & 5.06 & 1.42 & 61.18 \\ \text { Density of Waterbodies (neighbourhood metric) } & 3.21 & 1.20 & 64.39 \\ \text { Standard Deviation of Maximum Temperature in August } & 2.86 & 1.25 & 67.25 \\ \text { Amount of Streams (km/km²) } & 2.46 & 0.91 & 69.71 \\ \text { Standard Deviation of Maximum Temperature in September } & 2.10 & 0.64 & 71.81 \\ \text { \% Cropland-woodland } & 1.58 & 0.25 & 73.38 \\ \text { \% Wetland (HWL) } & 1.13 & 0.17 & 74.52 \\ \text { Topographic Ruggedness } & 1.06 & 0.17 & 75.58 \\ \text { Mean Gross Primary Productivity } & 1.04 & 0.34 & 76.61 \\ \text { Standard Deviation of Precipitation in October } & 0.93 & 0.53 & 77.55 \\ \text { Mean Shoreline Complexity (neighbourhood metric) } & 0.93 & 0.25 & 78.48 \\ \text { Standard Deviation of Precipitation in July } & 0.90 & 0.41 & 79.37 \\ \text { Shannon's Diversity Index of Land Cover Types } & 0.85 & 0.22 & 80.22\end{array}$

Gadwall abundance was most closely associated with amount of cropland, followed by amount of open water and CMI. As with Blue-winged Teals, Gadwalls avoid cropland in favour of untilled upland (Higgins 1977), but at our study's scale and resolution, this positive association with cropland likely represents a continental spatial association with the prairie-parklands rather than actual selection for cropland habitat. CMI may separate the prairies from the parkland via a negative water balance. A positive association with open water may reflect the preference of Gadwall for wetlands comprised of 50:50 water to emergent vegetation compared to those with more vegetation (Kaminski and Prince 1981). 
Mallard - ground nesting dabbling

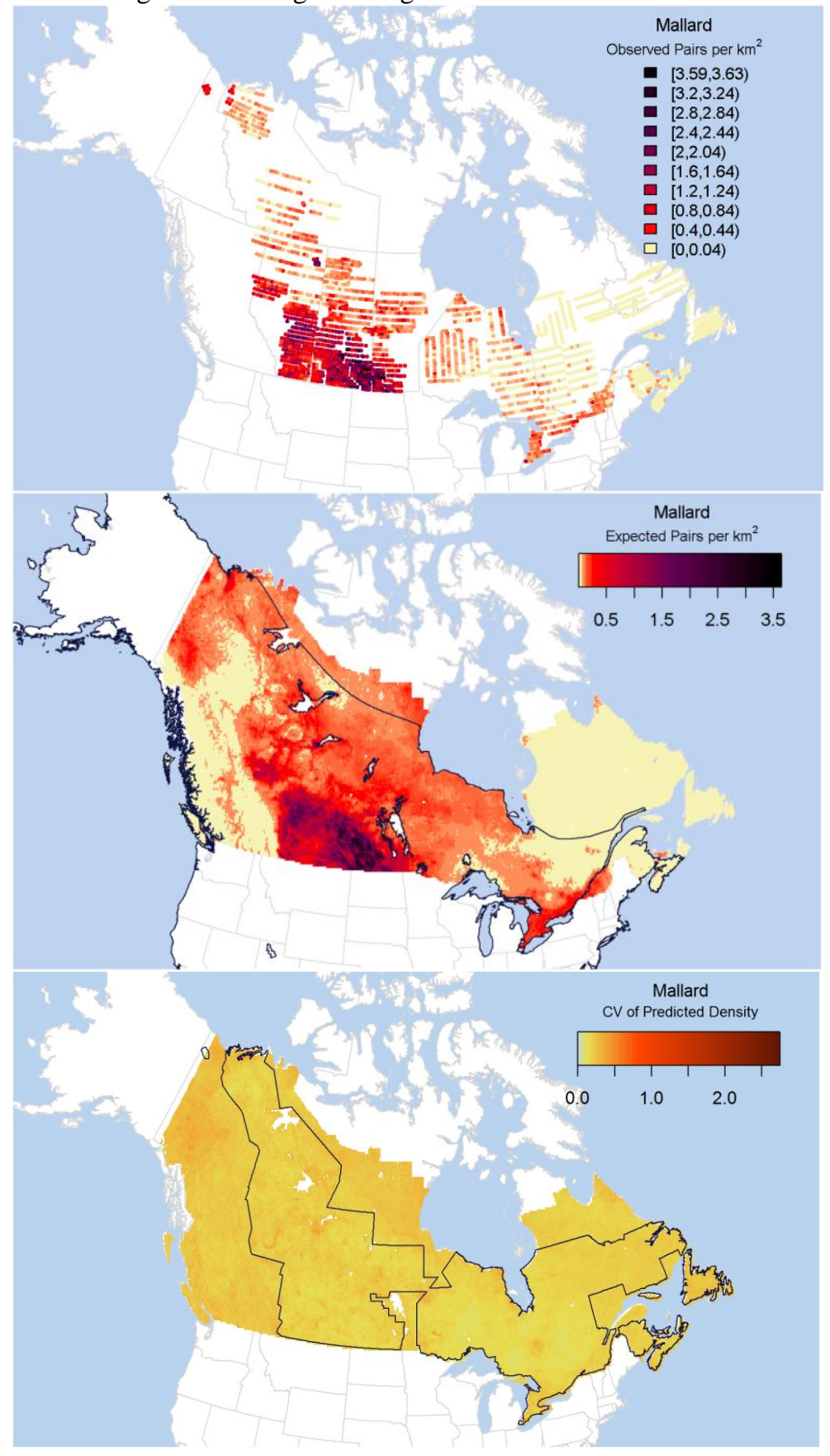

Our models predicted high densities of Mallards in the prairie-parkland region, and throughout the PeaceAthabasca Delta, the Slave River Lowlands, and the Great Lakes Lowlands. Pockets of relatively high density were also predicted in the MacKenzie Delta and in southern Yukon. The overall range appears similar to 
published accounts (Johnsgard 2010, BirdLife International and NatureServe 2012), including the fact that highest densities are reported in the prairie-parkland region (Drilling et al. 2002).

$\begin{array}{lccc}\text { Variable } & \text { Mean \% } & \text { SD } & \text { Cumulative \% } \\ \text { \% Cropland } & 41.50 & 1.88 & 41.50 \\ \text { Amount of Shoreline (km/km²) } & 6.29 & 1.50 & 47.79 \\ \text { Density of Waterbodies (neighbourhood metric) } & 5.38 & 1.37 & 53.17 \\ \text { Mean Climate Moisture Index } & 3.65 & 1.46 & 56.82 \\ \text { Precipitation Seasonality } & 3.56 & 1.16 & 60.38 \\ \text { \% Open Water (HWL) } & 3.17 & 0.73 & 63.55 \\ \text { Standard Deviation of Minimum Temperature in June } & 2.73 & 1.23 & 66.28 \\ \text { Standard Deviation of Maximum Temperature in August } & 1.89 & 1.01 & 68.17 \\ \text { \% Cropland-woodland } & 1.76 & 0.29 & 69.93 \\ \text { Topographic Ruggedness } & 1.74 & 0.55 & 71.67 \\ \text { Standard Deviation of Maximum Temperature in April } & 1.27 & 0.49 & 72.93 \\ \text { Amount of Streams (km/km²) } & 1.22 & 0.46 & 74.15 \\ \text { Standard Deviation of Maximum Temperature in June } & 1.13 & 0.54 & 75.29 \\ \text { Standard Deviation of Precipitation in August } & 1.00 & 0.62 & 76.28 \\ \text { \% Wetland (HWL) } & 0.96 & 0.15 & 77.24 \\ \text { \% Deciduous Forest } & 0.96 & 0.20 & 78.20 \\ \text { Mean Spring Maximum Temperature } & 0.75 & 0.29 & 78.95 \\ \text { Mean Summer Minimum Temperature } & 0.72 & 0.15 & 79.67 \\ \text { Shannon's Diversity Index of Land Cover Types } & 0.70 & 0.18 & 80.37\end{array}$

As with other dabbling species, Mallard abundance was associated with amount of cropland, amount of shoreline, water body density, and CMI. These variables seem to best explain high abundances in the prairieparkland region and lower abundances in the surrounding area. The amount of shoreline and water body density may also relate to Mallards' preference for shallow wetlands (Stewart and Kantrud 1973). The association with cropland may or may not represent a biological correspondence in this case since Mallards prefer to nest in tall vegetation, including hayfields (Johnsgard 2010), but also reportedly avoid nesting in cropland (Greenwood et al. 1995). The sixth most important variable was the amount of open water, which may reflect the preference of Mallards for more open water areas in the boreal forest (Drilling et al. 2002). 
Northern Pintail - ground nesting dabbling

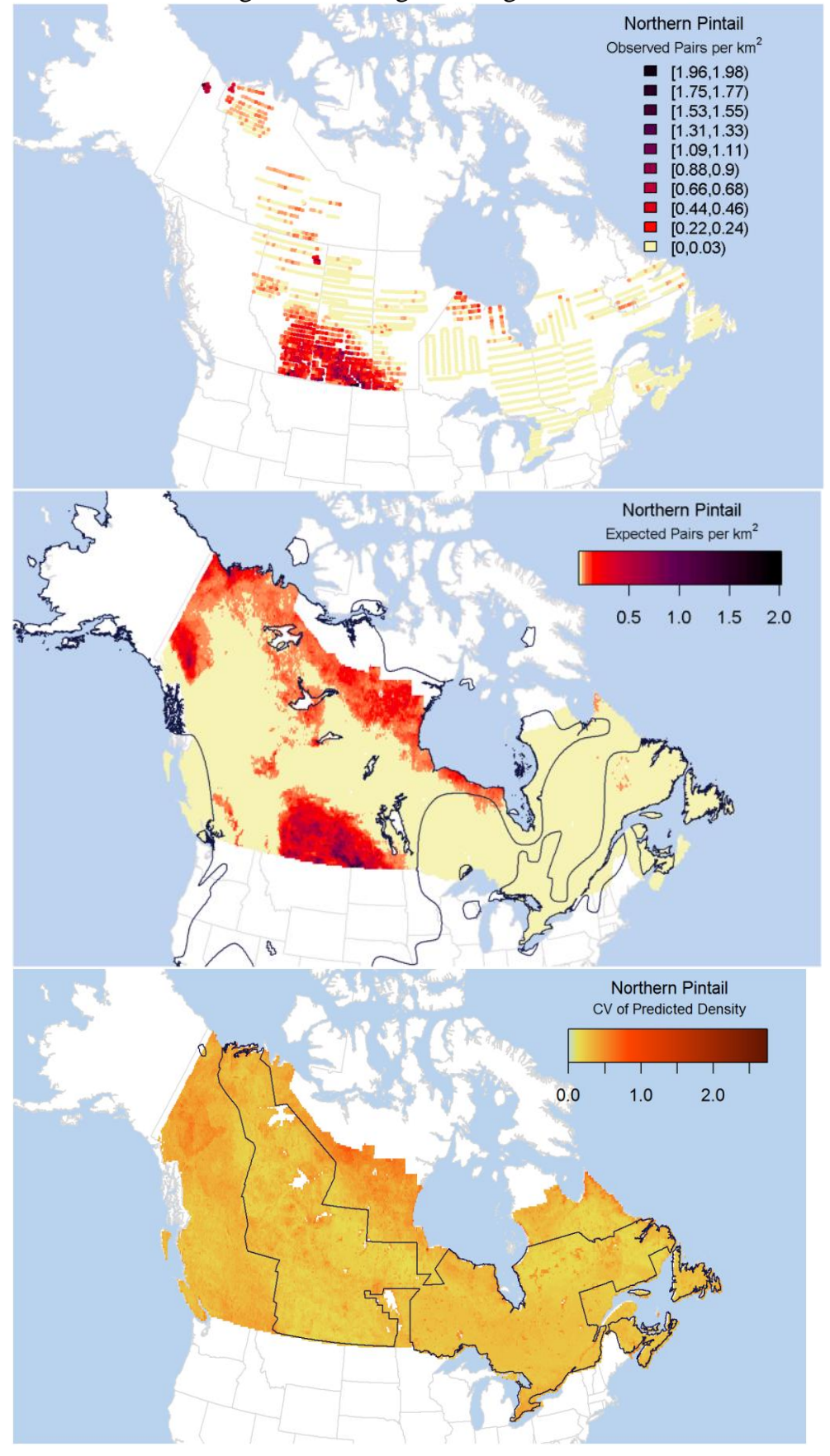

Our models predicted high densities of Pintails in the prairies but also in the Yukon, along the northern limits of our study area, and among some of the parkland areas. Johnsgard (2010) classified Pintails as a low Arctic species, likely reflecting its high abundance in Alaska, which is consistent with our predictions of the species 
living in the North. That the species is abundant in the prairies is also consistent with Johnson and Grier (1988) and Johnsgard (2010).

$\begin{array}{lccc}\text { Variable } & \text { Mean \% } & \text { SD } & \text { Cumulative \% } \\ \text { Mean Climate Moisture Index } & 36.31 & 2.52 & 36.31 \\ \text { Amount of Shoreline }\left(\mathrm{km}^{\mathrm{k}} \mathrm{km}^{2}\right) & 7.72 & 1.86 & 44.03 \\ \text { \% Cropland } & 5.43 & 1.48 & 49.46 \\ \text { Standard Deviation of Minimum Temperature in November } & 4.99 & 1.60 & 54.45 \\ \text { Topographic Ruggedness } & 3.97 & 0.62 & 58.41 \\ \text { Standard Deviation of Maximum Temperature in September } & 3.40 & 1.28 & 61.81 \\ \text { \% Open Water (HWL) } & 2.94 & 0.83 & 64.75 \\ \text { Standard Deviation of Maximum Temperature in August } & 2.06 & 0.57 & 66.82 \\ \text { Density of Waterbodies (neighbourhood metric) } & 1.95 & 0.72 & 68.76 \\ \text { Standard Deviation of Maximum Temperature in February } & 1.87 & 0.52 & 70.64 \\ \text { Mean Winter Precipitation } & 1.64 & 0.46 & 72.28 \\ \text { Standard Deviation of Precipitation in October } & 1.58 & 0.70 & 73.85 \\ \text { Amount of Streams (km/km²) } & 1.27 & 0.34 & 75.12 \\ \text { Standard Deviation of Minimum Temperature in February } & 1.24 & 0.66 & 76.36 \\ \text { Standard Deviation of Maximum Temperature in October } & 1.08 & 0.33 & 77.44 \\ \text { Standard Deviation of Maximum Temperature in July } & 1.03 & 0.33 & 78.46 \\ \text { \% Cropland-woodland } & 0.95 & 0.15 & 79.41 \\ \text { Standard Deviation of Maximum Temperature in November } & 0.92 & 0.42 & 80.33\end{array}$

Pintail abundance was most closely associated with CMI, followed by amount of shoreline, amount of cropland, two temperature variability measures (November and September), and topographic ruggedness. As with other dabblers, the high abundance of the species in the western prairies likely explains the association with the former three variables. The Pintail reportedly has a stronger dependence on open habitats than other dabblers (Johnsgard 2010), which is reflected in higher abundances in the prairies. This pattern is reflected in the relationships with $\mathrm{CMI}$ and topographic ruggedness. When examining maps of predictor variables, variability in maximum temperature in September identifies the prairie region, while variability in minimum November temperature likely identifies portions of the boreal region where Pintails occurred in higher abundances. While the importance of amount of shoreline may reflect a biological relationship describing Pintails dependence on water, it appears that most of the variables simply reflect a spatial rather than mechanistic relationship. This finding is not surprising because observed Pintails likely represent at least two populations: those inhabiting the prairies and those that fly directly to the arctic (Miller et al. 2005, Mattsson et al. 2012). Modelling the two groups together may yield predictive environmental variables that are not mechanistically meaningful. 
Northern Shoveler - ground nesting dabbling

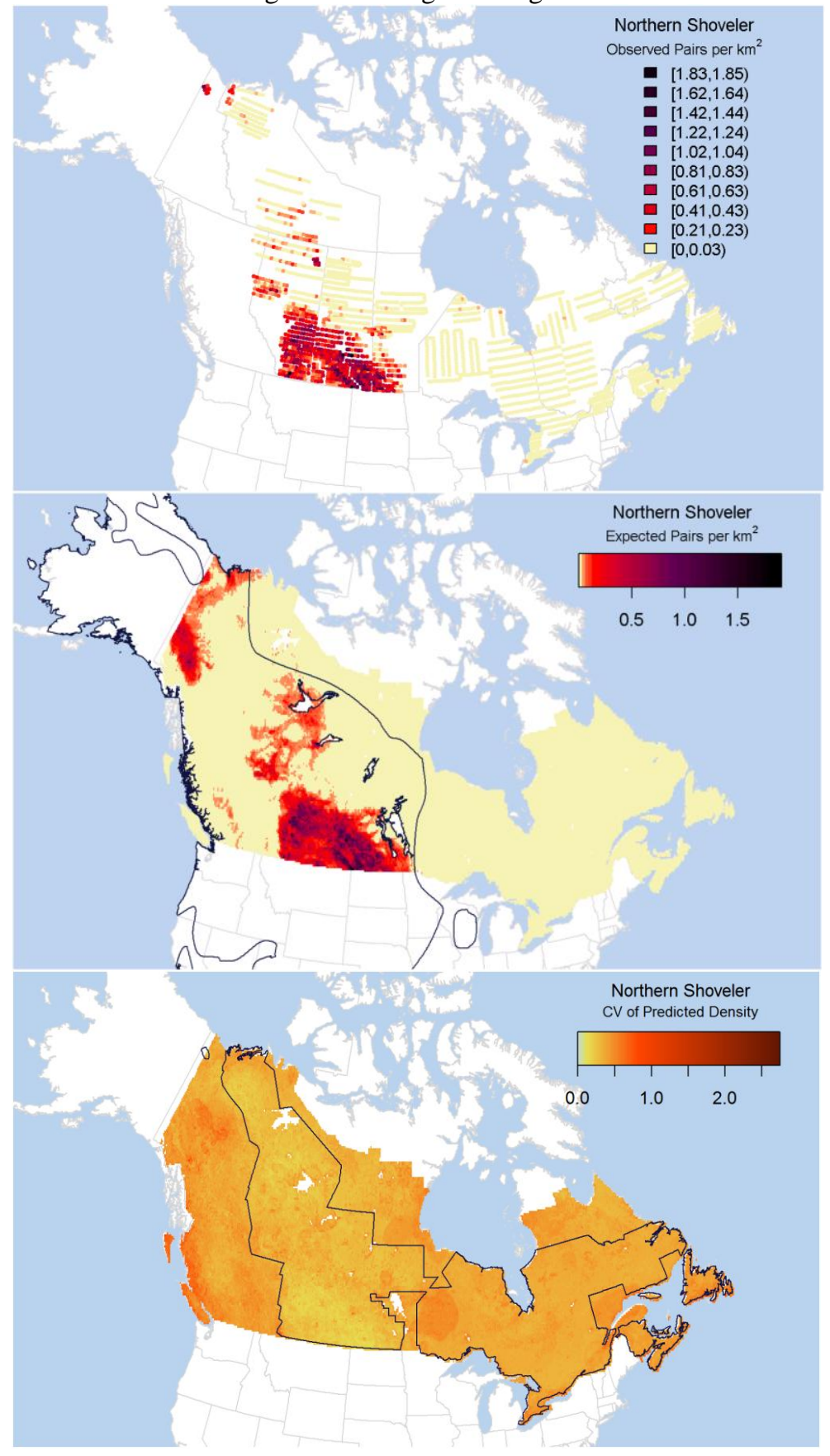

Our models predicted high densities of Shovelers in the prairies, along with the Yukon and among some of the parkland areas around the Slave Lakes, which is generally consistent with published ranges (Dubowy 1996, BirdLife International and NatureServe 2012). Johnsgard (2010), however, states that it is an uncommon breeder in Alaska, suggesting that our predicted northern abundances are higher than traditionally recognized. Our model 
predicted only very low abundances of Shovelers within Ontario and Québec, despite observations within Ontario in the raw data, and records of breeding Shoveler in the Breeding Bird Atlases of Ontario and Québec (Bird Studies Canada et al. 2009, Regroupement QuébecOiseaux et al. 2014).

$\begin{array}{lccc}\text { Variable } & \text { Mean \% } & \text { SD } & \text { Cumulative \% } \\ \text { Mean Climate Moisture Index } & 22.91 & 3.46 & 22.91 \\ \text { \% Cropland } & 19.06 & 3.43 & 41.97 \\ \text { Amount of Shoreline }\left(\mathrm{km}^{\mathrm{k}} \mathrm{km}{ }^{2}\right) & 8.14 & 1.91 & 50.11 \\ \text { \% Open Water (HWL) } & 5.65 & 1.10 & 55.76 \\ \text { Density of Waterbodies (neighbourhood metric) } & 3.83 & 1.86 & 59.60 \\ \text { Topographic Ruggedness } & 3.74 & 0.48 & 63.33 \\ \text { Standard Deviation of Maximum Temperature in August } & 3.09 & 1.10 & 66.42 \\ \text { Precipitation Seasonality } & 2.15 & 1.00 & 68.57 \\ \text { Standard Deviation of Maximum Temperature in September } & 2.00 & 0.69 & 70.58 \\ \text { Amount of Streams (km/km²) } & 1.85 & 0.49 & 72.43 \\ \text { \% Wetland (HWL) } & 1.32 & 0.26 & 73.75 \\ \text { \% Cropland-woodland } & 1.24 & 0.26 & 74.99 \\ \text { Mean Shoreline Complexity (neighbourhood metric) } & 0.88 & 0.30 & 75.88 \\ \text { Standard Deviation of Maximum Temperature in January } & 0.85 & 0.29 & 76.72 \\ \text { Standard Deviation of Precipitation in October } & 0.79 & 0.32 & 77.51 \\ \text { Standard Deviation of Minimum Temperature in November } & 0.78 & 0.26 & 78.29 \\ \text { Standard Deviation of Precipitation in August } & 0.77 & 0.30 & 79.06 \\ \text { \% Deciduous Forest } & 0.74 & 0.22 & 79.80 \\ \text { Mean Gross Primary Productivity } & 0.70 & 0.29 & 80.51\end{array}$

Shoveler abundance was most closely associated with CMI and amount of cropland, followed by three hydrological variables: amount of shoreline; amount of open water; and water body density. As with other western dabblers, the former two variables may capture the high densities of the species in the prairie-parkland region. Shovelers prefer hayland and avoid nesting in cropland (Greenwood et al. 1995), a subtle distinction our coarse-scale models likely did not identify. Since they especially favour shallow, eutrophic wetlands with abundant floating animal and plant life (Johnsgard 2010), we might have expected a strong relationship with GPP. Instead, we found a strong relationship with hydrological variables, suggesting that GPP may not indicate wetland productivity as intended, and/or that this coarse-scale analysis identifies variables associated with largescale patterns in abundance but not reflecting fine-scale habitat selection. 
Bufflehead - cavity nesting diving

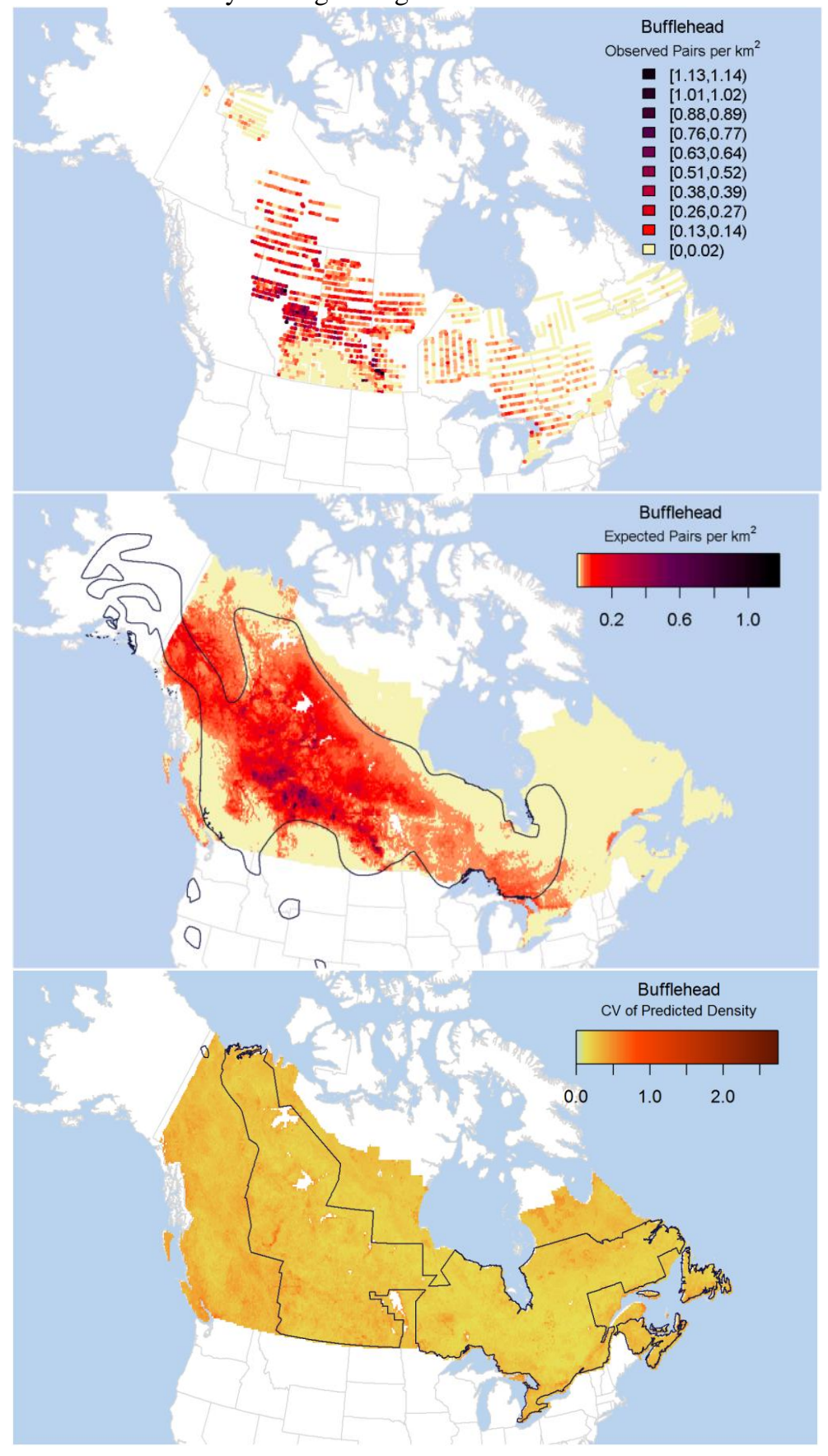

Compared to dabblers, the predicted distribution of Buffleheads was more homogenous across the study area, with a less well-defined core area. The highest densities were located in the Peace-Athabasca Parklands, with a few areas of high abundance in the southern aspen parkland. The species was nearly absent from the prairies, 
which is consistent with published ranges (Johnsgard 2010, BirdLife International and NatureServe 2012) and their dependence on trees for nesting.

$\begin{array}{lccc}\text { Variable } & \text { Mean \% } & \text { SD } & \text { Cumulative \% } \\ \text { Standard Deviation of Minimum Temperature in July } & 18.81 & 3.02 & 18.81 \\ \text { \% Deciduous Forest } & 9.04 & 1.28 & 27.85 \\ \text { Standard Deviation of Growing Season Length } & 5.40 & 0.91 & 33.26 \\ \text { Density of Waterbodies (neighbourhood metric) } & 4.62 & 1.14 & 37.88 \\ \text { Standard Deviation of Minimum Temperature in November } & 4.21 & 0.71 & 42.08 \\ \text { \% Open Water (HWL) } & 4.10 & 1.11 & 46.19 \\ \text { Amount of Shoreline (km/km²) } & 2.80 & 0.71 & 48.99 \\ \text { Standard Deviation of Minimum Temperature in December } & 2.36 & 0.53 & 51.34 \\ \text { \% Cropland-woodland } & 2.15 & 0.80 & 53.50 \\ \text { Standard Deviation of Maximum Temperature in November } & 1.77 & 0.80 & 55.27 \\ \text { Standard Deviation of Maximum Temperature in December } & 1.72 & 0.41 & 56.99 \\ \text { Standard Deviation of Minimum Temperature in June } & 1.56 & 0.74 & 58.55 \\ \text { Standard Deviation of Minimum Temperature in January } & 1.30 & 0.38 & 59.85 \\ \text { Standard Deviation of Minimum Temperature in October } & 1.26 & 0.57 & 61.11 \\ \text { Mean Climate Moisture Index } & 1.24 & 0.41 & 62.35 \\ \text { Mean Summer Maximum Temperature } & 1.19 & 0.32 & 63.54 \\ \text { Mean Shoreline Complexity (neighbourhood metric) } & 1.15 & 0.36 & 64.69 \\ \text { Standard Deviation of Maximum Temperature in October } & 1.14 & 0.63 & 65.83 \\ \text { Mean Gross Primary Productivity } & 1.13 & 0.23 & 66.96 \\ \text { Precipitation Seasonality } & 1.12 & 0.52 & 68.08 \\ \text { Standard Deviation of Maximum Temperature in September } & 1.11 & 0.46 & 69.19 \\ \text { Standard Deviation of Maximum Temperature in March } & 1.06 & 0.37 & 70.24 \\ \text { Mean Summer Precipitation } & 1.06 & 0.58 & 71.30 \\ \text { Mean Autumn Minimum Temperature } & 1.00 & 0.41 & 72.30 \\ \text { Standard Deviation of Maximum Temperature in January } & 1.00 & 0.32 & 73.30 \\ \text { Topographic Ruggedness } & 0.94 & 0.30 & 74.24 \\ \text { Standard Deviation of Maximum Temperature in February } & 0.93 & 0.30 & 75.17 \\ \text { Mean Growing Season Length } & 0.91 & 0.47 & 76.08 \\ \text { Annual Range in Temperature } & 0.83 & 0.26 & 76.91 \\ \text { Standard Deviation of Maximum Temperature in April } & 0.83 & 0.40 & 77.74 \\ \text { Standard Deviation of Minimum Temperature in March } & 0.80 & 0.24 & 78.54 \\ \text { Standard Deviation of Precipitation in June } & 0.79 & 0.48 & 79.33 \\ \text { \% Mixed Forest - Deciduous-dominated } & 0.78 & 0.28 & 80.11 \\ & & & \end{array}$

Bufflehead abundance was closely associated with variability in minimum July temperature, followed by amount of deciduous forest and variability in growing season length. Three of the seven most important variables were hydrological: water body density; amount of open water; and shore length. We suspect that the bioclimatic variables are associated with the large-scale spatial pattern of abundance, though the variability in growing season may reflect the species' more boreal distribution. The relationship with amount of deciduous forest is as expected for a cavity-nesting species "associated with temperate forests" (Johnsgard 2010). The top three hydrological variables identified were wetland density, stream length, and the amount of open water as measured by the high resolution HWL product. These relationships are consistent with the species' association with small ponds (Gauthier 1993) on riparian networks such as produced by beavers (Naiman et al. 1988). 
Goldeneye species - cavity nesting diving

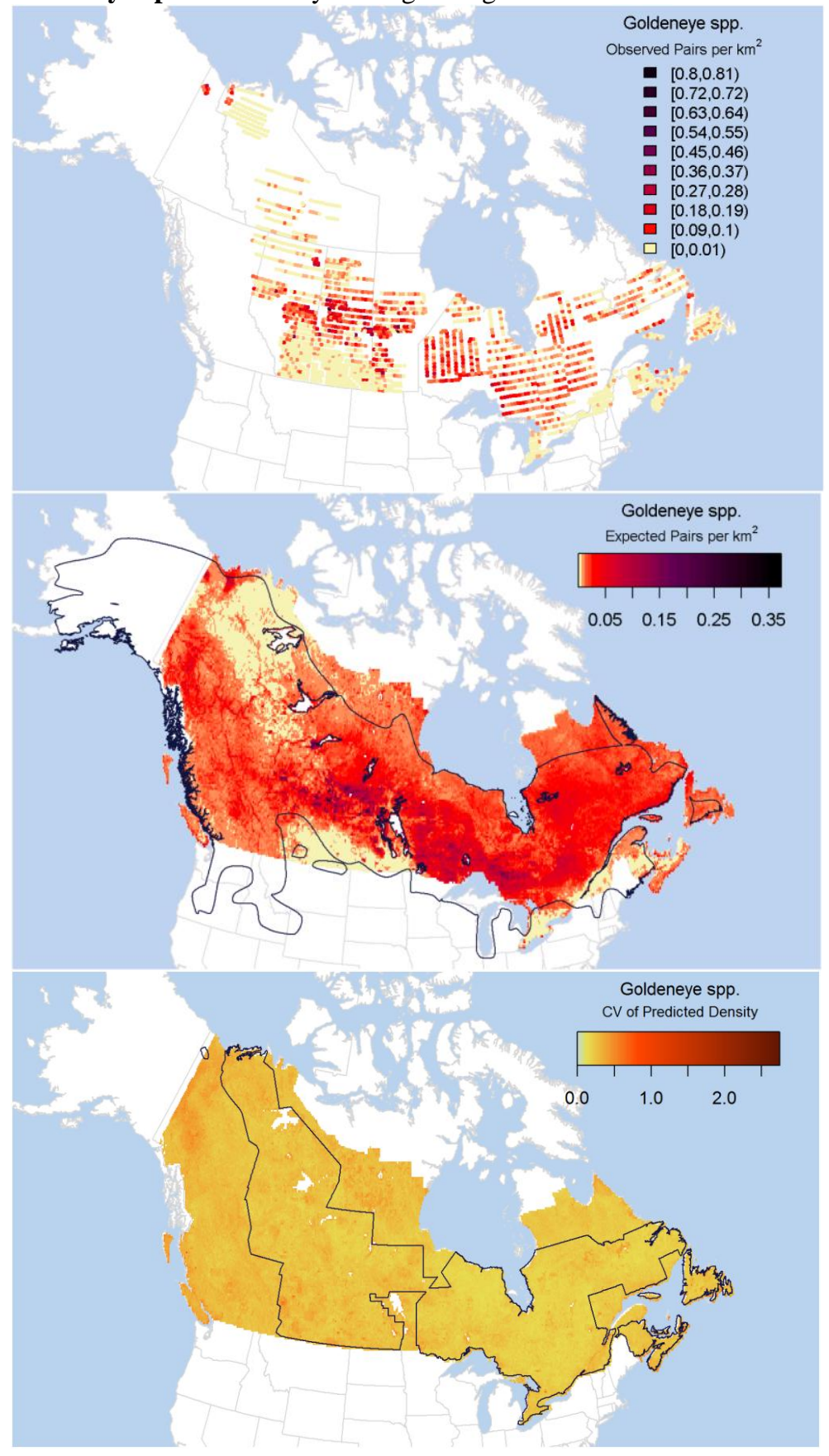

Our models predicted that goldeneyes live across much of our study area, with higher densities in the East and around the aspen parkland. Although our models grouped the Barrow's and Common Goldeneye species together, we might conclude that the majority of the observations were for Common Goldeneye, given the larger distribution of this species. Our predictions largely match range maps (BirdLife International and NatureServe 
2012), including absence from the southern lowlands, and are consistent with higher abundances in eastern provinces (Johnsgard 2010). As with the Bufflehead, goldeneye species are much less abundant in the prairies (Eadie et al. 1995), which is reflected in our predictions.

$\begin{array}{lccc}\text { Variable } & \text { Mean \% } & \text { SD } & \text { Cumulative \% } \\ \text { \% Open Water (HWL) } & 20.76 & 3.40 & 20.76 \\ \text { Precipitation Seasonality } & 7.75 & 2.26 & 28.51 \\ \text { Mean Summer Maximum Temperature } & 6.29 & 1.58 & 34.80 \\ \text { Standard Deviation of Minimum Temperature in July } & 3.09 & 0.74 & 37.89 \\ \text { Standard Deviation of Minimum Temperature in December } & 2.30 & 0.89 & 40.19 \\ \text { \% High Density Evergreen Forest } & 2.21 & 0.52 & 42.40 \\ \text { Topographic Ruggedness } & 2.01 & 1.02 & 44.41 \\ \text { Mean Waterbody Area (neighbourhood metric) } & 1.99 & 0.57 & 46.40 \\ \text { Standard Deviation of Minimum Temperature in June } & 1.99 & 0.39 & 48.39 \\ \text { Shannon's Diversity Index of Land Cover Types } & 1.95 & 0.57 & 50.33 \\ \text { Mean Gross Primary Productivity } & 1.91 & 0.68 & 52.24 \\ \text { \% Deciduous Forest } & 1.79 & 0.43 & 54.03 \\ \text { \% Mixed Forest - Evergreen-dominated } & 1.73 & 0.45 & 55.76 \\ \text { Amount of Shoreline (km/km²) } & 1.66 & 0.39 & 57.43 \\ \text { Standard Deviation of Minimum Temperature in August } & 1.66 & 0.55 & 59.08 \\ \text { Mean Winter Precipitation } & 1.65 & 0.68 & 60.73 \\ \text { Mean Autumn Minimum Temperature } & 1.58 & 0.82 & 62.31 \\ \text { Standard Deviation of Maximum Temperature in August } & 1.53 & 0.46 & 63.84 \\ \text { Mean Spring Minimum Temperature } & 1.50 & 0.47 & 65.35 \\ \text { \% Low Density Evergreen } & 1.34 & 0.53 & 66.69 \\ \text { Mean Growing Season Length } & 1.29 & 0.44 & 67.98 \\ \text { Mean Summer Minimum Temperature } & 1.21 & 0.38 & 69.20 \\ \text { Standard Deviation of Minimum Temperature in January } & 1.10 & 0.86 & 70.30 \\ \text { Standard Deviation of Growing Season Length } & 1.08 & 0.43 & 71.38 \\ \text { Density of Waterbodies (neighbourhood metric) } & 1.05 & 0.60 & 72.43 \\ \text { Mean Spring Maximum Temperature } & 1.03 & 0.49 & 73.46 \\ \text { Standard Deviation of Minimum Temperature in March } & 1.02 & 0.53 & 74.49 \\ \text { \% Mixed Forest - Deciduous-dominated } & 0.97 & 0.28 & 75.46 \\ \text { Standard Deviation of Minimum Temperature in November } & 0.94 & 0.44 & 76.40 \\ \text { Mean Shoreline Complexity (neighbourhood metric) } & 0.90 & 0.30 & 77.30 \\ \text { Standard Deviation of Precipitation in January } & 0.84 & 0.39 & 78.14 \\ \text { Mean Summer Precipitation } & 0.84 & 0.22 & 78.99 \\ \text { Standard Deviation of Precipitation in November } & 0.84 & 0.43 & 79.83 \\ \text { Standard Deviation of Minimum Temperature in October } & 0.83 & 0.36 & 80.66 \\ & & & \\ & & \end{array}$

Goldeneye abundance was most closely associated with amount of open water, followed by precipitation seasonality and the mean maximum July temperature. The amount of high density evergreen forest was ranked sixth most important, and the amount of coniferous forest was ranked twelfth. The very strong association with amount of open water may represent both a biological and spatial association. It is the only hydrological variable in the top seven, and likely captures the dependence of the species on water bodies for feeding. Goldeneyes also prefer water bodies with less shoreline vegetation (Eadie et al. 1995), which may be reflected in this open water variable. Area of water bodies was the eighth most important variable, and the goldeneye group represents one of the only species with this variable ranked within the top 10 variables. Goldeneyes tend to prefer smaller lakes 
over larger ones, but they also prefer lakes with a depth of at least $1 \mathrm{~m}$ (Eadie et al. 1995, 2000). Our water body area variable may be providing information about water depth, as we had intended. The roughly quadratic association with mean July temperature appears to be a spatial correspondence explaining the species' transcontinental distribution. The association with coniferous and deciduous forest further captures this transcontinental distribution, as well as the dependence of the species on trees for cavities, which is stronger for Common Goldeneyes than for Barrow's (Johnsgard 2010). 
Merganser species - cavity nesting diving

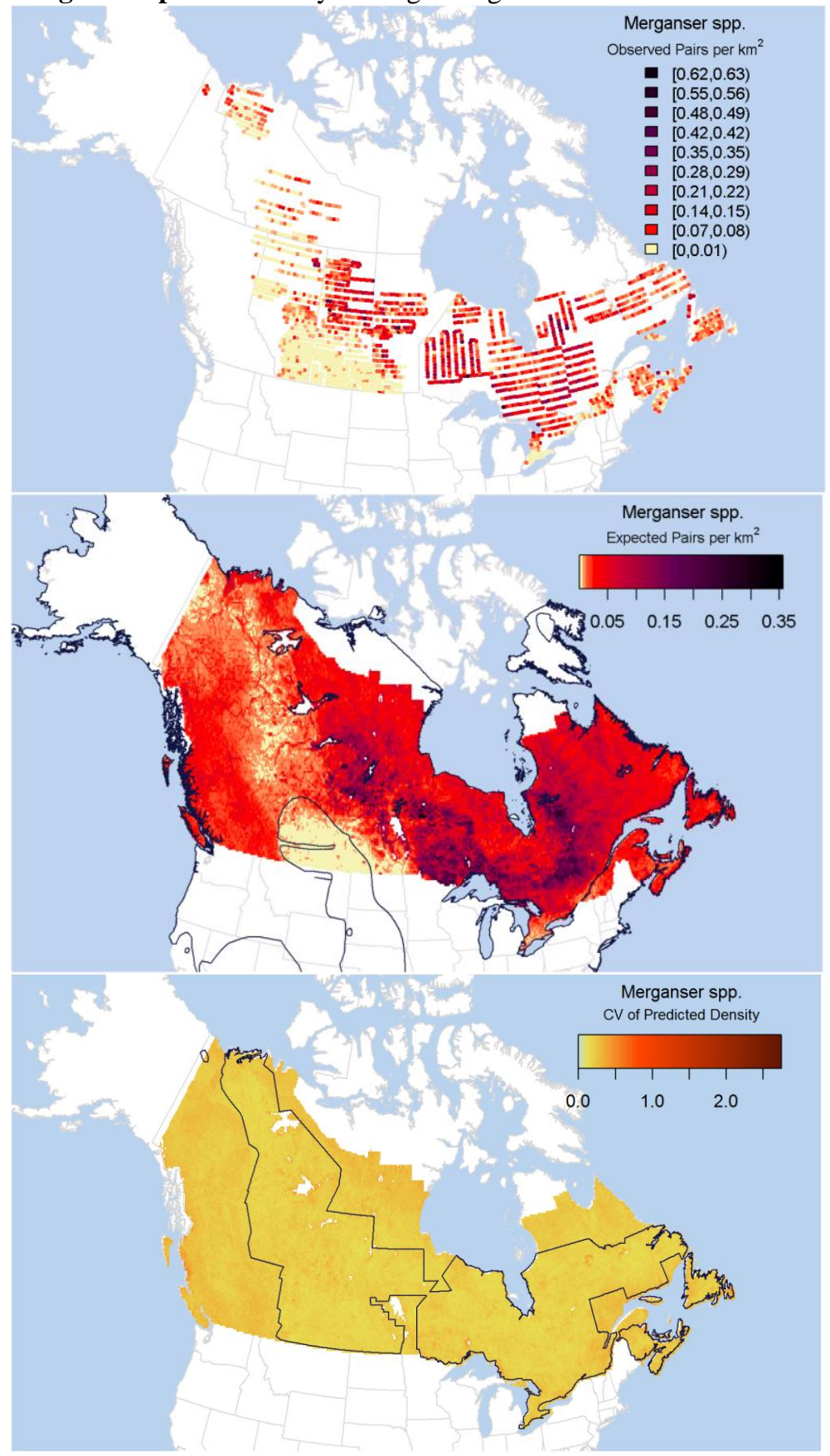

Our models predicted a very similar distribution for merganser species as it did for goldeneye species. Like the goldeneyes, this model grouped more than one species, but our predictions are largely consistent with the combined distribution of the three species included in the group (BirdLife International and NatureServe 2012). 


Variable
\% Open Water (HWL)
\% High Density Evergreen Forest
Standard Deviation of Minimum Temperature in June
Mean Waterbody Area (neighbourhood metric)
Amount of Shoreline (km/km²)
Density of Waterbodies (neighbourhood metric)
Standard Deviation of Maximum Temperature in November
Mean Gross Primary Productivity
Mean Shoreline Complexity (neighbourhood metric)
\% Wetland (HWL)
Mean Summer Maximum Temperature
\% Low Density Evergreen
\% Mixed Forest - Evergreen-dominated
Standard Deviation of Maximum Temperature in July
Standard Deviation of Minimum Temperature in August
Shannon's Diversity Index of Land Cover Types
Topographic Ruggedness
Standard Deviation of Maximum Temperature in February
Mean Summer Minimum Temperature
Standard Deviation of Precipitation in June
Amount of Streams (km/km²)
\% Mixed Forest - Deciduous-dominated
Standard Deviation of Precipitation in July
Standard Deviation of Maximum Temperature in June
\% Medium-density Evergreen Forest
Standard Deviation of Minimum Temperature in January
Mean Growing Season Length
Standard Deviation of Precipitation in April
Standard Deviation of Minimum Temperature in July
Standard Deviation of Maximum Temperature in April

$\begin{array}{ccc}\text { Mean \% } & \text { SD } & \text { Cumulative \% } \\ 21.44 & 2.24 & 21.44 \\ 10.60 & 1.22 & 32.04 \\ 5.60 & 0.98 & 37.65 \\ 4.48 & 1.46 & 42.13 \\ 3.10 & 0.50 & 45.23 \\ 3.01 & 0.85 & 48.24 \\ 2.85 & 0.46 & 51.09 \\ 2.12 & 0.66 & 53.21 \\ 2.08 & 0.46 & 55.29 \\ 1.98 & 0.72 & 57.27 \\ 1.90 & 0.54 & 59.16 \\ 1.80 & 0.53 & 60.96 \\ 1.65 & 0.27 & 62.61 \\ 1.48 & 0.22 & 64.09 \\ 1.42 & 0.44 & 65.51 \\ 1.36 & 0.29 & 66.87 \\ 1.25 & 0.21 & 68.13 \\ 1.15 & 0.26 & 69.28 \\ 1.09 & 0.46 & 70.37 \\ 1.05 & 0.23 & 71.43 \\ 1.04 & 0.38 & 72.47 \\ 1.01 & 0.22 & 73.47 \\ 0.98 & 0.37 & 74.46 \\ 0.94 & 0.32 & 75.40 \\ 0.93 & 0.31 & 76.33 \\ 0.93 & 0.41 & 77.26 \\ 0.90 & 0.54 & 78.16 \\ 0.90 & 0.33 & 79.06 \\ 0.86 & 0.31 & 79.92 \\ 0.80 & 0.22 & 80.72 \\ & & \end{array}$

Merganser abundance was strongly associated with amount of open water, followed by amount of high density evergreen forest, variability in minimum June temperature, area of water bodies in the surrounding area, amount of shoreline, and water body density. Relationships with forest and the climatic variable likely originate from the transcontinental distribution of this species group. The relationship with evergreen forest may capture the association of the Common Merganser with forested landscapes, but the more flexible, facultative groundnesting Red-breasted Merganser is somewhat less associated with forests (Johnsgard 2010). This species group was closely associated with more water variables than most other species. In addition to the above four hydrological variables, shoreline complexity and amount of wetland were the ninth and tenth most important variables. This pattern may reflect the species' strong dependence on relatively deeper, more oligotrophic, open and clear water for foraging for fish (Mallory and Metz 1999, Johnsgard 2010). 
Scoter species - ground nesting diving

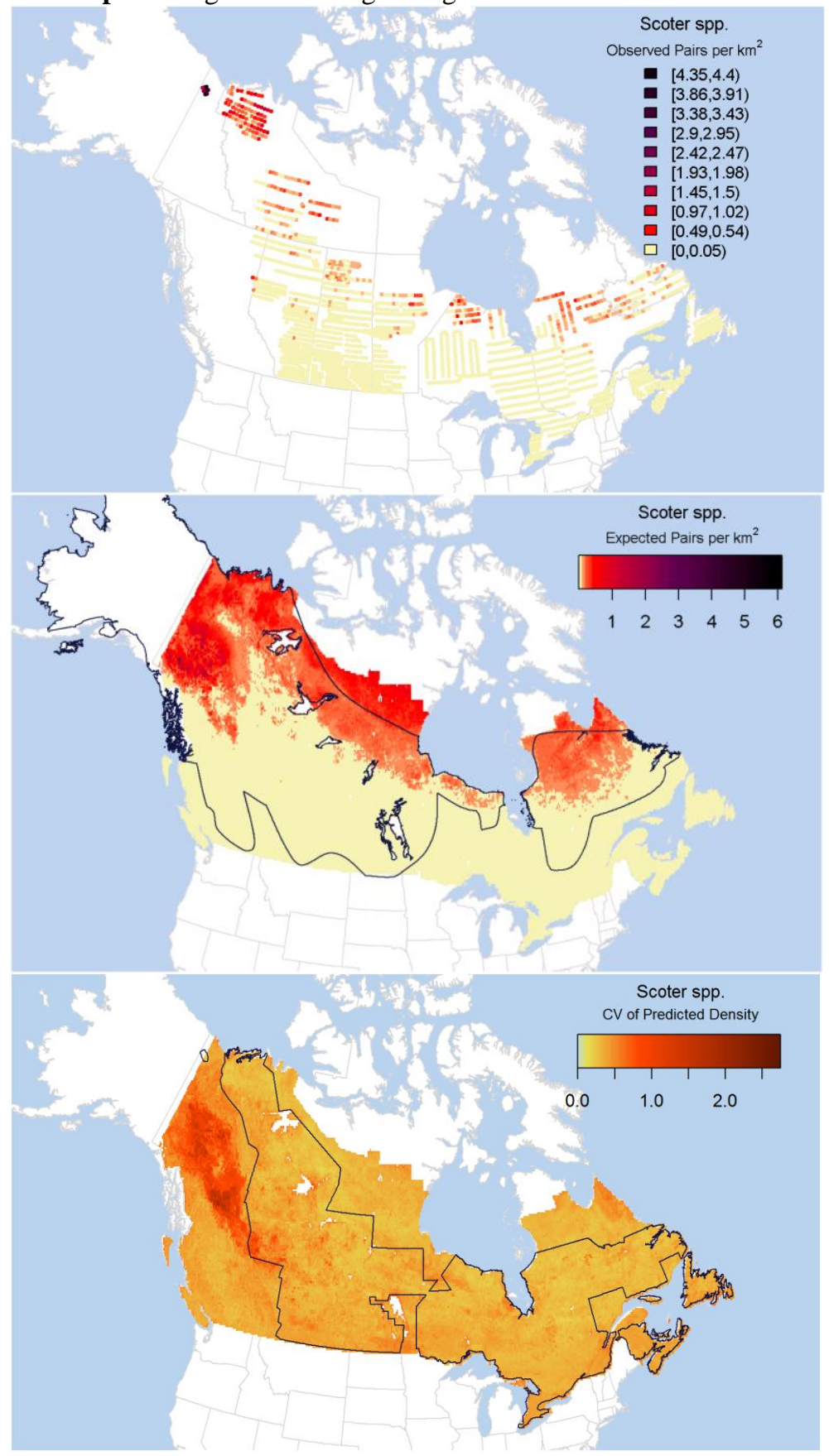

Our models predicted the highest abundances of scoters along the northern limits of our study area and in much of the Yukon. Although the survey, and therefore our model, does not distinguish among the scoter species, published range maps suggest that our predictions likely represent Surf and White-winged Scoter, since these species live primarily in the surveyed western boreal forest (Johnsgard 2010, BirdLife International and 
NatureServe 2012), with highest population densities in the northwestern boreal (Bellrose 1980). This is somewhat consistent with our prediction maps, but our models predictions extended well north of published ranges, likely due to extrapolation error (see Discussion).

$\begin{array}{lccc}\text { Variable } & \text { Mean \% } & \text { SD } & \text { Cumulative \% } \\ \text { Mean Autumn Maximum Temperature } & 36.89 & 7.82 & 36.89 \\ \text { Mean Winter Minimum Temperature } & 16.02 & 5.22 & 52.91 \\ \text { Standard Deviation of Minimum Temperature in October } & 7.17 & 3.67 & 60.08 \\ \text { Mean Growing Season Length } & 6.56 & 4.77 & 66.64 \\ \text { Standard Deviation of Minimum Temperature in April } & 4.54 & 2.57 & 71.19 \\ \text { Mean Spring Precipitation } & 3.34 & 1.84 & 74.53 \\ \text { Standard Deviation of Minimum Temperature in September } & 2.69 & 1.20 & 77.22 \\ \text { Mean Gross Primary Productivity } & 2.52 & 2.74 & 79.74 \\ \text { Temperature Seasonality } & 2.37 & 1.00 & 82.11\end{array}$

Scoter abundance was strongly related to mean maximum autumn temperature, followed by mean minimum winter temperature, variability in minimum October temperature, and the mean growing season length. Moreso than any other species, the top variables for scoters were climatic in nature, many of which have a strong NorthSouth gradient. This gradient explains the overprediction north of the treeline. Scoters are generally associated with freshwater lakes and ponds in boreal forests (Savard et al. 1998) and avoid tundra (Haszard and Clark 2007, Johnsgard 2010). However, since the raw survey data did not include areas of tundra to calibrate the models, scoter density appears to be increasing with latitude, which is captured by environmental variables with NorthSouth gradients, leading to overprediction in northern areas beyond the survey limits and treeline. 
Canvasback - over-water nesting diving

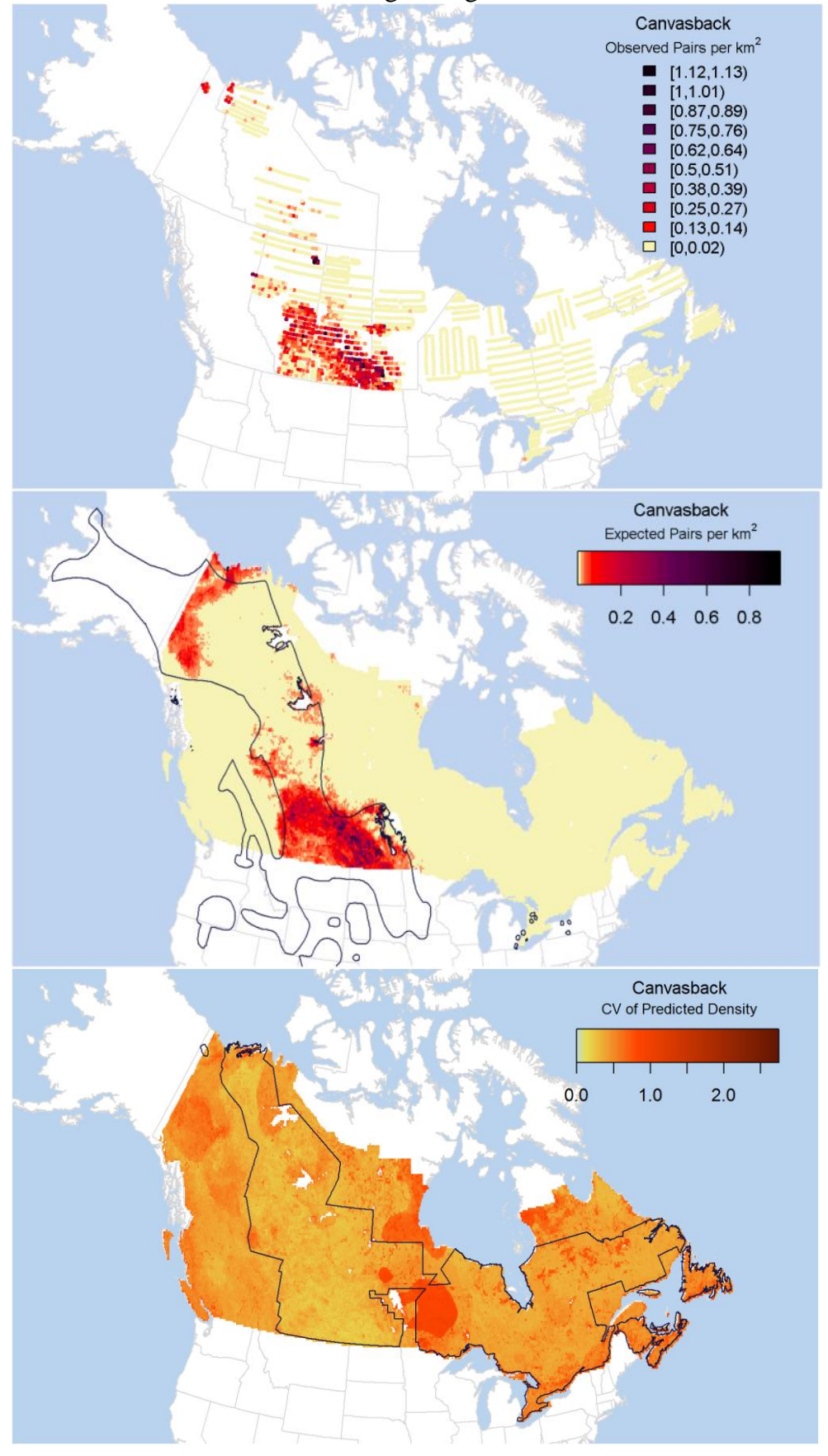

Our models predicted high densities of Canvasback in the aspen parkland, as well as some areas of higher abundance in the Yukon, which is largely consistent with published accounts of their distribution (Mowbray 2002) and range limits (Johnsgard 2010, BirdLife International and NatureServe 2012), however the 
NatureServe range excludes the MacKenzie Delta, in contrast with relatively high observed and predicted abundances in the region.

$\begin{array}{lccc}\text { Variable } & \text { Mean \% } & \text { SD } & \text { Cumulative \% } \\ \text { \% Open Water (HWL) } & 10.87 & 1.50 & 10.87 \\ \text { Amount of Shoreline (km/km²) } & 10.12 & 1.87 & 20.99 \\ \text { \% Cropland } & 9.76 & 2.18 & 30.75 \\ \text { \% Deciduous Forest } & 5.20 & 1.17 & 35.95 \\ \text { Precipitation Seasonality } & 4.11 & 0.89 & 40.06 \\ \text { \% Cropland-woodland } & 3.97 & 0.78 & 44.03 \\ \text { Standard Deviation of Maximum Temperature in August } & 3.23 & 1.21 & 47.26 \\ \text { Topographic Ruggedness } & 3.17 & 0.66 & 50.43 \\ \text { Amount of Streams (km/km²) } & 3.15 & 0.89 & 53.57 \\ \text { Density of Waterbodies (neighbourhood metric) } & 2.83 & 0.90 & 56.41 \\ \text { Mean Climate Moisture Index } & 2.75 & 1.52 & 59.16 \\ \text { Mean Spring Maximum Temperature } & 1.54 & 0.94 & 60.70 \\ \text { Mean Summer Precipitation } & 1.51 & 0.90 & 62.21 \\ \text { Mean Winter Maximum Temperature } & 1.46 & 0.64 & 63.68 \\ \text { Standard Deviation of Precipitation in August } & 1.46 & 0.60 & 65.13 \\ \text { Standard Deviation of Maximum Temperature in September } & 1.42 & 0.49 & 66.55 \\ \text { Standard Deviation of Minimum Temperature in November } & 1.35 & 0.78 & 67.90 \\ \text { Standard Deviation of Precipitation in November } & 1.31 & 0.52 & 69.21 \\ \text { Mean Winter Precipitation } & 1.09 & 0.18 & 70.31 \\ \text { Standard Deviation of Minimum Temperature in October } & 1.07 & 0.53 & 71.38 \\ \text { \% Wetland (HWL) } & 1.01 & 0.38 & 72.39 \\ \text { Standard Deviation of Minimum Temperature in June } & 0.94 & 0.48 & 73.33 \\ \text { \% Mixed Forest - Deciduous-dominated } & 0.93 & 0.59 & 74.26 \\ \text { Standard Deviation of Maximum Temperature in March } & 0.90 & 0.35 & 75.16 \\ \text { Standard Deviation of Precipitation in July } & 0.85 & 0.41 & 76.01 \\ \text { Standard Deviation of Precipitation in October } & 0.85 & 0.58 & 76.86 \\ \text { Standard Deviation of Maximum Temperature in February } & 0.81 & 0.32 & 77.67 \\ \text { Mean Autumn Precipitation } & 0.80 & 0.37 & 78.47 \\ \text { Shannon's Diversity Index of Land Cover Types } & 0.79 & 0.30 & 79.26 \\ \text { Mean Winter Minimum Temperature } & 0.75 & 0.52 & 80.01\end{array}$

The most important variables in predicting Canvasback abundance were the amount of open water, the amount of shoreline, and the amount of cropland, followed by the amount of deciduous forest. The first two variables capture the dependence of the species on water, and may reflect the Canvasback's need for relatively large, open bodies of water for nesting, landing, and takeoff (Johnsgard 2010). While Johnsgard (2010) states that Canvasbacks prefer shallow prairie marshes, Mowbray (2002) and our work suggest a closer dependence on lakes and deeper ponds and marshes. The association with cropland and deciduous forest likely reflects the high abundance in the aspen parkland (Mowbray 2002). 
Redhead - over-water nesting diving

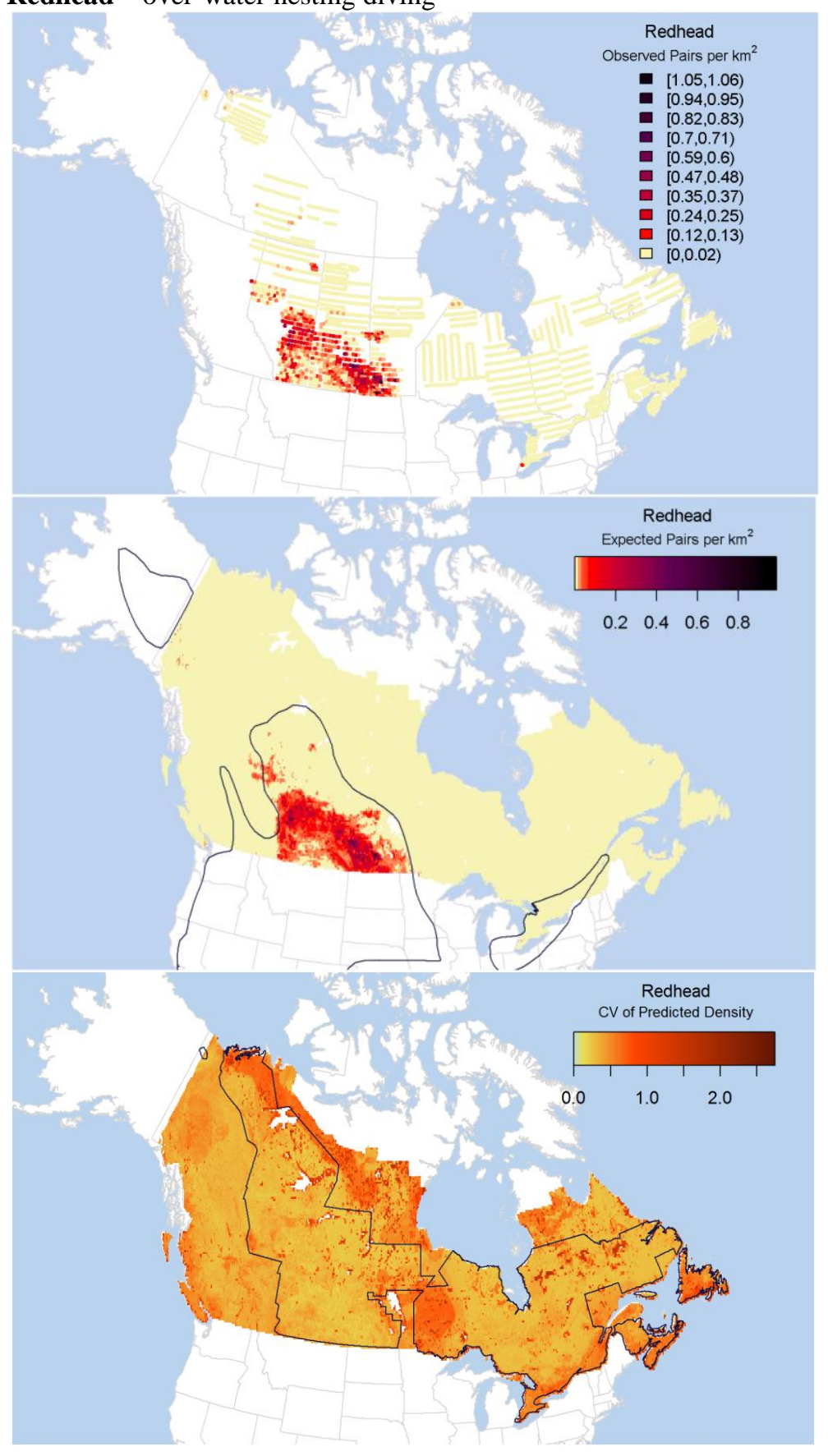

Our models predicted high densities of Redheads in the aspen parkland forest, which is largely consistent with published range maps (Johnsgard 2010, BirdLife International and NatureServe 2012). 


$\begin{array}{lccc}\text { Variable } & \text { Mean \% } & \text { SD } & \text { Cumulative \% } \\ \text { \% Cropland } & 12.23 & 1.61 & 12.23 \\ \text { Amount of Shoreline }\left(\mathrm{km} / \mathrm{km}^{2}\right) & 11.47 & 2.42 & 23.70 \\ \text { \% Open Water (HWL) } & 8.67 & 1.40 & 32.37 \\ \text { Density of Waterbodies (neighbourhood metric) } & 6.41 & 2.05 & 38.78 \\ \text { \% Cropland-woodland } & 5.13 & 0.92 & 43.91 \\ \text { Precipitation Seasonality } & 3.52 & 0.80 & 47.43 \\ \text { Topographic Ruggedness } & 3.10 & 0.95 & 50.53 \\ \text { \% Deciduous Forest } & 2.89 & 1.06 & 53.42 \\ \text { Amount of Streams (km/km²) } & 2.53 & 0.66 & 55.95 \\ \text { Mean Summer Precipitation } & 2.44 & 1.02 & 58.39 \\ \text { Standard Deviation of Precipitation in August } & 1.86 & 0.68 & 60.25 \\ \text { Standard Deviation of Maximum Temperature in May } & 1.69 & 0.62 & 61.94 \\ \text { Standard Deviation of Precipitation in September } & 1.61 & 1.43 & 63.55 \\ \text { \% Low Density Evergreen } & 1.49 & 1.30 & 65.05 \\ \text { Mean Gross Primary Productivity } & 1.41 & 0.77 & 66.46 \\ \text { Mean Precipitation in the Wettest Month } & 1.41 & 0.67 & 67.86 \\ \text { Shannon's Diversity Index of Land Cover Types } & 1.34 & 0.73 & 69.20 \\ \text { Standard Deviation of Maximum Temperature in August } & 1.31 & 0.49 & 70.51 \\ \text { Standard Deviation of Precipitation in December } & 1.20 & 0.85 & 71.71 \\ \text { \% Wetland (HWL) } & 1.14 & 0.50 & 72.85 \\ \text { Standard Deviation of Precipitation in November } & 1.12 & 0.46 & 73.97 \\ \text { Mean Climate Moisture Index } & 1.10 & 0.56 & 75.07 \\ \text { Mean Spring Maximum Temperature } & 1.04 & 0.49 & 76.10 \\ \text { Standard Deviation of Maximum Temperature in November } & 1.00 & 0.59 & 77.10 \\ \text { Standard Deviation of Minimum Temperature in June } & 0.87 & 0.46 & 77.97 \\ \text { Standard Deviation of Maximum Temperature in September } & 0.81 & 0.25 & 78.79 \\ \text { Standard Deviation of Maximum Temperature in January } & 0.75 & 0.46 & 79.53 \\ \text { Standard Deviation of Precipitation in June } & 0.73 & 0.28 & 80.26\end{array}$

The variables most closely associated with Redhead abundance were similar to those for the Canvasback. Amount of cropland was most important, followed by amount of shore line, amount of open water, water body density, and amount of cropland-woodland. The first four describe the large-scale pattern of association with the prairie-parkland region as well as the association of the species with water. The association with croplandwoodland likely captures the high abundances in the aspen parkland. Like Canvasback, Redheads prefer deeper, more open water bodies (Woodin and Michot 2002), and they are more abundant in the parklands, despite a reported association with nonforested wetlands (Johnsgard 2010). 
Ring-necked Duck - over-water nesting diving

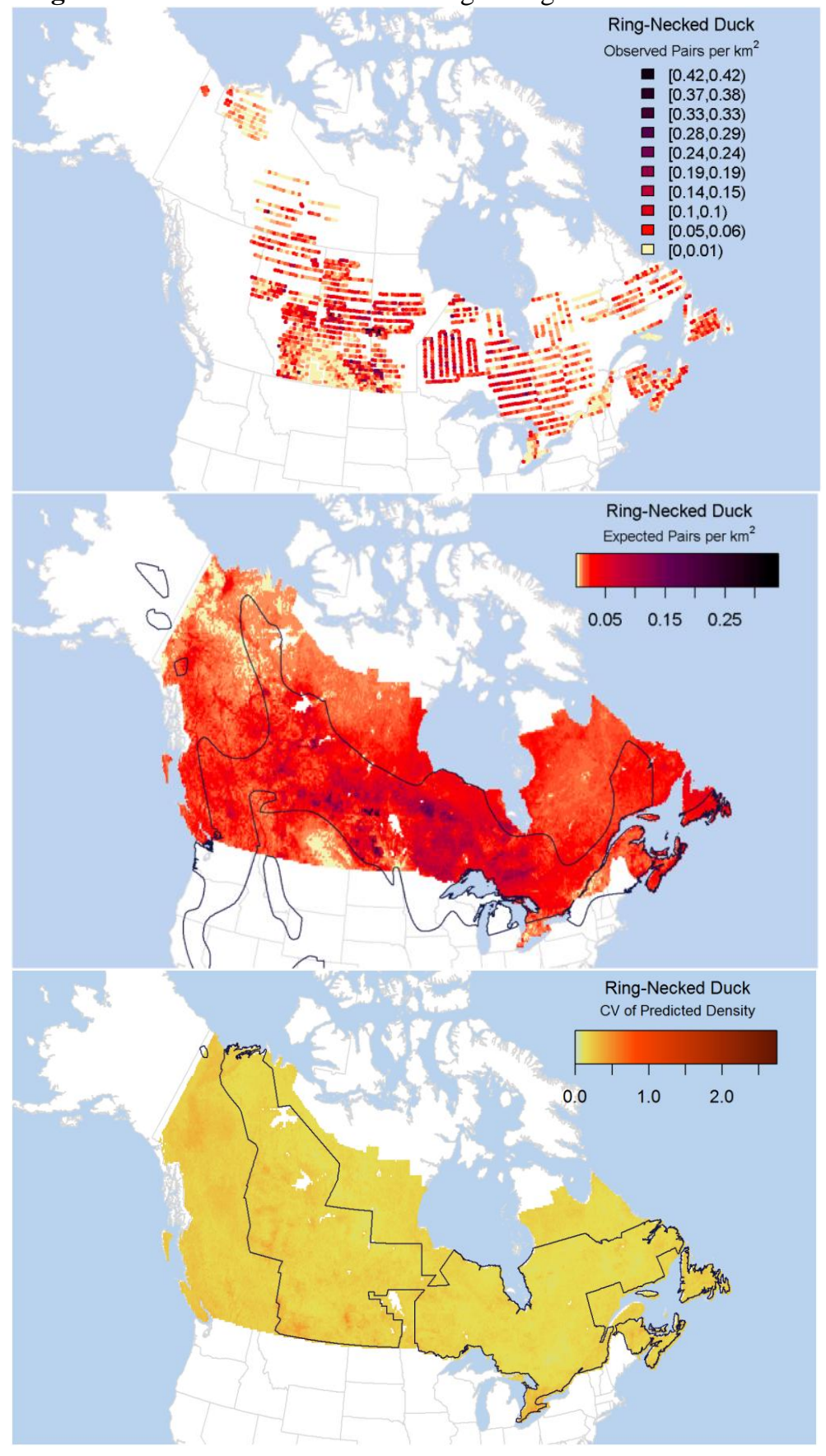

Our models predicted an extensive range of relatively homogenous abundance for Ring-necked Ducks. Slightly higher abundances were predicted within the published breeding range (BirdLife International and NatureServe 2012), but our models also predicted relatively high abundances well outside the documented range limits. Since 
raw observations of the species also indicate relatively high abundances outside the documented range, our modeled predictions may be more correct than current range maps in this case.

\begin{tabular}{|c|c|c|c|}
\hline Variable & Mean \% & SD & Cumulative $\%$ \\
\hline$\%$ Deciduous Forest & 7.37 & 1.33 & 7.37 \\
\hline \% Open Water (HWL) & 6.39 & 0.59 & 13.76 \\
\hline Amount of Shoreline $\left(\mathrm{km} / \mathrm{km}^{2}\right)$ & 4.51 & 0.94 & 18.28 \\
\hline Mean Gross Primary Productivity & 4.22 & 0.54 & 22.50 \\
\hline Standard Deviation of Minimum Temperature in June & 3.71 & 0.71 & 26.21 \\
\hline Density of Waterbodies (neighbourhood metric) & 3.18 & 0.45 & 29.39 \\
\hline Mean Summer Maximum Temperature & 2.88 & 0.78 & 32.27 \\
\hline Standard Deviation of Maximum Temperature in April & 2.76 & 0.66 & 35.03 \\
\hline Standard Deviation of Growing Season Length & 2.72 & 0.68 & 37.75 \\
\hline Standard Deviation of Precipitation in June & 2.28 & 0.47 & 40.03 \\
\hline Mean Winter Precipitation & 2.23 & 0.95 & 42.26 \\
\hline \% Mixed Forest - Evergreen-dominated & 2.00 & 0.43 & 44.26 \\
\hline Standard Deviation of Precipitation in November & 1.83 & 0.27 & 46.09 \\
\hline Topographic Ruggedness & 1.78 & 0.39 & 47.87 \\
\hline Standard Deviation of Minimum Temperature in December & 1.76 & 0.52 & 49.63 \\
\hline \% Mixed Forest - Deciduous-dominated & 1.73 & 0.28 & 51.35 \\
\hline Amount of Streams $\left(\mathrm{km} / \mathrm{km}^{2}\right)$ & 1.62 & 0.23 & 52.98 \\
\hline$\%$ Wetland (HWL) & 1.62 & 0.38 & 54.59 \\
\hline Standard Deviation of Precipitation in August & 1.56 & 0.35 & 56.15 \\
\hline Mean Summer Minimum Temperature & 1.55 & 0.36 & 57.70 \\
\hline Standard Deviation of Precipitation in January & 1.54 & 0.39 & 59.23 \\
\hline Standard Deviation of Minimum Temperature in September & 1.48 & 0.34 & 60.72 \\
\hline Standard Deviation of Precipitation in December & 1.46 & 0.41 & 62.18 \\
\hline Standard Deviation of Precipitation in July & 1.33 & 0.29 & 63.51 \\
\hline Standard Deviation of Maximum Temperature in November & 1.26 & 0.31 & 64.77 \\
\hline \% Medium-density Evergreen Forest & 1.25 & 0.29 & 66.01 \\
\hline Standard Deviation of Maximum Temperature in June & 1.22 & 0.22 & 67.23 \\
\hline Standard Deviation of Maximum Temperature in August & 1.18 & 0.44 & 68.41 \\
\hline Standard Deviation of Minimum Temperature in July & 1.17 & 0.26 & 69.58 \\
\hline \% Low Density Evergreen & 1.09 & 0.41 & 70.66 \\
\hline Standard Deviation of Maximum Temperature in September & 1.01 & 0.38 & 71.67 \\
\hline Shannon's Diversity Index of Land Cover Types & 1.00 & 0.23 & 72.67 \\
\hline Precipitation Seasonality & 0.98 & 0.30 & 73.65 \\
\hline Standard Deviation of Minimum Temperature in October & 0.96 & 0.19 & 74.61 \\
\hline$\%$ High Density Evergreen Forest & 0.92 & 0.25 & 75.53 \\
\hline Standard Deviation of Maximum Temperature in July & 0.91 & 0.25 & 76.43 \\
\hline Mean Climate Moisture Index & 0.90 & 0.27 & 77.33 \\
\hline Standard Deviation of Minimum Temperature in August & 0.90 & 0.12 & 78.23 \\
\hline Standard Deviation of Precipitation in September & 0.84 & 0.21 & 79.07 \\
\hline Standard Deviation of Minimum Temperature in May & 0.81 & 0.18 & 79.89 \\
\hline Mean Summer Precipitation & 0.81 & 0.23 & 80.70 \\
\hline
\end{tabular}

Ring-necked Duck abundance was associated with the amounts of deciduous forest, open water, and shoreline, as well as GPP, variability in minimum June temperature, and water body density. Given the relatively 
homogenous distribution, it is difficult to identify clear spatial associations with environmental variables by examining predictor variable maps, except perhaps the variability in minimum June temperature, which may be associated with relatively higher abundances in the middle of the species' range. Ring-necked Ducks nest in shallow marshes, swamps, and bogs, but especially favour bogs (Hohman and Eberhardt 1998, Johnsgard 2010). Our wetland classification did not differentiate between bogs and other wetlands, so it is possible that variables such as deciduous forest, a hydrological variable, GPP, or interactions among these variables acted as surrogates for bog wetlands. 
Ruddy Duck - over-water nesting diving

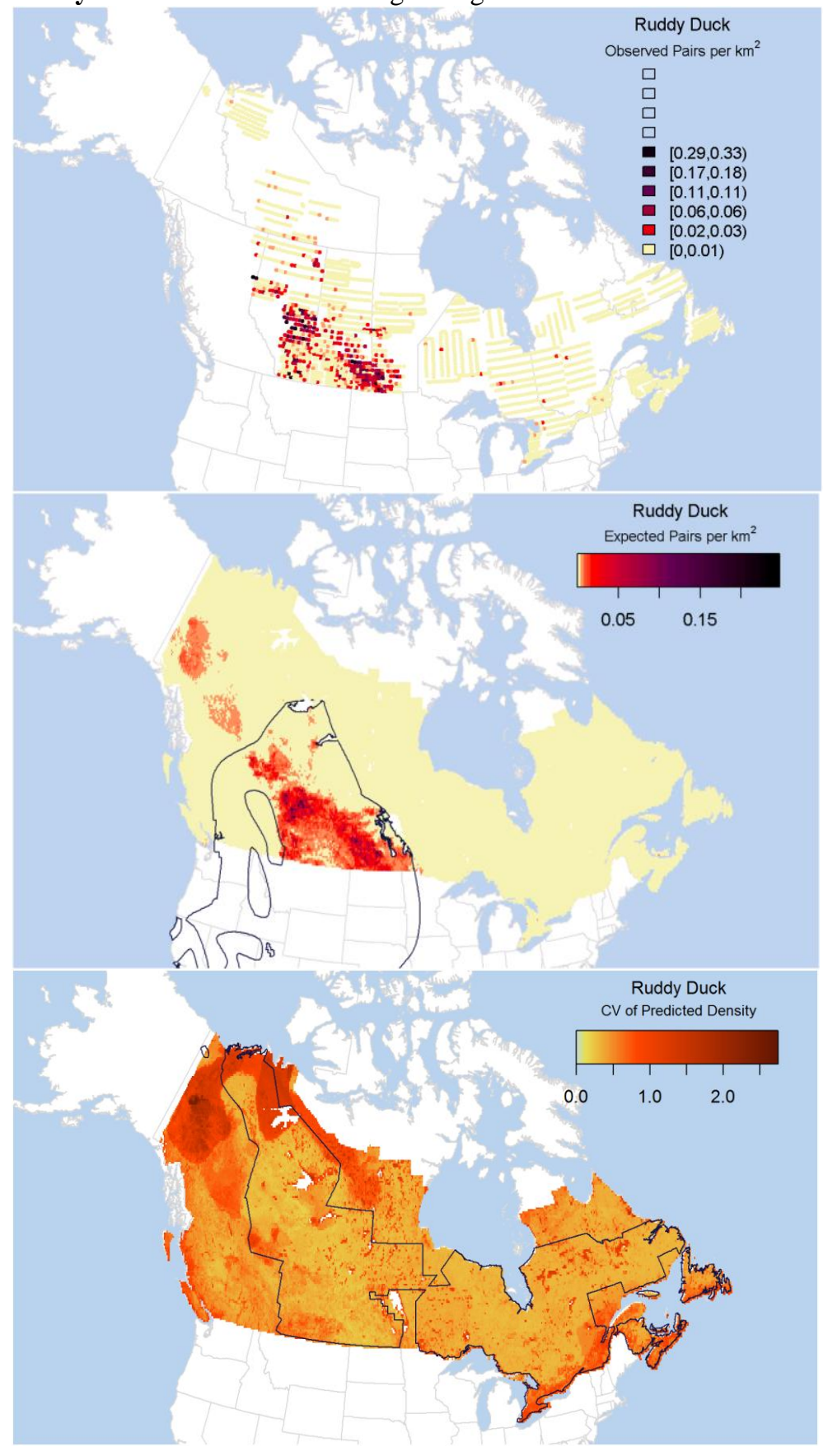

The Ruddy Duck had the lowest predicted abundance of all species we studied. Its highest predicted densities occurred in the prairie-parkland region, which is mostly consistent with Johnsgard (2010) and Brua (2002).

However, published ranges extend to unsurveyed areas of British Columbia where our models predict the species to be effectively absent. Our model predicted only very low abundances of Ruddy Ducks within Ontario and 
Québec, despite observations from the WBPHS, and the Breeding Bird Atlases of Ontario and Québec (Bird Studies Canada et al. 2009, Regroupement QuébecOiseaux et al. 2014).

$\begin{array}{lccc}\text { Variable } & \text { Mean \% } & \text { SD } & \text { Cumulative \% } \\ \text { \% Open Water (HWL) } & 10.19 & 2.96 & 10.19 \\ \text { \% Cropland-woodland } & 7.12 & 1.51 & 17.32 \\ \text { Density of Waterbodies (neighbourhood metric) } & 4.69 & 1.82 & 22.00 \\ \text { \% Cropland } & 4.67 & 1.17 & 26.67 \\ \text { Standard Deviation of Maximum Temperature in December } & 4.65 & 3.12 & 31.32 \\ \text { Amount of Shoreline (km/km²) } & 3.93 & 1.72 & 35.25 \\ \text { Precipitation Seasonality } & 3.45 & 1.15 & 38.70 \\ \text { Standard Deviation of Precipitation in May } & 3.31 & 2.59 & 42.01 \\ \text { Standard Deviation of Maximum Temperature in November } & 3.26 & 2.01 & 45.27 \\ \text { Standard Deviation of Growing Season Length } & 3.23 & 1.53 & 48.50 \\ \text { \% Deciduous Forest } & 2.27 & 0.85 & 50.77 \\ \text { \% Wetland (HWL) } & 2.11 & 0.97 & 52.88 \\ \text { Standard Deviation of Maximum Temperature in January } & 1.92 & 1.19 & 54.80 \\ \text { Standard Deviation of Maximum Temperature in February } & 1.90 & 1.29 & 56.70 \\ \text { Mean Climate Moisture Index } & 1.88 & 0.74 & 58.58 \\ \text { Amount of Streams (km/km²) } & 1.85 & 0.79 & 60.43 \\ \text { Shannon's Diversity Index of Land Cover Types } & 1.62 & 1.19 & 62.06 \\ \text { Topographic Ruggedness } & 1.48 & 0.61 & 63.54 \\ \text { Standard Deviation of Maximum Temperature in May } & 1.48 & 0.57 & 65.02 \\ \text { Standard Deviation of Precipitation in June } & 1.41 & 0.90 & 66.43 \\ \text { \% High Density Evergreen Forest } & 1.34 & 1.40 & 67.77 \\ \text { Standard Deviation of Maximum Temperature in September } & 1.30 & 0.59 & 69.07 \\ \text { Standard Deviation of Minimum Temperature in July } & 1.28 & 0.57 & 70.35 \\ \text { Standard Deviation of Minimum Temperature in June } & 1.28 & 0.41 & 71.63 \\ \text { Mean Precipitation in the Wettest Month } & 1.23 & 0.79 & 72.86 \\ \text { Standard Deviation of Minimum Temperature in October } & 1.23 & 0.99 & 74.09 \\ \text { Standard Deviation of Precipitation in April } & 1.13 & 0.46 & 75.22 \\ \text { Standard Deviation of Precipitation in September } & 1.11 & 0.66 & 76.34 \\ \text { Mean Gross Primary Productivity } & 1.03 & 0.50 & 77.37 \\ \text { Mean Summer Precipitation } & 1.00 & 0.52 & 78.37 \\ \text { \% Mixed Forest - Deciduous-dominated } & 0.99 & 0.70 & 79.36 \\ \text { Standard Deviation of Minimum Temperature in December } & 0.94 & 0.58 & 80.30\end{array}$

Ruddy Duck abundance was related to amounts of open water, cropland-woodland, cropland, and to water body density. The landcover covariates appear to identify the prairie-parkland region where the species occurs in greatest abundance. A relationship with water body density may reflect an association of this species with potholes, while a relationship with amount of open water may relate to the species' preferences for permanent and semi-permanent wetlands rather than shallow, seasonal ones (Brua 2002, Johnsgard 2010). 
Scaup species - over-water nesting diving

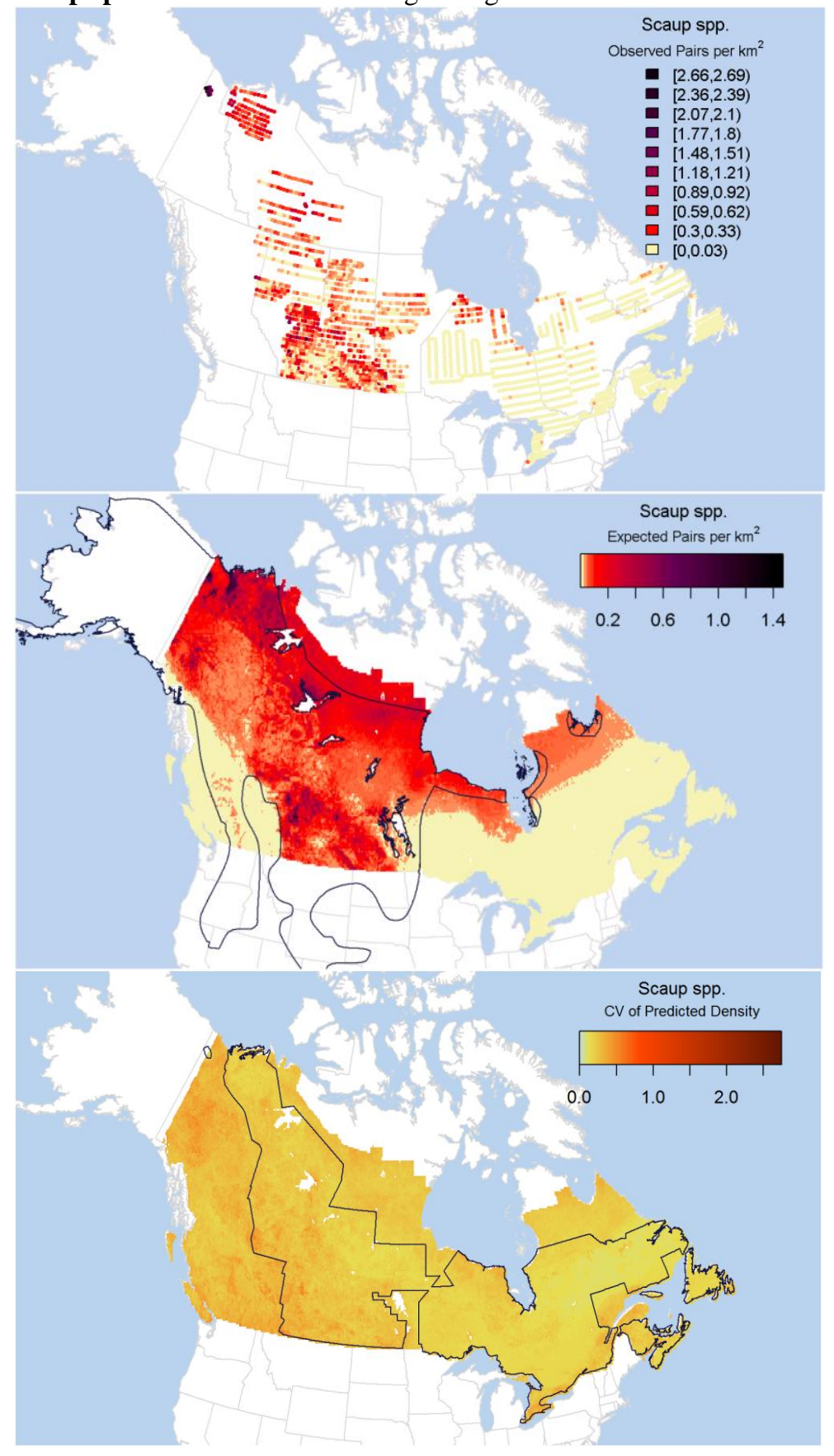

Our models predicted high scaup abundances in the northwestern prairie-parkland region, and in northwestern Canada. Since Lesser and Greater Scaup are not differentiated within the survey, these predicted densities represent a combination of both species. The relative contribution of each species at a given location is not known with any precision, but the Greater Scaup's range is reportedly more northerly than that of the Lesser 
Scaup (Johnsgard 2010). Both species reportedly use the western boreal forest, but the Lesser Scaup's range extends further south into the prairie-parkland while the Greater Scaup extends north to the treeline and also into eastern Canada (Johnsgard 2010). Our predicted densities are consistent with these published maps, with slight overpredictions in the northeastern boreal.

\begin{tabular}{|c|c|c|c|}
\hline Variable & Mean \% & SD & Cumulative $\%$ \\
\hline \% Open Water (HWL) & 10.59 & 1.42 & 10.59 \\
\hline Standard Deviation of Growing Season Length & 5.43 & 1.35 & 16.02 \\
\hline Standard Deviation of Minimum Temperature in October & 5.24 & 2.30 & 21.26 \\
\hline Density of Waterbodies (neighbourhood metric) & 3.72 & 1.00 & 24.98 \\
\hline Mean Winter Precipitation & 3.17 & 0.96 & 28.15 \\
\hline Mean Autumn Precipitation & 3.07 & 0.78 & 31.22 \\
\hline Mean Climate Moisture Index & 2.80 & 0.64 & 34.02 \\
\hline Topographic Ruggedness & 2.78 & 0.72 & 36.80 \\
\hline Precipitation Seasonality & 2.78 & 0.85 & 39.57 \\
\hline Mean Autumn Maximum Temperature & 2.50 & 1.47 & 42.07 \\
\hline Amount of Shoreline $\left(\mathrm{km} / \mathrm{km}^{2}\right)$ & 2.30 & 0.78 & 44.37 \\
\hline Standard Deviation of Minimum Temperature in September & 2.30 & 0.91 & 46.67 \\
\hline Standard Deviation of Maximum Temperature in April & 2.09 & 0.65 & 48.76 \\
\hline Standard Deviation of Maximum Temperature in January & 2.06 & 0.69 & 50.82 \\
\hline$\%$ Deciduous Forest & 1.85 & 0.56 & 52.68 \\
\hline Mean Winter Minimum Temperature & 1.73 & 1.03 & 54.40 \\
\hline$\%$ Cropland-woodland & 1.56 & 0.47 & 55.96 \\
\hline Mean Gross Primary Productivity & 1.45 & 0.53 & 57.41 \\
\hline Standard Deviation of Maximum Temperature in November & 1.36 & 0.66 & 58.78 \\
\hline Standard Deviation of Minimum Temperature in April & 1.36 & 0.67 & 60.14 \\
\hline Amount of Streams $\left(\mathrm{km} / \mathrm{km}^{2}\right)$ & 1.35 & 0.48 & 61.48 \\
\hline Standard Deviation of Precipitation in January & 1.34 & 0.32 & 62.82 \\
\hline Standard Deviation of Precipitation in April & 1.34 & 0.82 & 64.16 \\
\hline Mean Summer Precipitation & 1.28 & 0.53 & 65.44 \\
\hline Standard Deviation of Maximum Temperature in March & 1.20 & 0.27 & 66.65 \\
\hline Mean Spring Precipitation & 1.17 & 0.84 & 67.82 \\
\hline Standard Deviation of Precipitation in October & 1.15 & 0.60 & 68.98 \\
\hline Standard Deviation of Precipitation in September & 1.13 & 0.40 & 70.11 \\
\hline Standard Deviation of Minimum Temperature in May & 1.11 & 0.51 & 71.22 \\
\hline Standard Deviation of Minimum Temperature in August & 1.11 & 0.50 & 72.33 \\
\hline Standard Deviation of Maximum Temperature in September & 1.09 & 0.42 & 73.42 \\
\hline Mean Shoreline Complexity (neighbourhood metric) & 1.06 & 0.27 & 74.48 \\
\hline Standard Deviation of Maximum Temperature in December & 1.03 & 0.25 & 75.51 \\
\hline Annual Range in Temperature & 1.01 & 0.53 & 76.52 \\
\hline Mean Precipitation in the Wettest Month & 0.96 & 0.58 & 77.47 \\
\hline Standard Deviation of Precipitation in March & 0.92 & 0.41 & 78.40 \\
\hline Standard Deviation of Maximum Temperature in October & 0.92 & 0.31 & 79.32 \\
\hline Standard Deviation of Precipitation in June & 0.89 & 0.44 & 80.20 \\
\hline
\end{tabular}

Scaup abundance was most closely associated with the amount of open water, followed by inter-annual variation in growing season length and minimum October temperature, and water body density. The relatively high importance of climate variables may be related to the high abundances in the far North; many of the species 
living in boreal regions tended to be more strongly associated with climatic than land cover variables. A relationship with both open water and water body density relates to the species' associations with water, and may capture the regional variation in the nature of open water habitats as between the southern and northern limits of the combined species ranges. Greater Scaup tend to prefer open, shallow wetlands in the tundra (Johnsgard 2010) while Lesser Scaup prefer prairie marshes, semipermanent wetlands, and partially wooded wetlands (Austin et al. 1998, Johnsgard 2010). 


\section{LITERATURE CITED}

Austin, J. E., C. M. Custer, and A. D. Afton. 1998. Lesser Scaup (Aythya affinis). The Birds of North America Online. doi: 10.2173/bna.338.

Bellrose, F. C. 1980. Ducks Geese \& Swans of North America. Stackpole Books, Harrisburg, PA, USA. BirdLife International and NatureServe. 2012. Bird species distribution maps of the world. BirdLife International, Cambridge, UK, NatureServe, Arlington, USA.

Bird Studies Canada, OFO, Environment Canada, Ontario Nature, and OMNR. 2009. Atlas of the Breeding Birds of Ontario. [online] URL:http://www.birdsontario.org/atlas/index.jsp.

Brua, R. B. 2002. Ruddy Duck (Oxyura jamaicensis). The Birds of North America Online. doi: 10.2173/bna.696. Campbell, R. W., N. Dawe, I. McTaggart-Cowan, J. Cooper, G. Kaiser, and M. McNall. 1990. Birds of British Columbia, Volume 1. Nonpasserines - Introduction, Loons through Waterfowl. UBC Press, Victoria, BC, Canada.

Décarie, R., F. Morneau, D. Lambert, S. Carrière, and J.-P. L. Savard. 1995. Habitat use by brood-rearing waterfowl in subarctic Québec. Arctic 48:383-390.

Drilling, N., R. Titman, and F. Mckinney. 2002. Mallard (Anas platyrhynchos). The Birds of North America Online. doi: 10.2173/bna.658.

Dubowy, P. J. 1996. Northern Shoveler (Anas clypeata). The Birds of North America Online. doi:

10.2173/bna.217.

Eadie, J. M., M. L. Mallory, and H. G. Lumsden. 1995. Common Goldeneye (Bucephala clangula). The Birds of North America Online. doi: 10.2173/bna.170.

Eadie, J. M., J.-P. L. Savard, and M. L. Mallory. 2000. Barrow's Goldeneye (Bucephala islandica). The Birds of North America Online. doi: 10.2173/bna.548.

Gauthier, G. 1993. Bufflehead (Bucephala albeola). The Birds of North America Online. doi: 10.2173/bna.67.

Greenwood, R. J., A. B. Sargeant, D. H. Johnson, L. M. Cowardin, and T. L. Shaffer. 1995. Factors associated with duck nest success in the Prairie Pothole Region of Canada. Wildlife Monographs:3-57.

Haszard, S., and R. G. Clark. 2007. Wetland use by white-winged scoters (Melanitta fusca) in the Mackenzie Delta region. Wetlands 27:855-863. doi: 10.1672/0277-5212(2007)27[855:WUBWSM]2.0.CO;2.

Higgins, K. F. 1977. Duck nesting in intensively farmed areas of North Dakota. The Journal of Wildlife

Management 41:232-242. doi: 10.2307/3800600.

Hohman, W. L., and R. T. Eberhardt. 1998. Ring-necked Duck (Aythya collaris). The Birds of North America Online. doi: 10.2173/bna.329.

Johnsgard, P. 2010. . Waterfowl of North America, Revised Edition. University of Nebraska-Lincoln Libraries, Lincoln, NE, USA.

Johnson, D. H., and J. W. Grier. 1988. Determinants of breeding distributions of ducks. Wildlife Monographs:337.

Johnson, K. 1995. Green-winged Teal (Anas crecca). The Birds of North America Online. doi: 10.2173/bna.193.

Kaminski, R. M., and H. H. Prince. 1981. Dabbling duck and aquatic macroinvertebrate responses to manipulated wetland habitat. The Journal of Wildlife Management 45:1-15. doi: 10.2307/3807868.

Kindopp, R. 2002. Patterns of habitat use of breeding ducks and grebes in the western boreal forest. M.Sc. Thesis, University of Lethbridge, Lethbridge, AB, Canada.

Lemelin, L.-V., M. Darveau, L. Imbeau, and D. Bordage. 2010. Wetland use and selection by breeding waterbirds in the boreal forest of Quebec, Canada. Wetlands 30:321-332. doi: 10.1007/s13157-010-0024-z. Longcore, J. R., D. G. Mcauley, G. R. Hepp, and J. M. Rhymer. 2000. American Black Duck (Anas rubripes). The Birds of North America Online. doi: 10.2173/bna.481.

Mallory, M., and K. Metz. 1999. Common Merganser (Mergus merganser). The Birds of North America Online. doi: 10.2173/bna.442.

Mattsson, B. J., M. C. Runge, J. H. Devries, G. S. Boomer, J. M. Eadie, D. A. Haukos, J. P. Fleskes, D. N. Koons, W. E. Thogmartin, and R. G. Clark. 2012. A modeling framework for integrated harvest and habitat 
management of North American waterfowl: Case-study of northern pintail metapopulation dynamics. Ecological Modelling 225:146-158. doi: 10.1016/j.ecolmode1.2011.10.028.

Miller, M. R., J. Y. Takekawa, J. P. Fleskes, D. L. Orthmeyer, M. L. Casazza, and W. M. Perry. 2005. Spring migration of Northern Pintails from California's Central Valley wintering area tracked with satellite telemetry: routes, timing, and destinations. Canadian Journal of Zoology 83:1314-1332.

Moisan, G., R. I. Smith, and R. K. Martinson. 1967. The green-winged teal: Its distribution, migration, and population dynamics. U.S. Dept. of Interior, Fish and Wildlife Service, Special Scientific Report - Wildlife, No. 100 , Washington, DC, USA.

Mowbray, T. B. 2002. Canvasback (Aythya valisineria). The Birds of North America Online. doi: 10.2173/bna.659.

Naiman, R. J., C. A. Johnston, and J. C. Kelley. 1988. Alteration of North American streams by beaver. BioScience 38:753-762. doi: 10.2307/1310784.

Nummi, P., and H. Pöysä. 1997. Population and community level responses in Anas -species to patch disturbance caused by an ecosystem engineer, the beaver. Ecography 20:580-584. doi: 10.1111/j.16000587.1997.tb00426.x.

Regroupement QuébecOiseaux, le Service canadien de la faune d'Environnement Canada, and Études d'Oiseaux Canada. 2014, August 6. Atlas des oiseaux nicheurs du Québec. [online] URL:http://www.atlasoiseaux.qc.ca/index_fr.jsp.

Rempel, R. S., K. F. Abraham, T. R. Gadawski, S. Gabor, and R. Kenyon Ross. 1997. A simple wetland habitat classification for boreal forest waterfowl. The Journal of Wildlife Management 61:746-757.

Rohwer, F. C., W. P. Johnson, and E. R. Loos. 2002. Blue-winged Teal (Anas discors). The Birds of North America Online. doi: 10.2173/bna.625.

Savard, J.-P. L., D. Bordage, and A. Reed. 1998. Surf Scoter (Melanitta perspicillata). The Birds of North America Online. doi: 10.2173/bna.363.

Stewart, R. E., and H. A. Kantrud. 1973. Ecological distribution of breeding waterfowl populations in North Dakota. The Journal of Wildlife Management 37:39-50.

Toft, C. A., D. L. Trauger, and H. W. Murdy. 1982. Tests for species interactions: Breeding phenology and habitat use in subarctic ducks. The American Naturalist 120:586-613.

Woodin, M. C., and T. C. Michot. 2002. Redhead (Aythya americana). The Birds of North America Online. doi: 10.2173/bna.695. 